\title{
CLAYS AND CLAY PRODUCTS.
}

\section{PROPERTIES AND TESTS OF FULLER'S EARTH. ${ }^{a}$}

By John T. Porter.

\section{GEOLOGY AND ORIGIN.}

Practically all workable deposits of fuller's earth are of secondary origin; having been redeposited in sedimentary series. Residual deposits are also known, for example, in Saxony, where the fuller's earth is found in situ derived from gabbro. As is to be expected from its origin, the deposits are most frequently found in the Tertiary formations. Thus the well-known beds at Quincy, Fla., are of the Miocene epoch, and the earths in South Carolina belong to the Eocene and Neocene formations. The extensive deposits of South Dakota are also of Tertiary age, but in which division I am unable to state. On the other hand, certain British deposits are stated ${ }^{b}$ to belong to the lower greensand (Lower Cretaceous), and Dana ${ }^{c}$ mentions the "fuller's earth group" as a subdivision in oolite of the Jurassic period.

Gabbro, diorite, diabase, and basalt are mentioned by different writers as rocks from which fuller's earth is derived. It will be noticed that these rocks are all similar in their nature and belong to either the hornblendic or basaltic series. Their characteristic mineral constituents are the augites and hornblendes, with the feldspars less prominent; the zeolites magnetite, ilmenite, olivine, and other minerals may also be present. The subjoined table gives a list of minerals which from lithologic considerations would seem likely to be found in fuller's earth. This list embraces not only the abovementioned minerals, but also the hydrous aluminum silicates or clay minerals which may result from their decomposition. For convenience in reference, the chemical composition and certain physical properties are also tabulated.

$a$ The work on which this report is based was carried out in the laboratory and at the expense of Mr. Charles Catlett, of Staunton, Va., in connection with an investigation of the subject for private persons. Mr. Catlett has kindly placed the results of this work at the disposal of the Survey, and as they seem to represent the first detailed series of comparative tests on such materials it has been decided to publish them in the present bulletin.-E. C. E.

$b$ Nineteenth Ann. Rept. U. S Geol. Survey, pt. 6, continued, 1898, p. 408.

c Dana, J. D., Manual of Geology, 1895, p. 775. 
TABLE 1.-Minerals likely to be foundi in fuller's carth.

MINERALS OF CLAYS AND SOILS.

\begin{tabular}{|c|c|c|c|c|c|}
\hline Name. & $\begin{array}{l}\text { Specific } \\
\text { gravity. }\end{array}$ & $\begin{array}{l}\text { Fard- } \\
\text { ness. }\end{array}$ & Crystallization. & Effect of acids. & $\begin{array}{l}\text { Author- } \\
\text { ity. } a\end{array}$ \\
\hline Muscovite......... & 2.80 & 2.00 & Monoclinic & Not attacked. & $A, B$. \\
\hline Biotite. & 2.90 & 2.50 & .... do .... & & A. \\
\hline Phlogopite........ & 2.80 & 2.50 & .....do. & & A. \\
\hline Pectolite... & 2.70 & 5.00 & & Decomposed by HCl............. & A, B. \\
\hline $\begin{array}{l}\text { Laumontite........ } \\
\text { Prehnite.......... }\end{array}$ & $\ddot{2} \ddot{90}$ & 6.00 & Orthorhombic.. & 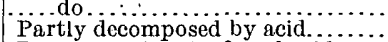 & B. $\mathrm{B}$. \\
\hline Natrolite. & 2.20 & 5.00 & .... do .......... & Decomposed by $\mathrm{H}_{2} \mathrm{O}$ and acid...... & $A, B$. \\
\hline Analcite. & 2.20 & 5.00 & Isometric. & Decomposed by $\mathrm{HICl} . . . . . \ldots \ldots$ & $\mathrm{A}, \mathrm{B}$ \\
\hline Datolite. & 3.00 & 5.00 & Monoclinic. & 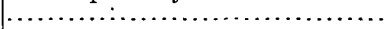 & A. \\
\hline Chabazite & 2.10 & 4. 50 & Hexagonal. & & A. \\
\hline Stilbite... & 2.10 & 3.50 & Monoclinic. & Decomposed by HCl........... & A, B. \\
\hline Heulandite & 2.20 & 3.50 & .... do ..... & $\ldots$ do ${ }_{1} \ldots \ldots \ldots \ldots \ldots \ldots \ldots \ldots \ldots \ldots$ & A, B. \\
\hline Orthocla & 2.50 & 6.00 & ...do... & Insoluble. . . . . . . . . . . . . . . . & $A, B$ \\
\hline Microcli & 2.50 & 6.00 & Triclinic. & & A. \\
\hline Albite... & $\begin{array}{l}2.60 \\
2.60\end{array}$ & 6.00 & .....do. & Not attacked $\ldots \ldots \cdots \cdots \cdots \cdots$ & $A, B$ \\
\hline $\begin{array}{l}\text { Oligoclas } \\
\text { Labrador }\end{array}$ & $\begin{array}{l}2.60 \\
2.70\end{array}$ & $\begin{array}{l}6.00 \\
5.00\end{array}$ & - ado. & 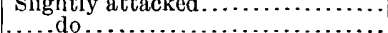 & $A, B$. \\
\hline $\begin{array}{l}\text { Labradori } \\
\text { Anorthite }\end{array}$ & 2.70 & $\begin{array}{l}0.00 \\
6.00\end{array}$ & .....do. & Decomposed by $\mathrm{HCl}$. & A. B. \\
\hline Hornblende......... & 3.10 & 6.00 & Monoclinic. & Slightly attacked.... & $\mathrm{A}, \mathrm{B}$. \\
\hline Tremolite........ & 3.00 & 6.00 & .....do.. & $\ldots$ do $\ldots . . . . .$. & $\mathrm{A}, \mathrm{B}$. \\
\hline Actinolit & 3.10 & 6.00 & $\ldots$ do. & $\ldots$ do... & $A, B$. \\
\hline Glaucophan & 3.10 & 6.00 & .....do. & $\cdots$ & \\
\hline Diallage. . & & & & I. & \\
\hline Enstatite. & 3.20 & 5.50 & Orthorhombic.. & $\ldots \ldots \ldots \ldots+$ & A. \\
\hline Hypersthene...... . & 3.50 & 6.00 & .....do... & $\cdots \ldots \ldots \ldots$ & A. \\
\hline Jefferisite.. & & & $\cdots$ & $\ldots \ldots \ldots \ldots$ & \\
\hline Ripidolite. & & & & & \\
\hline Penninite. & 3.90 & 2.00 & Monoclinic. & $\ldots \ldots \ldots \ldots \ldots$ & A. \\
\hline Prochlorite........ & 2.90 & 2.00 & .....do.... & $\cdots \cdots$ & A. \\
\hline $\begin{array}{l}\text { Spinel..... } \\
\text { Hydrargilli }\end{array}$ & 3.60 & 8.00 & $\cdots$ & and $\mathrm{H}_{2} \mathrm{SO}_{4}$ & A. \\
\hline Bauxite............. & 2.50 & 2.00 & Amorphou & $I$ and $\mathrm{H}_{2} \mathrm{SO}_{1} \ldots$ & B. \\
\hline Diaspore. & 3.40 & 7.00 & Orthorhombic.. & Insoluble in acids.............. & $A, B$. \\
\hline Quartz... & 2.60 & 7.00 & Hexag & Not attacked.... & A, B. \\
\hline Opal ... & 2.00 & 6.00 & Amorphous. & & A. \\
\hline Calcite. & 2.70 & 3.00 & Hexagonal. & Soluble. & A. \\
\hline Dolo & 2.90 & 3. 50 & $\ldots . . . d o \ldots$. & .....do... & A. \\
\hline Gyp & 1. 50 & 2.30 & Monoclin & $\ldots \ldots$ & A. \\
\hline Apatite.. & 3.20 & 5.00 & Hexa & ….......... & A. \\
\hline Marcasite......... & $=4.90$ & 6.00 & Orthorhombic.. & Insoluble...... & A. \\
\hline Pyrite.... & 5.00 & 6.00 & Isometric....... & $\ldots \ldots \ldots \ldots \ldots$ & A. \\
\hline Lim & 3. CO & 3. 00 & Am & Solu & A. \\
\hline Magnetite. & $\begin{array}{l}\text { 5. } 20 \\
5.10\end{array}$ & 6.00 & Isor & $\ldots \ldots \ldots \ldots \ldots$ & A. \\
\hline $\begin{array}{l}\text { Hema } \\
\text { Sideri }\end{array}$ & $\begin{array}{l}5.10 \\
3.80\end{array}$ & 3.00 & Hexa & 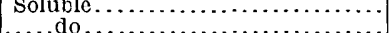 & A. \\
\hline $\begin{array}{l}\text { Slderite... } \\
\text { Rutile... }\end{array}$ & $\begin{array}{l}3.80 \\
4.20\end{array}$ & 3.50 & Tetrago & Insoluble except after long concen- & \\
\hline & 4. & 0.00 & Tetr & tration in $\mathrm{H}_{2} \mathrm{SO}_{4}$. & \\
\hline $\operatorname{Ilm}$ & 4.80 & 5.50 & Hexag & & $A$ \\
\hline Pyrolusite & 4.80 & 2.00 & Orthorhombic.. & Soluble... & \\
\hline Olivine. & 3.30 & 6. 50 & ...do... & Decomposed by $\mathrm{HCl}$ and $\mathrm{H}_{2}$ & A, B. \\
\hline Ves & 3. 40 & 6.50 & Tetrag & Partly decomposed by $\mathrm{HCl}$. & $A, B$ \\
\hline Epi & 3.30 & 6.50 & Monocli & Slightly attacked by $\mathrm{HCl}$. & A, B. \\
\hline Zois & 3.30 & 6.00 & Orthorhombic.. & Partly decomposed by $\mathrm{FCl}$. & $\mathrm{B}, \mathrm{C}$. \\
\hline Allanite & 4.00 & 5.50 & Monoclinic. & & \\
\hline Andalusite. & 3.20 & 3.00 & Orthorhombic.. & Insoluble in acids. & $A, B$. \\
\hline Staurolite. & 3.70 & 7.00 & $\ldots .$. do ......... & Not attacked.. & $A, B$ \\
\hline Fibrolite. & 3.20 & 6.00 & Triolinin & Insols 2 & \\
\hline Cyanite... & $\begin{array}{l}\text { 3. } 60 \\
2.70\end{array}$ & 6.00 & Triclinic... & Insoluble in acids & A, B. \\
\hline $\begin{array}{l}\text { Scapolite. } \\
\text { Nepheline. }\end{array}$ & 2. 60 & $\begin{array}{l}6.00 \\
6.00\end{array}$ & $\begin{array}{l}\text { Tetragonat } \\
\text { Hexoganal. }\end{array}$ & Deco & B. C. \\
\hline $\begin{array}{l}\text { Nepheline } \\
\text { Talc..... }\end{array}$ & 2.80 & 1.00 & Mono & Not attacked.. & $\mathrm{B}, \mathrm{C}$. \\
\hline Ser & 2. 60 & 3.00 & ....do. & Decomposed by acids & $\mathrm{B}, \mathrm{C}$. \\
\hline Wollastonite. & 2.90 & 4. 50 & do & Decomposed by $\mathrm{HCl}, \ldots$. & $\mathrm{B}, \mathrm{C}$. \\
\hline
\end{tabular}

$a$ A =Eakle, A. S., Mineral Tables, 1904. B=Comey, A. M., Dictionary of Solubilities. C=Dana, J. D., Manual of Mineralogy, 1857 .

Bull. $315-07-18$ 
TABLE 1.-Minerals likely to be found in fuller's earth-Continued.

CLAY MINERALS:

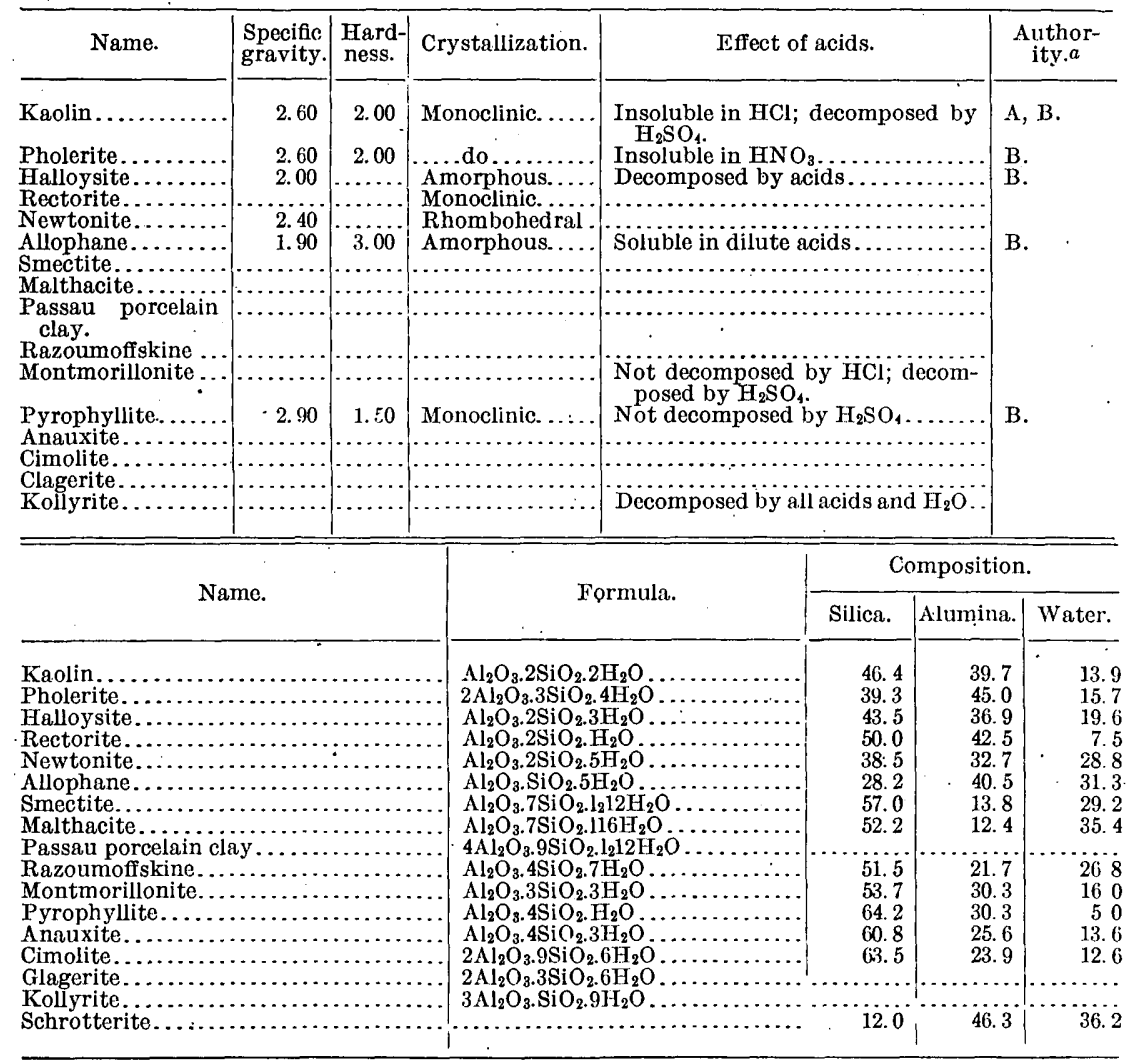

$a$ A=Eakle, A. S., Mineral Tables, 1904. B=Comey, A. M., Dictionary of Solubilities, 1896.

When the rocks from which fuller's earth is derived are kept in view, it seems to me that the inference may be fairly drawn that it results from the decomposition of the hornblendes and augites, rather than of the feldspars, as is the case with ordinary clays. This view is also supported by the fact that magnesia is almost invariably a prominent constituent of fuller's earth, in which it averages much higher than in ordinary clays. (See Table 2.)

Now, it is well known that the decomposition of the feldspars tends toward the production of kaolin and the crystalline aluminum hydrosilicates, and it seems possible that the hornblendes and augites, on the other hand, may have a tendency to decompose into the amorphous silicates. I will endeavor to show later that fuller's earth contains these amorphous aluminum hydrosilicates, and if the truth of this theory could be proved much light would be thrown on the whole question of the origin of fuller's earth and its relation to the clays.

The literature on this subject is so fragmentary and so widely distributed that references having a direct bearing on it are difficult to 
find. It is quite possible, indeed probable, however, that some of the work recently done on the action of water on rock powders ${ }^{a}$ will be found on close study to afford an explanation of the formation of fuller's earth. The following table comprises a number of analyses of fuller's earth, obtained from the sources indicated:

TABLE 2.-Analyses of fuller's earth from various sources.

[Calculated to dry state.]

\begin{tabular}{|c|c|c|c|c|c|c|c|c|c|c|c|}
\hline No. & Locality. & $\mathrm{SiO}_{2}$ & $\mathrm{Al}_{2} \mathrm{O}_{3}$ & $\mathrm{H}_{2} \mathrm{O}$ & $\mathrm{Fe}_{2} \mathrm{O}_{3}$ & $\mathrm{CaO}$. & MgO. & $\begin{array}{l}\text { Alka- } \\
\text { lics. }\end{array}$ & $\begin{array}{l}\text { Other elc- } \\
\text { ments. }\end{array}$ & Total. & $\begin{array}{l}\text { Au- } \\
\text { thor- } \\
\text { ity.a }\end{array}$ \\
\hline $\begin{array}{l}1 \\
2\end{array}$ & $\begin{array}{l}\text { Arkansas...... } \\
\ldots . . \text { do......... }\end{array}$ & $\begin{array}{l}64.38 \\
63.19\end{array}$ & $\begin{array}{l}17.29 \\
18.76\end{array}$ & $\begin{array}{l}6.95 \\
7.57\end{array}$ & $\begin{array}{l}8.27 \\
7.05\end{array}$ & \multicolumn{2}{|c|}{$\begin{array}{l}\text { 1. } 91 \\
\text { 2. } 46\end{array}$} & $\begin{array}{l}1.83 \\
1.71\end{array}$ & $\begin{array}{l}\text { n. d. } \\
\text { n. d. }\end{array}$ & $\left|\begin{array}{l}100.63 \\
100.74\end{array}\right|$ & $\Lambda$. \\
\hline 3 & Ocala, Fla & 39.66 & 30.00 & 13. 11 & 3.46 & 0.87 & 0.70 & .45 & $\left\{\begin{array}{r}\mathrm{FiO}_{2} \\
\mathrm{FiO}_{2} .37 \\
\text { Organic } 3.90\end{array}\right\}$ & 99.52 & B. \\
\hline 4 & Gadsden, Fla & 67.31 & 11.07 & 8. 25 & 2.61 & 2.60 & 3.32 & 1.01 & n. d. & 96.17 & C. \\
\hline 5 & Mount Pleasant, Fla. & 62.27 & 11.76 & 10.00 & 7.43 & 1.89 & 3.59 & n. d. & n. d. & 96.94 & c. \\
\hline 6 & Norway, Fla.. & 59.02 & 11.88 & 11.13 & 7. 14 & 6. 48 & 3.24 & n. d. & n. d. & 98.89 & c. \\
\hline 7 & River Junction, Fla. & 55.05 & 22.88 & 10.42 & 7. 47 & 4. 77 & .43 & n. d. & n. d. & 100.92 & c. \\
\hline 8 & Decatur, Ga.. & 72.00 & 10.76 & 6.00 & 2.65 & 3.34 & 4. 36 & n. d. & n. d. & 99.11 & C. \\
\hline 9 & $\left\{\begin{array}{l}\text { Enid, Okla. (glacial- } \\
\text { ite) }\end{array}\right.$ & 50.36 & 33.38 & 12.00 & 3. 31 & & & .88 & $\begin{array}{r}\mathrm{TiO}_{2} \text { tr. } \\
\text { rganic tr. }\end{array}$ & 99.93 & $D$. \\
\hline 10 & Custer, S. Dak. . & 57.00 & 17. 37 & 9.50 & 2.36 & 3.00 & 3. 03 & n. d. & Volatile 5.85 & 98.11 & $\mathrm{E}$ \\
\hline 11 & .....do & 63.50 & 14.97 & 10.70 & 4. 48 & 2.40 & 2.88 & $8.32 \mid$ & n. d. & 107.25 & D. \\
\hline 12 & 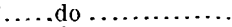 & 71.28 & 14. 33 & 4. 20 & 2. 48 & .33 & 1.20 & n. d. & n. d. & 93.92 & D. \\
\hline 13 & 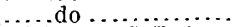 & 55.45 & 18. 58 & 8.80 & 3.82 & 3. 40 & 3.50 & n. d. & Volatile 5.35 & 98.90 & E. \\
\hline 14 & Fairburn, S. Dak & 68.23 & 14.93 & 6. 20 & 2.15 & 2. 93 & .87 & n. d. & n. d. & 96.31 & E. \\
\hline 15 & $\ldots . . d$ & 60.16 & 10.38 & 7. 20 & 14.87 & 4.90 & 1.71 & n. d. & n. $d$. & 99.28 & E. \\
\hline 16 & ....d & 67.00 & 5.00 & 15.00 & 12.00 & n. d. & n. d. & n. d. & n. d. & 99.00 & $\mathrm{D}$ \\
\hline 17 & $\ldots . . d$ & 56.18 & 23.23 & 11. 45 & 1.26 & 5.88 & 3.29 & n. d. & n. d. & 101.29 & E. \\
\hline 18 & $d$ & 60.10 & 17.30 & 8.29 & 4: 10 & 4. 16 & 2.61 & 2.16 & n. d. & 98.72 & C. \\
\hline 19 & Hermosa, S. Dak.. & 55. 40 & 27.70 & 13.00 & 1.80 & 2. 30 & .70 & 1.08 & n. d. & 101.98 & D. \\
\hline 20 & England........ & 44.00 & 23.06 & 24.95 & 2. 00 & 4. 08 & 2.00 & n. d. & n. d. & 100.09 & C. \\
\hline 21 & ..... do $\ldots$...... & 44.00 & 11.00 & n. d. & 10.00 & 5.00 & 2.00 & 5.00 & n. d. & 77.00 & C. \\
\hline 22 & $\left\{\begin{array}{c}\text { Nutfield, England } \\
\text { (blue earth). }\end{array}\right.$ & $\delta \mathrm{l}$ & 6.92 & 14. 27 & 3.78 & 7. 40 & 2. 27 & 1.74 & $\left.\begin{array}{r}\mathrm{P}_{2} \mathrm{O}_{5} \cdot 27 \\
\mathrm{SO}_{3} \cdot 05 \\
\mathrm{NaCl} \cdot 05\end{array}\right\}$ & 88.56 & D. \\
\hline 23 & $\left\{\begin{array}{c}\text { Nutfield, England } \\
\text { (yellow e.urth) }\end{array}\right.$ & 59.3 & 11.82 & $13: 19$ & 6.27 & 6. 17 & 2.09 & 1.84 & $\begin{array}{r}\mathrm{J}_{2} \mathrm{O}_{5} \cdot 14 \\
\mathrm{SO}_{3} .07 \\
\mathrm{SaCl}\end{array}$ & 100.10 & D. \\
\hline 24 & Reigate, England. & 53.00 & 10.00 & 24.00 & 9.7 & .50 & 1.25 & n. d. & n. d. & 98.50 & c. \\
\hline 25 & $\begin{array}{l}\text { Woburn sands, Eng- } \\
\text { land (yellow earth) }\end{array}$ & r. & 19. 16 & 6.75 & 11.7 & 3. 10 & 3.71 & n. d. & n. d. & 99.98 & B. \\
\hline 20 & $\begin{array}{l}\text { Woburn sands, Eng- } \\
\text { land (blue earth). }\end{array}$ & 60.90 & 18.34 & 4. 89 & 10.22 & 2.36 & 1.52 & 1.72 & n, d. & 99.95 & B. \\
\hline
\end{tabular}

$a A=$ Branner, J. C., Cement materials of southwest Arkansas: Trans. Am. Inst. Min. Eng., vol. 27, 1898 , pp. 42-63.

$\mathrm{B}=$ Nineteenth. Ann, Rept. U. S. Geol. Survey, pt. 6, continued, 1898, pp. 655-650.

$\mathrm{C}=$ Seventeenth $\Lambda$ nn. Rept. U. S. Geol. Survey, pt. 3, continued, 1896, pp. 876-880.

$\mathrm{D}=$ Eighteenth Ann. Rept. U. S. Geol. Survey, pt. 5, continued, 1897, pp. 1351-1359.

$\mathrm{E}=$ Ries, H., fuller's earth of South Dakota: 'Trans. Am. Inst. Min. Eng., vol. 27, 1898, pp. 333-335.

\section{TESTS BEARING ON THE NATURE OF FULLER'S EARTH.}

ANALYSES.

The analyses made in the course of this investigation have for convenience been grouped together and will be found in Table 3. A few results have been calculated or estimated, and the figures so derived are marked with a small c. The analyses were made by the customary methods, which hardly need explanation. All results were calculated to a dry basis. $\mathrm{CO}_{2}$ was determined gravimetrically. Combined water is ignition minus $\mathrm{CO}_{z}$, and possibly includes a little organic carbonaceous matter. 
TABLE 3.-Analyses of fuller's earth, clay, and pipe clay.

CALCULATED TO 100 PER CENT.

\begin{tabular}{|c|c|c|c|c|c|c|c|c|c|}
\hline & $\mathrm{SiO}_{2}$ & $\mathrm{Al}_{2} \mathrm{O}_{3}$ & $\mathrm{Fe}_{2} \mathrm{O}_{3}$ & $\mathrm{CaO}$. & $\mathrm{MgO}$ & $\mathrm{CO}_{2}$ & $\mathrm{H}_{2} \mathrm{O}$ & $\mathrm{P}_{2} \mathrm{O}_{5}$ & Total. \\
\hline \multicolumn{10}{|l|}{ Owl fuller's earth: $a$} \\
\hline Original earth.. & 48.20 & 17.80 & 2.09 & 10.84 & 3.33 & 7.93 & 8.91 & 1.20 & 100 \\
\hline Insoluble in dilute $\mathrm{HCl}$. & 74.20 & 12.00 & 1.94 & c. 0.5 & n.d. & & 9.28 & n. d. & 90.37 \\
\hline Insoluble in dilute $\mathrm{HCl}$ and $\mathrm{NaOH}$... & 70.70 & $15: 80$ & 1.70 & .08 & n.d. & & 9.36 & n.d. & 97.64 \\
\hline Insoluble in dilute $\mathrm{HCl}$ and soluble & & & & & & & & & \\
\hline $\mathrm{H} \ldots \ldots \ldots \ldots \ldots \ldots \ldots$ & 79.72 & 10.52 & Tr. & & n.d. & & 9.58 & n. d. & 99.82 \\
\hline Insoluble in concentrated $\mathrm{HCl}$. & 90.88 & 3.40 & & c. 05 & & & 5.14 & n.d. & 99.47 \\
\hline Insoluble in $\mathrm{H}_{2} \mathrm{SO}_{4}$ and $\mathrm{NaOH}$. & 91.10 & 4.35 & 1.09 & 3.46 & & & & n. d. & 100 \\
\hline Insoluble in $\mathrm{H}_{2} \mathrm{SO}_{4}$ and soluble in & & & & & & & & & \\
\hline 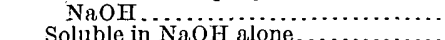 & 83.17 & 2.81 & & 14.02 & & & & n. d. & 100 \\
\hline \multirow{2}{*}{\multicolumn{10}{|c|}{ Fairbank fuller's earth: $b$}} \\
\hline & & & & & & & & & \\
\hline Original earth $\ldots \ldots \ldots$ & 59.41 & 19.90 & 7.14 & 3.29 & 2.90 & .04 & 6.75 & .06 & 99.29 \\
\hline Insoluble in dilute $\mathrm{HCl} \ldots \ldots \ldots \ldots \ldots$ & 66.60 & 19.20 & 5.54 & .48 & 1.67 & & 7.11 & n. d. & 100 \\
\hline $\begin{array}{l}\text { Insoluble in dilute } \mathrm{HCl} \text { and soluble } \\
\text { in NaOH. . . . . . }\end{array}$ & 18.80 & n.d. & n.d. & n.d. & n.d. & & n. d. & n. d. & n. d. \\
\hline n concentrated $\mathrm{HCl}$. & 86.80 & 5.95 & .90 & .27 & c. 27 & & 4.55 & n. d. & c 98.74 \\
\hline $\mathrm{II}_{2} \mathrm{SO}_{4} \ldots$ & 92.95 & 3.66 & 1.83 & n. d. & n.d. & & n.d. & n. d. & 98.44 \\
\hline $\mathrm{H}_{2} \mathrm{SO}_{4}$ an & 75.75 & 13.79 & 1.67 & c. 80 & n.d. & & n.d. & n.d. & 92.01 \\
\hline Soluble in $\mathrm{NaOH}$ alone. & 11.89 & n.d. & n. d. & n. d. & n. d. & & n. d. & n. d. & n. d. \\
\hline \multicolumn{10}{|l|}{ Fimer \& Amend fuller's earth: $c$} \\
\hline Original earth. & 60.20 & 21.00 & 7.80 & 2.80 & 2.60 & n.d. & 7.50 & n.d. & 99.10 \\
\hline concentrated $\mathbf{H}$ & 75.30 & 17.20 & 5.04 & $\mathrm{Tr}$. & 2.46 & & n. d. & n.d. & 100 \\
\hline $\mathrm{H}_{2} \mathrm{SO}_{4} \ldots$ & 91.95 & 3.67 & Tr. & .61 & .76 & & 3.67 & n.d. & 100.66 \\
\hline Insoluble in $\mathrm{H}_{2} \mathrm{SO}_{4}$ and $\mathrm{NaOH}$. & 73.06 & 12.00 & & 5.44 & n.d. & & n.d. & n.d. & 90.50 \\
\hline \multicolumn{10}{|l|}{ Clay: $d$} \\
\hline As red & 61.62 & 22.82 & 4 & .52 & n.d. & n.d. & 8.06 & n. d. & 97.02 \\
\hline $\begin{array}{l}\text { Insoluble. } \\
\text { ipe clay: } c\end{array}$ & 92.48 & . 3.53 & & .14 & n.d. & n.d. & n.d. & n. d. & 96.01 \\
\hline As I & 46.10 & & & & & n.d. & 12.82 & n. d. & 99.92 \\
\hline Insoluble in $\mathrm{H}_{2} \mathrm{~S}$ & 97.06 & 2.94 & & & & n.d. & n.d. & n.d. & 100 \\
\hline
\end{tabular}

PER CENT OF ORIGINAL EARTH.

Owl fuller's earth: $a$

Original enrth...

Insoluble in dilute $\mathrm{HCl}$

Insoluble in dilute $\mathrm{HCl}$ and $\mathrm{N} \Omega \mathrm{OH}$

Insoluble in dilute $\mathrm{HCl}$ and soluble in $\mathrm{NaOH}$

Insoluble in concentrated H.

Insoluble in concentrated $\mathrm{HCl}$ and

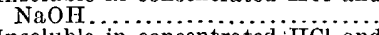
Insoluble in concentrated HCl and

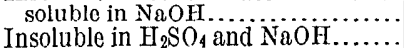
Insoluble in $\mathrm{H}_{2} \mathrm{SO}_{4}$ and soluble in

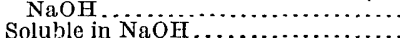

Fairbank fuller's earth: $b$

Original earth

Insoluble in dilute $\mathrm{H}$.

Insoluble in dilute $\mathrm{HCl}$ and soluble

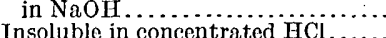

Insoluble in concentrated $\mathrm{HCl}$ and soluble in NaOH.

Insoluble in $\mathrm{H}_{2} \mathrm{SO}_{4} \ldots \ldots \ldots \ldots \ldots \ldots \ldots \ldots$

Insoluble in $\mathrm{H}_{2} \mathrm{SO}_{4}$ and $\mathrm{NaOH}$........

Soluble in $\mathrm{NaOH} . . . . . . . . . . . . .$.

Eimer \& Amend fuller's earth: $c$

Original earth...............

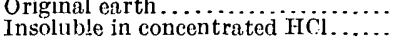

Insoluble in $\mathrm{H}_{2} \mathrm{SO}_{4} \ldots \ldots \ldots \ldots \ldots$

Insoluble in $\mathrm{H}_{2} \mathrm{SO}_{4}$ and $\mathrm{NaOH} . . . .$.

Soluble in $\mathrm{NaOH} \ldots \ldots \ldots \ldots \ldots \ldots \ldots$
Soluble in $\mathrm{Na}_{2} \mathrm{CO}_{3} \ldots \ldots \ldots \ldots \ldots \ldots$ Clay: $d$

As received

Insoluble in $\mathrm{H}_{2} \mathrm{~s}_{4} \ldots \ldots \ldots \ldots \ldots \ldots$

Soluble in $\mathrm{Na}_{2} \mathrm{CO}_{3} \ldots \ldots \ldots$

Pipe clay:

As received

Insoluble in $\mathrm{Fi}_{2} \mathrm{~S} \mathrm{O}$

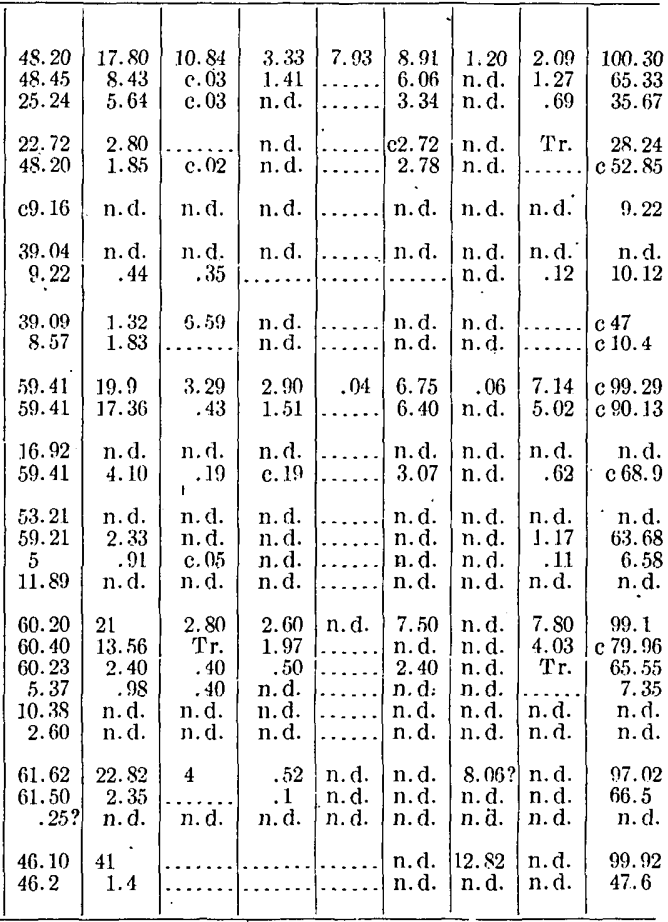

$a$ Sample from Owl Cigar Co., Quincy, Fla.

$b$ Sample from N. K. Fairbank Co., Chicago, Ill.

c Sample from Eimer \& Amend, New York, N. Y.

$d$ Residual limestone clay from Staunton, Va. 
PHYSICAI TESTS.

Plasticity is defined as that property which permits clay to be molded in any desired form when wet, the shape being retained when dry. ${ }^{a}$ F. F. Grout ${ }^{b}$ says that "Plasticity may be considered as involving two variable factors-(1) amount of possible flow before rupture; (2) resistance to flow or deformation."

According to either of these definitions the four samples of fuller's earth which I have tested are most decidedly plastic, in spite of the fact that nonplasticity is given as one of the distinguishing qualities of this material by almost every writer on the subject.

In making these tests small pats of wet earth were allowed to air dry, and portions were heated to redness to note their behavior. It was found that the fuller's earths require much water to bring them to the plastic state, apparently more than the kaolin, although the quantity used was not measured. The fuller's earth also formed a much more sticky mass than the other materials tried; and had a more soapy or greasy feel. Table 4 gives the results of these tests in convenient form.

TABLe 4.-Physical properties of fuller's earths, etc.

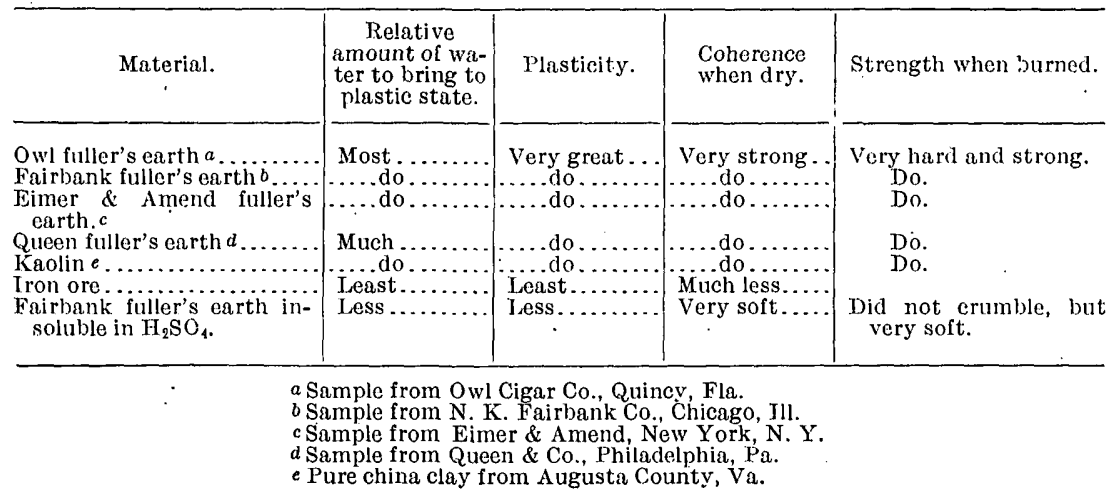

OIL TESTS.

In making the oil tests $50 \mathrm{c}$. c. of cotton-seed oil were introduced into a stout comparison tube of about 120 c. c. capacity. This was then placed in an oil bath and heated to a temperature of $220^{\circ} \mathrm{F}$.; 2.5 grams of the earth to be tested were then poured into the tube, which was at once removed from the oil bath, closed with a rubber stopper, and shaken for five minutes. At the end of this time the contents were poured into a creased filter in a hot-water funnel, and the filtered oil was received in a tube protected from the light by a cardboard case. This protection was found necessary because certain

$a$ Ries, H., Clays and clay industries of New Jersey: Final Repts. New Jersey Geol. Survey, vol. 6 , 1904, p. 81 .

$b$ Clays, Linies, and Cements, West Virginia Geol. Survey, 1906, p. 41. 
oil samples bleached out very rapidly after treatment if exposed to light, and the amount of bleaching varied in different samples. The method of comparison adopted was as follows: Twenty-one samples of oil were selected which had stood in the light long enough to have reached a condition of stability, and which showed a progressive range of color from the lightest to the darkest oil on hand. These samples were contained in glass vials of uniform size, were kept in a dark box, and were numbered from 1 to 21, No. 1 being Fairbank's standard white oil, which had stood in the light several years and No. 21 Fairbank's crude yellow oil, kept in the dark so that it had not lost any of its depth of color. The samples tested were then placed in similar vials, compared with the standards against a sheet of white paper, and the number of the standard most nearly agreeing with it in shade was taken as its color value. This comparison was always made immediately after filtration, before the oil had been exposed to light. After standing over night in the dark the sample was compared again, and a third time after standing in the light for two weeks. This method of comparison proved very satisfactory, and there was no evidence of any change in the standards on keeping. The only weakness of the method lies in the fact that the members of the color series do not vary uniformly in the amount of color contained, and hence these comparisons can give no information as to the absolute percentage of color removed.

The results of the oil tests are grouped in Table 5, which does not include, however, a number of the first tests that were considered unreliable. It should be noted that standards Nos. 19, 20, and 21 are all crude yellow oils untreated, and that no bleaching action is indicated with any certainty unless the color of the treated sample falls to 18 or less.

'ТАВLE 5.-Results of oil tests of fuller's earth and other materials.

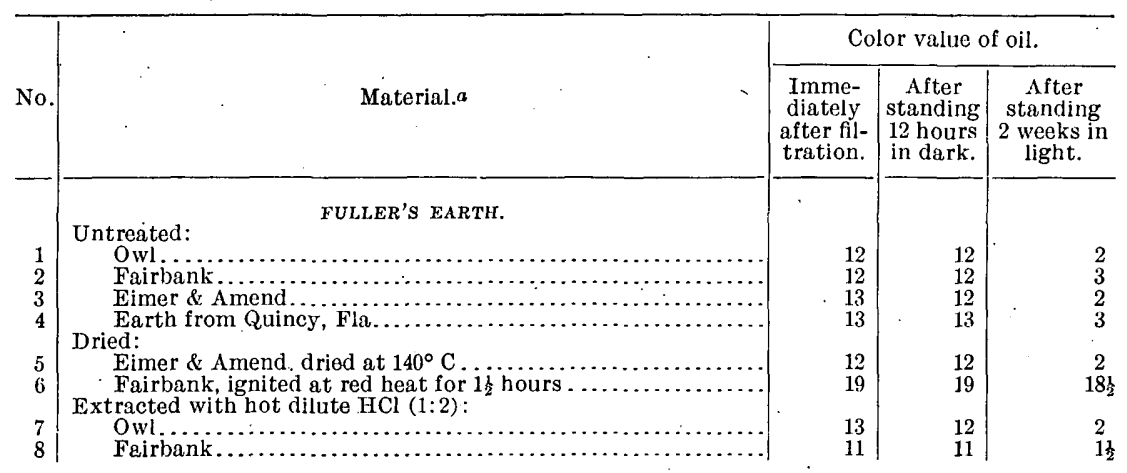

a Fuller's earths: Owl, from Owl Cigar Co., Quincy, Fla.; Fairbank, earth at present used by N. K. Fairbank Co., Chicago, Ill., received in June, 1906; Eimer \& Amend, from Eimer \& Amend, New York,

N. Y. Pipe clay (sample from Eimer \& Amend), nearly pure kaolinite, as shown by the rational analysis-kaolin, 91.51 ; orthoclase, 7.61 ; quartz, 0.88 - which is calculated from the analysis given in Table 3 . Clay, a residual limestone clay from a bank in Staunton, Va. Analyses of most of these materials will be found in Table 3 (p. 272). 
TABLE 5.-Results of oil tests of fuller's earth and other materials-Continued.

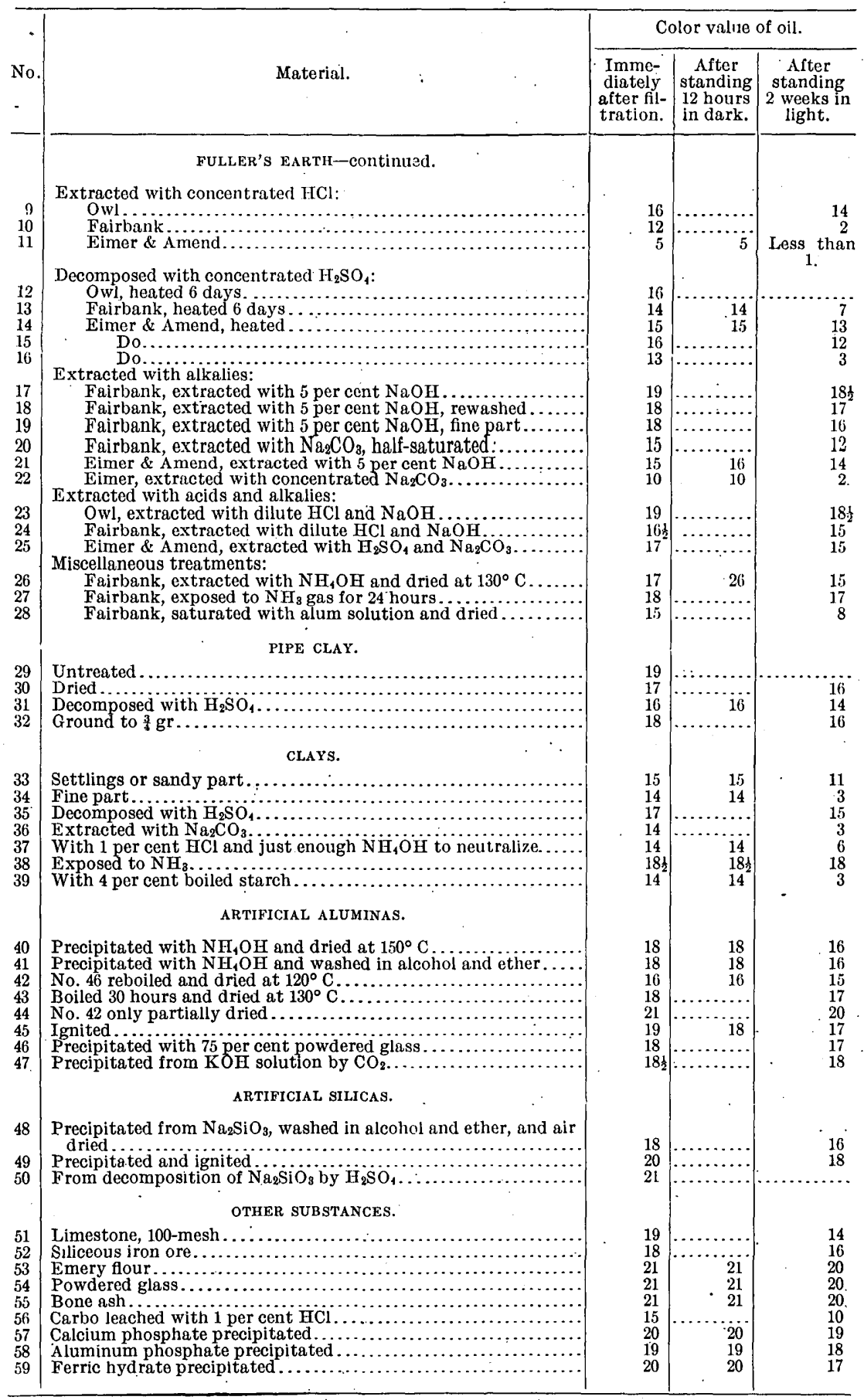




\section{NATURE OF FULLER'S EARTH.}

\section{THEORIES OF OTHER WRITERS.}

Almost as many suggestions have been advanced concerning the nature of fuller's earth as there are writers on the subject, but apparently none of them are based on anything more than an inspection of the ultimate analyses. I will now take up these theories and study them in the light of my experiments.

Dana $^{a}$ states that fuller's earth has for its base the mineral smectite, and possibly also malthacite. Although it is not so stated in the passage quoted, the inference is that he considers these minerals the cause of the bleaching power. In order to test the truth of this theory it is necessary to have at hand formulæ of smectite and malthacite, and these I have calculated as here described. Dana (as quoted by $\operatorname{Ries}^{a}$ ) gives the following analyses of impure minerals:

Analyses of smectite and malthacite.

\begin{tabular}{|c|c|c|c|c|c|c|}
\hline & $\mathrm{SiO}_{2}$ & $\mathrm{Al}_{2} \mathrm{O}_{3}$ & $\mathrm{H}_{2} \mathrm{O}$ & $\mathrm{Fe}_{2} \mathrm{O}_{3}$ & $\mathrm{CaO}$. & MgO. \\
\hline 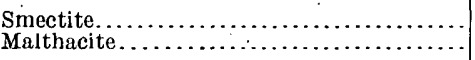 & $\begin{array}{l}51.21 \\
50.17\end{array}$ & $\begin{array}{l}12.25 \\
10.66\end{array}$ & $\begin{array}{l}27.89 \\
35.83\end{array}$ & $\begin{array}{l}2.07 \\
3.15\end{array}$ & $\begin{array}{r}2.13 \\
.25\end{array}$ & 4.89 \\
\hline
\end{tabular}

I have considered the iron, lime, and magnesia as impurities, and have recalculated the analysis on the basis of silica, alumina, and water $=100$. The result is as follows:

Recalculated analyses of smectite and malthacite.

\begin{tabular}{|c|c|c|c|}
\hline & $\mathrm{SiO}_{2}$ & $\mathrm{Al}_{2} \mathrm{O}_{3}$ & $\mathrm{H}_{2} \mathrm{O}$ \\
\hline $\begin{array}{l}\text { Smectite... } \\
\text { Malthacite. }\end{array}$ & $\begin{array}{l}56.0 \\
51.9\end{array}$ & $\begin{array}{l}13.5 \\
11.0\end{array}$ & $\begin{array}{l}30.5 \\
37.1\end{array}$ \\
\hline
\end{tabular}

The formulæ corresponding most nearly to these figures are for smectite $\mathrm{Al}_{2} \mathrm{O}_{3} \cdot 7 \mathrm{SiO}_{2} \cdot 12 \mathrm{H}_{2} \mathrm{O}$, and for malthacite $\mathrm{Al}_{2} \mathrm{O}_{3} \cdot 7 \mathrm{SiO}_{2} \cdot 16 \mathrm{H}_{2} \mathrm{O}$, and the percentage composition for these formulæ should be the following:

Composition corresponding to formula for smectite and malthacite.

\begin{tabular}{|c|c|c|c|}
\hline . & $\mathrm{SiO}_{2}$ & $\mathrm{Al}_{2} \mathrm{O}_{3}$ & $\mathrm{H}_{2} \mathrm{O}$ \\
\hline 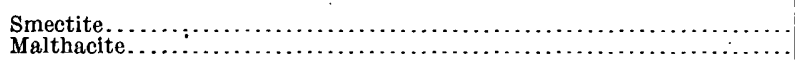 & $\begin{array}{l}57.06 \\
52.18\end{array}$ & $\begin{array}{l}13.78 \\
12.40\end{array}$ & $\begin{array}{l}29.16 \\
35.42\end{array}$ \\
\hline
\end{tabular}

These figures are used in all calculations and in the table of minerals (p. 270). 
To return now to Dana's theory of fuller's earth, it is evident that it will not stand since the discovery of American deposits having a comparatively low percentage of combined water. Such earths could not possibly have as their base either smectite or malthacite, although they might contain very small quantities of these minerals. For example, take analysis 18 of Table 2 (p. 271), representing a sample of earth from Fairburn, S. Dak. Calculating the water in this entirely to smectite gives 28.1 per cent smectite, requiring 16 per cent silica and 3.8 per cent alumina, and leaving a large balance of silica and alumina, as well as impurities, to be calculated to anhydrous minerals.

Again, my analyses of Fairbank and Owl fuller's earths (Table 3, p. 272) show that it is utterly impossible for these earths to contain even moderate amounts of smectite or malthacite, in view of the small quantities of quartz and undecomposible anhydrous silicates shown. This point is very clearly brought out when the calculation of a rational composition is attempted. Another point which argues against the presence of smectite and malthacite in American fuller's earths is the fact that these earths retain much and in some cases all of their efficiency after treatment with strong acids. Although I have not been able to find any statement that smectite and malthacite are decomposed by sulphuric acid, still it is very probable that they are so attacked, owing to their large percentage of combined water.

It is interesting to note in passing that an inspection of the table of minerals shows that where determined the ease of decomposition by acids of the hydrous aluminum silicates is probably a direct function. of the percentage of alumina and combined water, the water probably having the greater effect.

Although it may be regarded as settled that smectite and malthacite are not contained to any extent in most American fuller's earths, and hence are not essential to the bleaching power, still it is probably true that smectite forms the basis of many foreign earths. It is of course impossible to calculate rational composition with any certainty from ultimate analysis alone. However, the following composition has been calculated from analysis 24 of Table 2 (p. 271), principally to show the possibility that this earth contains smectite as a base:

Rational analysis of fuller's earth from Reigale, England.

\begin{tabular}{|c|c|c|c|c|c|c|}
\hline & Total. & $\mathrm{SiO}_{2}$ & $\mathrm{Al}_{2} \mathrm{O}_{3}$ & $\mathrm{I}_{2} \mathrm{O}$ & $\mathrm{Fe}_{2} \mathrm{O}_{3}$ & $\begin{array}{l}\text { Alkalies, } \\
\mathrm{CaO} \text { and } \\
\mathrm{MgO} \text {. }\end{array}$ \\
\hline 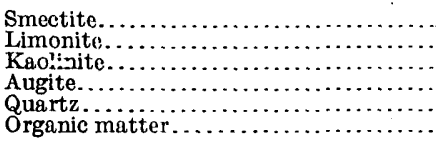 & $\begin{array}{r}70 \\
12.6 \\
1.6 \\
6.5 \\
8.9 \\
.4\end{array}$ & 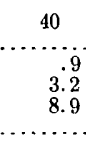 & $\begin{array}{l}9.6 \\
\cdots .4\end{array}$ & $\begin{array}{r}20.4 \\
2.9 \\
.3 \\
+. \\
.4\end{array}$ & 9.7 & 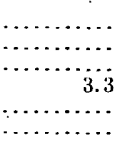 \\
\hline
\end{tabular}


Ries ${ }^{a}$ states that fuller's earth probably contains much hydrous silica, the inference being that it is this constituent which gives it its distinctive qualities. A somewhat similar inference is perhaps to be drawn from the following quotation, referring to the Florida and Georgia earths: $b$

This leads to the hypothesis that this earth probably originated in ordinary clay, which has received from interfiltering solutions an additional supply of silicic acid, which sometimes combined with the clay and occasionally was deposited as chert.

My analyses have confirmed Ries's statement that fuller's earth contains appreciable amounts of hydrous silica. (See Table 3, p. 272.) However, it is evident that if the bleaching power of fuller's earth is due to this hydrous silica, treatment of the earth with boiling carbonate or hydrate of soda, which removes the silica, should destroy this bleaching power. I have tried this experiment on several earths, and the result will be found in Table 5 (p. 275). It will be seen at once that although the results are not entirely concordant, yet there can be no doubt that fuller's earth retains at least a part of its efficiency after treatment by alkalies. It is also plain that carbonate of soda has a much less harmful action on the earth than the hydrate. As Fresenius and other authorities state that hydrous and amorphous silica are freely soluble in hot carbonate of soda, as well as in sodium hydrate; this difference can hardly be due to nonsolution of the silica by the carbonate, but is almost entirely due to partial decomposition of the earth by sodium hydrate. In this connection, I have noticed that sodium hydrate appears to extract considerable alumina as well as silica, but the carbonate does not. Fuller's earth after treatment with sodium hydrate is left in a very gelatinous condition and is extremely hard to filter and wash. For this reason it is possible that some of the samples treated retained considerable amounts of soluble salts after washing, although great pains were taken to remove them, and this may have had some influence on the results.

Another fact which might be used as an argument against this theory is that hydrous silica artificially prepared has but very slight bleaching powers. (See Table 5.) These results are naturally not conclusive, as the silicic acid occurring naturally may differ either physically or chemically, or both, from the artificial product.

On the other hand, some earths still retain a considerable portion of their bleaching power after decomposition by acids, consisting then of 80 per cent or more of silica; and from this it seems probable that hydrous silica when prepared in certain ways may have some small efficiency.

In conclusion, I think I am justified in stating, first, that hydrous silica does not of itself possess bleaching power, although it may at

a Ries, H., Fuller's earth of South Dakota: Trans. Am. Inst. Min. Eng., vol. 27, 1898, p. 333.

3 Twenty-first Ann. Rept. U. S. Geol. Survey, pt. 6, continued, 1901, p. 591. 
times possess some efficiency as a result of existing in a certain physical condition; and, second, that it is certain that fuller's earth can not owe more than a small part of its peculiar properties to the presence of free silicic acid.

Sloan ${ }^{a}$ makes the following suggestion concerning the mode of action of fuller's earth:

Fuller's earth is now extensively employed in the bleaching of mineral, animal, and vegetable oils and fats. The alleged chemical bleaching in the process is highly questionable; its action more properly involves mechanical entanglement of the suspended coloring matter by the contained clay substance. * * * It is observed that where the alumina exceeds one-fifth of the amount of silica present the critical point is approximated beyond which an increase in the densely bedding aluminous matter prejudices filtration. The silica therefore serves to maintain the required porosity.

Sloan has here come very near to hitting the mark. He has evidently the right idea in mind, but has not gone deeply enough into the subject to state it in detail with clearness. The propriety of these remarks will become more clearly apparent later in this discussion; for the present I will only remark that it is important that the term "clay substance" be taken in its more general significance and not as synonymous with kaolin. Also, I must take exception to the implied statement that the bleaching power is dependent on and proportional to the alumina in the earth, as I have found that up to a certain point removal of the alumina is actually beneficial to the efficiency of the earth. (See results 8, 10, and 11, Table 5.)

I see no other suggestions as to the mode of action of fuller's earth proposed in any of the literature, but it is possible' that some may consider extreme fineness of grain an explanation, and it may be worth while to combat this idea. Wheeler, I believe, has shown that most clays (and other minerals?) have some slight bleaching power, if very finely powdered, but no one has been able to procure any appreciable efficiency by such means. The few experiments I have made have given practically negative results, and, as shown later, any very slight increase in efficiency can be readily. explained. Finally, it can be easily seen that it would be very difficult to explain the peculiar effects of acid on fuller's earth on the assumption that its bleaching action is due primarily to fineness.

In concluding this division the following quotation ${ }^{b}$ seems of interest. The authors are chemists of the United States Internal-Revenue Office and undoubtedly have excellent facilities for consulting chemical literature.

The color-absorbing power of fuller's earth is a most interesting subject which does not appear to have been investigated to any extent. Whether it is due to chemical or physical action, and the connection, if any, between the composition of the earth

a Sloan, Earle, Preliminary Report on Clays of South Carolina, South Carolina Geol. Survey, 1904, pp. 59-61.

$b$ Crampton, C. A., and Simons, F. D., Detection of caramel in spirits and vinegar: Jour Am. Chem. Soc., vol. 21, 1899, p. 355. 
(which seems to be anything but uniform) and its effect upon various coloring matters should receive attention and would doubtless yield interesting and valuable results to investigation. If any work has been done along this line, no results have been published, as the journals make little or no mention even of the fact that fuller's earth possesses such properties.

\section{COLLOIDS AND PECTOIDS.}

\section{A colloid is defined ${ }^{a}$ as referring generally-}

to those bodies which pass into solution in water, but which will not while in solution pass through a parchment diaphragm, as substances in true molecular solution always will do. The word hydrogel given by Graham is used to refer to the jellied colloids as they originally coagulate from the hydrosols. * * * Ostwald says: "Colloidal substances exist in two modifications-the soluble and the coagulated or "pectinized." We need another word to express this latter condition, and the word pectoid is truer to the Greek root.( $\pi \eta \kappa \tau o ́ s)$ than pectinized.

A little later on I shall endeavor to show that the peculiar properties of fuller's earth are probably due to the presence of a group of aluminum hydrosilicates existing in the form of pectoids, as above defined, and with this object in view I will now give a short digest of the present knowledge of colloidal substances as far as I have been able to find it in the literature at my command.

Colloids and also pectoids exist among both organic and inorganic substances, ferric and aluminum hydroxides being familiar examples of the latter. With regard to the existence of these substances in the mineral world, the following reierences have been found:

$$
\text { Ladd, }{ }^{b} \text { quoting Le Chatelier, says: }
$$

It may be said to be well established that there are various hydrosilicates of aluminum which differ in proportion, form, and structure, some being colloidal amorphous, and some crystalline.

Comey ${ }^{c}$ speaks of halloysite as a colloidal clay.

Ries $^{d}$ found colloidal particles in some clays, and advanced the theory that plasticity was largely due to them.

Grimsley ${ }^{e}$ speaks of the colloidal theory as explaining the plasticity of clays, and notes that most clays contain from 1 to 5 per cent of grains which will take stain from methylene blue, gentian violet, eosin, or fuchsine. He found that the addition of 0.08 per cent of agar-agar increased the plasticity of clay very markedly, also that the addition of precipitated alumina if used without filtering or drying

$a$ Cushman, A. S., Effect of water on rock powders: Bull. Bur. Chemistry, U. S. Dept. Agr., No. 92, 1905 , p. 12.

$b$ Ladd, G. E., Preliminary report on a part of the clays of Georgia: Bull. Georgia Geol. Survey No. 6A, 1898, p. 15.

c Comey, A. M., Dictionary of Solubilities, 1896 , p. 361.

d Ries, H., Clays and clay industries of New Jersey: Final Repts. New Jersey Geol. Survey, vol. 6, 1904 , p. 83.

e Grimsley, G. P., Clays of West Virginia: West Virginia Geol. Survey, 1906, pp. 37, 46. 
had the same effect, but if air dried, no such increase was noted. $\mathrm{He}$ remarks that a colloid which will soften in water after drying is needed.

Wiley ${ }^{a}$ speaks of a colloidal constituent of the clay, designating by that term that portion of the clay which remains suspended almost indefinitely in pure water. He states that it is precipitated by brine, forming a gelatinous mass like the mixed hydrates of iron and alumina.

Cushman $b$ finds that "the action of water on many rock powders results in the formation of colloid films on the surface of the particles," and expresses the opinion that the binding power of rock dust, clays, and soils is due to the formation and presence of these films on the surface of crystalline or amorphous granules.

It will be noted from these extracts that the word colloid is very loosely' employed by various writers, many of them using it where hydrogel or pectoid would be more correct, while some seem to consider it as synonymous with amorphous.

Colloids, or more properly pectoids, possess the property of being readily stained by most organic coloring matters and of holding this color in an insoluble form. A familiar example is the use of alumina as a mordant in cotton printing, and Cushman ${ }^{c}$ states that orthoclase powder which has been wet ground to develop the pectoidal films takes up a brown stain from the Canada balsam used in mounting it for microscopic examination. On the other hand, it is well known that certain amorphous substances, not pectoids, also possess this property-for example, charcoal and boneblack. Grimsley ${ }^{d}$ states that "fresh gelatinized silicic acid will easily stain; air-dried silicic-acid jelly will take a stain with equal readiness." From his further remark that the addition of the air-dried jelly injures the plasticity of clay, I infer that this silicic acid had passed from the pectoid to the amorphous state. Samples of precipitated silica which I prepared acted in this way when dried in air or by washing with alcohol and ether.

Soils and clays have long been known to possess the property of absorbing certain materials, both gaseous and liquid. Wiley ${ }^{e}$ quotes many experimenters on this subject and from his work the following notes are taken. Clay exhibits a selective absorption of certain salts, holding the basic ions and rejecting the acidic ions. Way succeeded in producing an artificial hydrated silicate possessing absorptive powers. Eichhorn found that natural hydrated silicates or zeolites acted in a similar manner, and others have shown that the absorptive power bears a close relation to the amount of soluble silicates present.

$a$ Wiley, H. W., Agricultural Analysis. vol. 1, Soils, 1894. p. 231.

.$b$ Cushman, A. S., Effect of water on rock powders: Bulı. Bur. Chemistry, U. S. Dept. Agr., No. 92 1905, p. 12.

c Op. cit., p. 13.

$d$ G rimsley, G. P., Clays of West Virginia: West Virginiá Geol. Survey, 1906, p. 49,

$e$ Wiley, H. W., Agricultural Analysis, vol. 1, Soils, 1894, p. 118. 
Cushman $^{a}$ says:

Linder and Picton have shown that when a coagulated colloidal precipitate is formed in the presence of an electrolyte, a portion of the basic ions of the electrolyte is absorbed by or adsorbed on the pectoid matter in the form of hydroxide, while the acid ions remain free in solution. Many other investigators have checked this astonishing and interesting fact. * * * This absorptive power is in no sense of the word due to chemical combination, but-seems to depend upon the fine submicroscopic porosity of the pectoid.

It can be seen that as a result of this power of pectoids, it is in general impossible to wash a preparation of this character entirely free from the salts with which it is formed. Linebarger ${ }^{b}$ found it impossible to remove all the chlorine from colloidal ferric hydrate prepared from ferric chloride by dialysis.

Colloids and pectoids are destroyed by heat, in some cases probably by drying. Data on these-points seem to be sadly lacking, and there is also lacking a closely drawn distinction between pectoids and those bodies which are amorphous without being colloidal in their nature. However, as a certain amount of water is essential to the colloidal state, heating to a point at which the combined water is driven off must in all cases destroy this state. Further, it is probably true that a substance is colloidal as long as it retains its power of jellying with water either throughout or on the surface only. That some pectoids, at least, retain their characteristic properties after drying is shown by Cushman's experiments, but it is probable that the colloidal nature of alumina and silicic acid is largely destroyed by drying and is not capable of restoration by subsequent digestion with water. Whether an oil could take the place of water in promoting the colloidal state in mineral substances is an open question, but it is certain that organic colloids exist in oils, and it does not seem impossible that some mineral colloids may also.

Jones ${ }^{c}$ states that colloids diffuse very slowly as compared with crystalloids. As diffusion is due to osmotic pressure, this means that the osmotic pressure of substances in colloidal solution is very low. What bearing this interesting fact may have on the absorptive powers of colloids, I can not at present state, but it seems likely that they may be in some way connected.

\section{A NEW THEORY.}

The theory which I have devised to explain the peculiar properties of fuller's earth may be stated as follows:

1. Fuller's earth has for its base a series of hydrous aluminum silicates.

$a$ Cushman, A. S., Effect of water on rock powders: Bull. Bur. Chemistry, U. S. Dept. Agr., No. 92, 1905, p. 15 .

$b$ Linebarger, C. E., On the rate of diffusion of colloids: Jour. Am. Chem. Soc., vol. 20, 1898, p. 376.

$c$ Cushman, A. S., Effect of water on rock powders: Bull. Bur. Chemistry, U. S. Dept. Agr., No. 02, 1905, p. 251. 
2. These silicates differ in chemical composition.

3. They are, however, similar in that they all possess an amorphous colloidal structure.

4. The colloidal structure is of a rather persistent form and is not lost on drying at a temperature of $130^{\circ} \mathrm{C}$., or possibly higher:

5 . These colloidal silicates possess the power of absorbing and retaining organic coloring matter, thus bleaching oils and fats.

I have used the word colloidal in this statement in its broadest sense - to cover the whole range of conditions expressed by the words colloid, pectoid, and hydrogel. It is my opinion that the word pectoid would most properly express the condition of the active constituents of fuller's earth, but it is not impossible that these may go into partial solution in oil and thus become true colloids.

It will be seen by a study of the table of oil tests (p. 274) that the effect of acids on the bleaching efficiency of fuller's earth is. peculiar, some earths being much more affected than others. The Eimer \& Amend earth is evidently the least affected, and the Owl the most. I find it difficult to explain this except on the assumption that these earths contain several different minerals varying in amount and in ease of decomposition by acids, the bleaching power also being dependent on these minerals. I have noted on page 277 that the ease of decomposition by acids is for this series of minerals (the hydrous aluminum silicates) probably a function of the percentage of alumina and water, and we should expect to find this approximately true of the three earths tested in this investigation. An inspection of the ultimate analyses shows this to be so in a general way, and the parallel is much more apparent when we consider that the Owl earth contains about 15 per cent of lime carbonate as an impurity. The analyses of the residues after treatment with the acids and alkalies also show that the constituent silicates of the earth vary in resistance to acids. The improvement in efficiency of certain of the earths by treatment with dilute acids I attribute to the removal of limonite, calcite, and possibly some hydrous alumina, which may exert a clogging effect on the active minerals. This treatment may also increase the amount or the efficiency of the colloidal substance, as Cushman points out ${ }^{a}$ that certain salts and other substances possess the power of coagulating clay substance and increasing its binding power.

The wide variation in ultimate analysis which is exhibited in Table 3 (p. 272) and which persists even after recalculation eliminating impurities, is readily explained by this assumption of a series of similar. minerals. Variation in bleaching power of various earths is also thus explained, and if we can assume that these minerals have vary-

$a$ Cushman, A. S., Effect of water on rock powders. Bull. Bur. Chemistry, U. S. Dept. Agr., No. 92, 1905 , pp. 19, 22 . 
ing preferences for different classes of organic colors, we have a possible explanation of the puzzling fact that some earths which are very efficient for vegetable oils are useless on mineral oils, and vice versa. As bearing on the probability of this last assumption, Crampton and Simons ${ }^{a}$ find that fuller's earth absorbs much more color (caramel) from artificially colored spirits than from the natural, and remark that it appears to exert a selective action for some coloring matters.

In passing I wish to say that the possibility of the efficiency of fuller's earth being due to organic colloids has occurred to me, but after due consideration I decided that this theory was: untenable, as any organic matter was almost certainly destroyed in several of the acidtreated earths which gave fairly good results on oil.

As the recent work of Cushman and others has practically proved that the plasticity and binding power of clays and rock powders is dependent on the existence of pectoids, the nonexistence of plasticity in fuller's earth would certainly be a stumbling block to my theory. However, as I have shown on page 273 , the earths on which I have worked possess a most decided plasticity, and an investigation is needed to determine the correctness of the numerous statements to the contrary. The property which I noted, of taking up very large quantities of water before reaching the plastic state, is certainly an attribute of colloids, and the extreme greasy or soapiness of feel is not less so.

The action of high temperature in destroying the efficiency of fuller's earth (see oil test No. 6, Table 5, p. 274), although it does not of itself prove the presence of colloids, at least agrees well with that theory, as it is well known that the colloidal structure is destroyed by heat, whereas an amorphous structure is unaffected.

Fuller's earth in suspension in water, in common with other clays, is readily coagulated and settled by traces of acid or larger quantities of salts. Wiley ${ }^{b}$ calls this fine suspended matter colloidal clay, and it probably does consist of kaolin particles which are more or less pectinized on the surface. I have noticed in washing fuller's earth after it has been treated with sodium hydrate that it settles readily during the first decantations; then, as the amount of sodium hydrate becomes less, a part refuses to settle, and that which does settle becomes more gelatinous and swells until it occupies a volume several times as large as the original. On adding a few drops of acid to neutralize the sodium hydrate the earth settles readily. On drying, however, the earth forms a hard, hornlike mass similar to precipitated alumina. I explain these facts as follows: It is well known that alka-

a Crampton, C. A., and SImons, F. D., Detection of caramel in spirits and vinegar: Joụr. Am. Chem, Soc., vol. 21, 1899, p. 356 .

b Wiley, H. W., Agriculțural Analysis, vol. 1, Soils, p. 231. 
lies prevent flocculation of colloids and that acids and neutral salts promote it. This explains the nonsettlement of the earth. As for the gelatinization, it is evident that the strong alkali has the power of partially decomposing the earth and of converting the compact, resistant pectoids into a softer form that requires more water and is perhaps between a pectoid and a soluble colloid and similar to precipitated alumina.

Colloids are known to possess the power of taking up organic colors from solution (see p. 282), and the analogy with fuller's earth is so apparent as to excite surprise that it has not been studied from this point of view before. It has even been known that pectoids could extract colors from oils and resins as well as aqueous solutions. This I regard as a strong point in favor of the colloidal theory, although by itself it does not, of course, constitute a proof.

The power of colloids to absorb certain salts, or at least the basic ions of these salts, has been known a long time. It is also possessed to a degree by certain amorphous substances having a fine porous structure, such as charcoal and boneblack. Fuller's earth has this property to a marked degree. In fact, its use has been proposed to remove the lime from boiler water. ${ }^{a}$ I have found that after it has absorbed ammonia or salts it loses a great part of its efficiency in bleaching oils. From this I infer that the bases are absorbed in a similar manner to the coloring matter of oil, and occupy the pores which otherwise would hold the color.

It has been pointed out that these absorbent materials have a selective action on the salts, absorbing the unlike ions and discarding the ions of like chemical nature. If colors in oil solution are absorbed in the same manner as salts in aqueous solution, analogy would lead to the supposition that fuller's earth would exert a selective action for certain classes of coloring matter and, moreover, that the earths themselves would differ in their selection of colors according as they are more or less acidic in composition. We find this entirely in accordance with the facts.

I have noticed in the course of my oil tests that on the same sample of oil different materials give products varying greatly in shade, the main color being in some tests of a yellow and in others of a green tint. Is it not likely that the oil contains several compounds of varying chemical nature, and that the earths or other materials used in bleaching extract them in ratios proportional to their own basicity or acidity? I have been unable to obtain any exact data on this point from my results, owing to the difficulty of following these slight changes in tint with the unaided eye. A tintometer would be needed if this line of investigation were to be followed out. 
I believe that the reason for using heat in bleaching oils is that the lessened viscosity of the oil when heated allows the molecules of color to come into better contact with the particles of earth. Possibly, however, the beneficial result is partially due to the expulsion of water or air from the submicroscopic pores of the pectoid surface, thus making room for the coloring substance.

The table of oil tests (p. 275) shows that pipe clay, which is nearly pure kaolin, has. some slight bleaching power. This is in line with the colloidal theory, taken in connection with Cushman's experiments on kaolin, in which he found that the kaolin grains were coated with a thin layer of pectoidal substance. This coating should be sufficient to give the kaolin the slight bleaching power it was found to have.

Tests Nos. 31 and 32 show that the kaolin is improved in bleaching efficiency by drying and also by decomposition with sulphuric acid. According to the colloidal theory, the improvement on drying is possibly due to the expulsion of the excess of water from the thin pectoid film on the surface of the crystals. The treatment by sulphuric acid, however, entirely decomposes the kaolin and leaves an amorphous . silica, the excess of water being removed by the dehydrating action of the acid. It will be noted that the silica from the pipe clay does not vary much in efficiency from those samples prepared from fuller's earth in the same manner, especially when the latter have been thoroughly decomposed. It is also of interest to note that the silica from kaolin giving a color value of 16 does not differ very much from that prepared by precipitation and washing with alcohol and ether, value 18 .

The limestone clay, which I found had a very considerable bleaching power, was probably in a more pectoidal state than the kaolin, and it is evidently to be expected that all gradations of bleaching power will be found in the various clays.

This same idea will apply to the fine mineral powders which Wheeler discovered to have a slight bleaching action. I do not know whether or not his powders were wet ground. If so, pectoidal substances were certainly contained in them. If ground dry, their efficiency is probably due to the increased surface action of amorphous particles.

At this point it seems necessary to examine into the difference, if any, in the mode of action of colloids and amorphous substances. It has been pretty well proved that the decolorizing power of charcoal and bone char (amorphous substances) is due to their exceedingly small "submicroscopic pores." These pores seem to be exceptionally well developed by certain forms of carbonaceous matter, but probably exist to a greater or less extent in all forms of finely divided amorphous matter. This, I take it, explains the small but uniform efficiency of such materials as precipitated and dried silica and alumina, and, as before noted, may also explain the results which Wheeler obtained with very finely pulverized materials. It is evident that the 
slightest trace of sintering on material of this sort would close up these minute pores, and no doubt this is the cause of the destruction of the decolorizing power by ignition. (See tests Nos. 47 and 51, Table 5, p. 275.)

The mode of action of colloidal substances is probably very similar, even though the body of material containing the poresis of so different a nature. As before noted, many investigators have found that pectoidal substances possess the power of absorbing the basic ions of salts into their "fine submicroscopic pores," and there is no reason to think that the ions of coloring matter are held in any different way.

However, I must confess that I do not feel very clear in my mind as to the exact state or characteristics of what I have called the efficient pectoids. So little that is really definite is known on the subject that it is very difficult to draw a hard and fast line between colloids and amorphous bodies. Possibly all intermediate states between the soluble colloid and the most insoluble amorphous substance exist. If this is the case, it will lead to many interesting speculations. For example, it is possible that the more nearly a substance approaches the purely colloidal state the greater affinity it will have for coloring matter; but in the case of oil bleaching this state will be limited by the necessity of increased water in the softer colloids. At some intermediate point the maximum efficiency for oils would be found. The difficulty of preparing alumina without including a large excess of water is evidently the cause of my failures with that substance. We know that alumina has a strong affinity for coloring matter in aqueous solutions and very probably it would act with equal efficiency on oil, if it could be prepared without the water. It seems likely that the drying to a horny mass is an attribute of the softer and more highly hydrated colloids. Silicic-acid jelly when dried forms such a mass, but if it is first washed with alcohol and ether (which removes the excess of water) it dries to a white pulverulent powder, still, however, containing much combined water. - It will be noted (see test No. 50) that when so prepared it has a slight efficiency. Fuller's earth also when treated with sodium hydrate swells, softens, and apparently takes up much water, forming a softer colloid. - On drying it acquires the hornlike characteristics of dried alumina and loses considerable efficiency. (See also p. 286.) Another possible explanation of the action of dilute acids in increasing the efficiency of some earths occurs to me here. May not the acids decompose and remove the very soft and hydrous colloids and thus prevent their drying up and clogging the efficient particles? Another query in the same line: Might not strong drying decrease the efficiency of some earths that contain a larger proportion of the softer colloids, and would not a considerable variation in resistance to heat be found if many earths were tested? There is evidently room for much research along these lines. 
I come now to a very interesting phase of my subject, although I have not studied it to any extent-namely, the bleaching action of light on oils. A study of the tables reveals an exceedingly significant fact. The after bleaching (or bleaching due to the action of light) appears to be much greater in the more efficiently bleached samples than in those which were only slightly bleached. I say "appears to be," because my color scale, although comparatively correct, is not absolutely so. In other words, the absolute percentage of coloring matter in the samples will not vary in the same amount from number to number. However, even if we allow for this, it seems almost certain that this after bleaching can not be altogether due to the chemical action of the light on the coloring substance, for in that case all samples should bleach a uniform amount. It seems necessary, therefore, to look elsewhere for the cause of this action, and as yet I have been unable to devise a satisfactory hypothesis.

It is evident that the colloidal theory is most susceptible of proof by means of microscopic work, but for lack of an instrument of sufficiently high power I have been able to do but little in this direction. Such results as were obtained, however, tend to confirm this theory.

Fuller's earth, dry (Fairbank No. 2), appears to be made up of a mass of small amorphous mossy particles that look something like lumps of half-dried alumina and seem to contain many tiny air bubbles. By transmitted light many small plates are seen. Some grains that are not plates are also visible, and a very few grains of a color varying from deep red to reddish yellow. Some particles have the look of small rings or groups of rings. I believe this to be due to the presence of transparent crystalline plates which have commenced to alter to an opaque substance around the edge. Fuller's earth treated with sulphuric acid also shows these rings. Kaolin shows extremely fine particles that are not mossy looking, and although these particles are so fine that their form can not be distinguished, yet their sharpness of outline and noncoherence point toward the crystalline structure.

Limestone clay shows large quartz grains, mossy lumps, like ferric hydrate, and large grains that are transparent in places, but are apparently covered with a brown mossy substance, like ferric hydrate.

Most of the other materials tested were also examined under the microscope, but nothing of any great significance was noted.

PRACTICAL APPLICATION OF COLLOIDAL THEORY.

If, as I anticipate, further investigation establishes the fact that there is a well-defined relationship between the rational composition of fuller's earth and the class of coloring matters which it removes most efficiently (see pp. 268, 284), there will evidently be afforded to chemists a means of predicting the value of fuller's earth and the class of work for which it is best adapted, on the basis of analysis. A little 
study is needed to determine simple methods of rational analysis, but to judge from my experiments with acid treatment it is not likely to be a difficult problem.

These experiments also suggest the possibility. of considerably increasing the bleaching efficiency of fuller's earth by treatment with dilute acids or similar means. There is no doubt that this can be done, but further investigations are needed to find more favorable conditions and to show whether the process can be made sufficiently economical for commercial use. It is also probable, as I have already pointed out (p. 287), that fuller's earth may vary in resistance to heat and in the degree of dryness needed. A close study of this phase of the subject might show how the preparation of the earth affects its bleaching qualities and point the way to an increased efficiency.

Finally, we come to the possibility of creating an artificial bleaching agent capable of doing the work of fuller's earth. I have no doubt whatever that many common clays can be found which possess a certain amount of bleaching power and which by proper treatment can be given an efficiency equal to fuller's earth. I am more skeptical as to the practicability of treating a neutral or nearly neutral body so as to make it an efficient bleaching agent. It is possible that future work may discover some artificial pectoidal body which will possess the same resistance to drying as the active pectoids of fuller's earth. In that case I can see no reason why it should not be possible to impregnate a kaolin or other porous medium with this substance and make of it an artificial earth. I am of the opinion that some such substance may be found among the organic colloids, although the single test I made along this line (test No. 41) was barren of result.

\section{RATIONAI, COMPOSITION OF FULLER'S EARTH.}

Table 6 gives the approximate rational composition of the fuller's earths on which I have worked, as calculated from the analyses given in Table 3 (p. 272). The calculations are based on the percentages of silica, alumina, and water soluble and insoluble in the different strengths of acids, and I believe they come somewhere near the truth. It will be noticed that the figures do not exactly balance with the ultimate analyses, but they are probably as close as could be expected. 
TABLE 6.-Rational analyses of fuller's earth.

\begin{tabular}{|c|c|c|c|c|c|c|c|c|c|}
\hline Mineral. & Total. & $\mathrm{SiO}_{2}$ & $\mathrm{Al}_{2} \mathrm{O}_{3}$ & $\mathrm{Fe}_{2} \mathrm{O}_{3}$ & $\mathrm{CaO}$ & MgO & $\mathrm{CO}_{2}$ & $\mathrm{H}_{2} \mathrm{O}$ & $\mathrm{P}_{2} \mathrm{O}_{5}$ \\
\hline owL. & & & & & & & & & \\
\hline Apatite:. & 2.62 & & & & 1.42 & & & & 1.20 \\
\hline Calcite.. & 16.82 & & & & 9.42 & & 7.40 & & \\
\hline Magnesite.. & 1.01 & & & & & 0.48 & .53 & & \\
\hline Montmorillonite.. & 32.04 & $17.21^{\circ}$ & 9.70 & & $\ldots$ & & & 5.13 & \\
\hline Free hydrous silica. & 5.46 & 5.00 & & & & & & .46 & \\
\hline Iron oxides.. & .82 & & & 0.82 & & & & & \\
\hline Magnesia (?). & 1.24 & & & & & 1.24 & & & \\
\hline Anauxite.............. & 24. 41 & 14.84 & 6.25 & & & & & 3.32 & \\
\hline \multirow{3}{*}{ Feldspar and quartz........................ } & 5.90 & 1.93 & 1.41 & 1.15 & & 1.41 & & & . \\
\hline & 9.73 & 9.22 & .44 & .12 & & & & & \\
\hline & 100.00 & 48. 20 & 17.80 & 2.09 & 10.84 & 3.13 & 7.93 & 8.91 & 1.20 \\
\hline \multicolumn{10}{|l|}{ FAIRBANK. } \\
\hline Apatite... & .14 & & & & .08 & & & & .06 \\
\hline Free hydrous silica. & 11.97 & 11.90 & & & & & & .07 & \\
\hline Prehnite (?)...... & 10. 16 & 4.43 & 2.54 & & 2.75 & & & .44 & \\
\hline Other zeolites. & 2.07 &. .57 & & & .11 & 1.39 & & & \\
\hline Iron oxides... & 2.12 & & & 2.12 & & & & & \\
\hline Anauxite... & 45.88 & 27.90 & 11.74 & & & & & 6.24 & \\
\hline Augite, etc.. & 19.76 & 9.61 & 3.30 & 4.91 & 43 & 1.51 & & & \\
\hline \multirow[t]{2}{*}{ Quartz and feidspar..................... } & 7.43 & 5. 00 & 2.32 & .11 & & $\mid \begin{array}{ll}1.01 \\
\cdots \cdots . .\end{array}$ & & $\cdots \cdots$ & $\begin{array}{ll}\cdots \\
\cdots \cdots\end{array}$ \\
\hline & 99.53 & 59.41 & 19.90 & 7.14 & 3. 29 & 2.90 & .04 & 6.95 & .06 \\
\hline EIMER \& AMEND. & & & & & & & & & \\
\hline \multirow{7}{*}{ 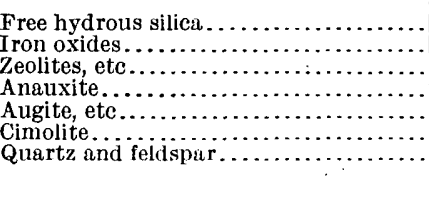 } & 10.88 & 10.38 & & & & & & .50 & \\
\hline & $\begin{array}{l}3.80 \\
7.2 ?\end{array}$ & 200 & 134 & 3.80 & $\because 3$ & 67 & & $\cdots_{i i}$ & \\
\hline & 29.44 & 20.25 & $\begin{array}{l}1.49 \\
6.00\end{array}$ & & 2.80 & .08 & & 3.19 & \\
\hline & 14.55 & 4. 56 & 4.52 & 4.00 & & 1.47 & & & \\
\hline & 27.78 & 17.64 & 6.64 & & & & & 3.50 & \\
\hline & 8.27 & 5.37 & 2. 40 & & & .50 & & & \\
\hline & 101.86 & 60.20 & 21.00 & 7.80 & 2.80 & 2.64 & n. d. & 7.50 & n. d. \\
\hline
\end{tabular}




\section{CLAYS OF THE BIRMINGHAM DISTRICT, ALABAMA.}

By Charles Butts.

\section{INTRODUCTION.}

The area here designated the Birmingham district covers about 1,000 square miles lying, in the main, north of Birmingham, Ala. In it are located a number of brickworks, utilizing local deposits of clay and shale. This paper is based on work done in the field by Chester W. Washburne, William F. Prouty, E. M. Dawson, jr., and the writer. Information drawn from published reports has been acknowledged in the proper place.

\section{- CLAY.}

The clay is sedimentary and occurs either as a surficial deposit or as the underclay of coal seams. So far as known the only important superficial deposit of clay in this area occurs along Turkey and Cunningham creeks, south and east of Morris.. This clay has been worked to a considerable extent for brickmaking at De Soto, on the Moss property, but the plant has not been in successful operation in recent years. The clay here is reported to be 10 to 12 feet thick, and shows the following section:

Section at Moss brickworks, De Soto.

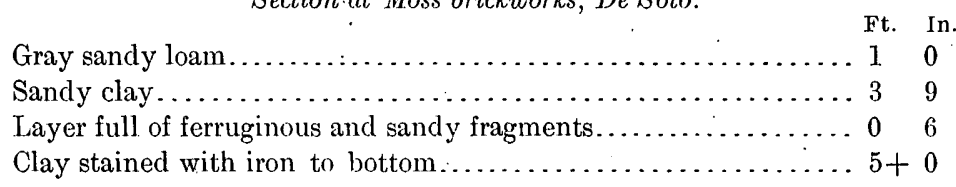

The entire thickness of the deposit is used. The bricks made from this clay are of a good, red color and are said to be of excellent quality, but to shrink a good deal in drying.

The clay in this locality is reported to occur in irregular patches of unknown shape and extent as far down Turkey Creek as the bridge south of Morris. Clay was noted along the Louisville and Nashville Railroad, half a mile east of Morris, and at a point midway between Fedora and Indio. It seems not unlikely that the clay deposit is coextensive with the flat ground along Turkey Creek, from Fedora to Indio, and along Cunningham Creek, for $2 \frac{1}{2}$ miles above its junction 
with Turkey Creek, though it probably varies much in thickness and quality in this area.

This deposit of clay accumulated during the time that the creek waters were more or less ponded from some cause, for the clay is evidently composed of fine material that was washed down from the surrounding hills and slowly settled in still water. The cause of the ponding may have been a stratum of sandstone which crosses Turkey Creek nèar the bridge south of Morris and which retarded the downcutting of the creek bed and acted as a dam to the water above.

The only underclay utilized in the Birmingham quadrangle is that under the Black Creek coal seam at Coaldale and vicinity. It is a gray plastic clay and makes a buff brick. It has been mined near the Southern Clay Company's brick works at Coaldale and at the Butterfly mine, about 1 mile east of Coaldale. At both points it is 4 feet thick. Its further extension is unknown to the writer, but there is evidently a considerable body of good clay in this locality. From both the places just mentioned the clay has been shipped to Birmingham and Bessemer for fire brick and terra cotta. It is now being mined at the Butterfly mine by the Sibley-Menge Press Brick Company for use in its new works 1 mile north of Coaldale. It is used for dry-press face brick of buff color, is mixed with shale for gray brick, and, with the addition of manganese, is used for speckled brick.

A bed of clay 4 to 6 feet thick underlies the Nickel Plate or American coal seam at Baileys Quarters, northeast of Brookside, where it is exposed in a cut of the North Alabama Railroad: The same clay also shows in a cut of this railroad at Clift station. Here there are three beds, two of which are each 2 feet thick and one 18 inches thick. A bed of clay 3 to 4 feet thick occurs at the same horizon at Short Creek, and clay of greater or less thickness has been noted under the same coal at other points in the region. It has not been utilized and nothing is known of its qualities.

A bed of very white, soft, plastic clay, $2 \frac{1}{2}$ feet thick, underlies the Pratt seam at the Thompson mine, northwest of Sayreton, but gen-

- erally the coal seams of this region appear to be without.underclays of economic importance.

\section{SHALE.}

The Alabama coal measures, reaching, in the deepest part of the Cahaba trough, nearly 7,000 feet in thickness, are made up of alternating shale and sandstone, the shale forming about two-thirds of the whole. Most of the shale is probably suitable for brick making. Shale from three different horizons in the Warrior basin and from one horizon in the Cahaba trough is now being utilized for brick. A project is afoot to use a lower Carboniferous shale for the same purpose also. 
The highest bed of shale used for brick is that above the Mary Lee coal group in the Warrior basin. This is generally a blue clay shale, weathering yellow, about 200 feet thick. It is a persistent stratum, extending throughout the Warrior basin in this area where not removed by erosion. It is very uniform in appearance, though, as stated below, considerable variation in composition may occur at different points or at different levels. The vertical continuity of the shale is broken here and there by a layer of sandstone up to 10 feet thick or possibly more at some points.

Shale from the bottom of this mass is extensively used for brick by the Graves Shale Paving Brick Company, at Graves.

Below is a section of the shale quarry at this place:

Section of shale beds at Graves.

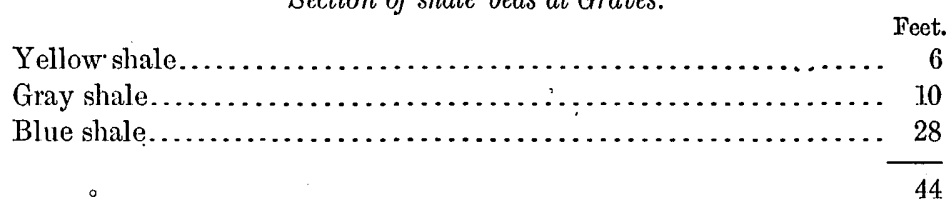

The shale dips from $10^{\circ}$ to $15^{\circ} \mathrm{W}$., into the hill. According to Ries, ${ }^{a}$ the yellow shale is somewhat sandy and has a large content of ferric oxide. It vitrifies at $2,250^{\circ} \mathrm{F}$. and fuses at $2,500^{\circ}$, yielding a brick that has a tensile strength of 4.0 pounds per square inch. The gray shale is less sandy and ferruginous. It vitrifies at $2,200^{\circ} \mathrm{F}$. and fuses at $2,500^{\circ}$, yielding a brick of good red color, with an average tensile strength of 105 pounds per square inch. The brick are burned for nine days in round down-draft kilns. Paving brick and chemical brick are made. The latter are used principally for packing acid chambers in making sulphuric acid, a use for which they are well adapted, since, on account of their density, they absorb almost no water. The daily capacity is 50,000 brick and the actual output is reported to be 28,000 to 38,000 daily.

At Coaldale shale from two horizons is used. The upper horizon is that of the Jefferson coal seam and the lower is on an average about 150 feet below the Black Creek coal seam.

Shale from the upper horizon is utilized by the Southern Clay Manufacturing Company for vitrified paving brick.

The section at this company's quarry is as follows:

Section at Southern Clay Manufacturing Company's quarry, Coaldale.

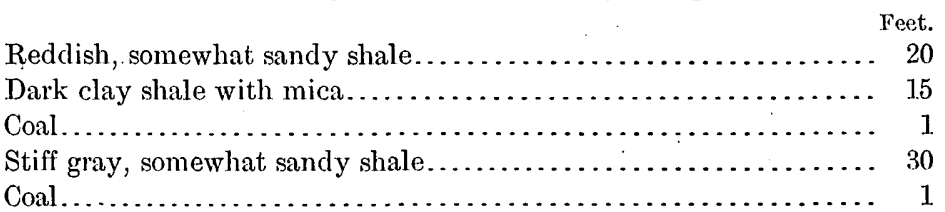

a Ries, Heinrich, Bull. Alabama Geol. Survey No. 6, 1900, p. 185. 
The shale dips at a low degree to the east and, as it outcrops near the top of a hill, conditions for quarrying are very favorable. The 20 feet of reddish shale may differ from the underlying 15 feet of dark shale only in being more weathered. While the lower 30 feet of gray shale has been used, only that from the upper 35 feet is used at present in the proportion of two parts of red shale to one of dark. A test, apparently of the red shale, showed that vitrification takes place at $2,000^{\circ} \mathrm{F}$. and viscosity at $2,150^{\circ} \mathrm{F}$. The brick are burned in round down-draft kilns for nine days. They are red or brown. The capacity of this plant is 30,000 daily.

The shale lying 100 to 200 feet below the Black Creek seam is used for dry-press brick by the Sibley-Menge Press Brick Company, whose plant is about 1 mile north of Coaldale. The shale lies nearly flat and the bed is at least 70 feet thick, but only shale from the bottom 20 feet is used at present. In its weathered condition this is a gray clay shale, apparently with very little mica and sand. It makes a fine drypress face brick of a pleasing red color. As stated on page 292, it is mixed with the underclay of the Black Creek coal seam for gray brick. The capacity of the plant is about 60,000 brick daily. No analyses of the shale nor physical tests of the brick have been made, so far as known to the writer, nor does he know whether the upper part of the shale bed is equally good for brick.

At Lovick, in the Cahaba coal field, shale lying between the Gould and Nunnally coal groups is being extensively worked at the brick plant of L. L. Stevenson. The whole bed utilized has the following section:

Section at Stevenson brick works, Lovick.

Feet.

Reddish shale, probably weathered phase of gray shale below........ 10

Gray clay shale................................... 18

Blue-black carbonaceous clay shale, with fossils............... 20

Shale from all these layers is mixed and used for pale-red common brick or brown vitrified brick. The time of firing is nine days, three days at low heat to expel the water and six days at red heat and finally at white heat. The capacity of the plant is 80,000 brick daily and the actual output is large. No analyses nor physical tests have been made.

The Lovick shale is traceable by its characteristic dark fossiliferous shale band for 6 miles southwest of Lovick. It is particularly well shown along the Leeds-Birmingham road in the southwest corner of sec. 28 , T. 17 S., R. 1 W. It extends northeastward along the west side of Owens Mountain to Parsons station and beyond. At Lovick this shale dips $8^{\circ} \mathrm{E}$., but both to the north and the south the dip reaches $20^{\circ}$. 
A project is on foot to start brick works near Leeds, on the Southern Railway, using lower Carboniferous shale from the SW. $\frac{1}{4} \mathrm{SW} . \frac{1}{4}$ sec. 14, T. 17 S., R. 1 E. The composition of this shale, as shown by analysis, is such as to make it suitable for brick.

Not only at the points described above are the shales well adapted to briek making, but also at many other points on the same or other horizons throughout the area. It appears, therefore, that there are unlimited quantities of shale in this district from which high-grade paving and building brick can be made. At many points the conditions as regards quarrying the shale, cheap fuel supply, and transportation facilities are favorable for the location of brick works. The shale brick made in this region find an active market throughout the Southern States. 


\title{
CLAY DEPOSITS OF THE WESTERN PART OF THE DURANGO-GALLUP COAL FIELD OF COLO- RADO AND NEW MEXICO.
}

\author{
By Miluard K. Shater and James H. Gardner.
}

\section{INTRODUCTION.}

The greater part of the area here considered lies in northwestern New Mexico, but a portion is included in southwestern Colorado. ${ }^{a}$ In connection with reconnaissance work done in 1906 in this coal field, brief notes were taken regarding the occurrence and development of clay and shale deposits. As the region is but sparsely settled and at present lacks adequate railway facilities, the clay industry supplies only local demands and a small outside market. The total value of clay products marketed from this field in 1905 was about $\$ 75,000$. The demand for clay and shale to be used in the manufacture of building material, tiles, conduits, etc., will naturally increase as the region develops and as better railway facilities become available. The occurrence of good coal in quantity in this region will do much to aid the development of a considerable clay industry.

At some places in the field limestones with which to mix the clay or shale in the manufacture of Portland cement occur near at hand, and some of them are of the proper composition for this use. The fire clays of the area so far tested contain a rather high percentage of fusible material, particularly iron oxide, but their adaptability for use in making semirefractory products and for lining copper converters has been shown at Durango and in copper smelters in Arizona.

\section{CHARACTER OF THE CLAYS.}

The clays of the area may conveniently be classified as clay shales, plastic clays, and fire clays.

The clay shales include in greater part the thick shale formations of the area - the Mancos and the Lewis-as well as many thinner beds intercalated with the sandstones and coal beds of the Mesaverde ${ }^{b}$ and Laramie formations. All of these formations are of Upper Cretaceous age.

a For a more detailed location see report on the coal of this region by $M$. $K$. Shaler in a forthcoming bulletin of the Survey.

$b$ For definition of the Mesaverde formation see description of the La Plata quadrangle, folio 60, U. S. Geol. Survey, p. 5, 1899. 
The plastic clays include alluvial beds, adobe clays, certain unconsoliclated Tertiary shales, and residual deposits derived from the weathering of clay shales.

The fire clays include deposits of a semirefractory nature, the beds of which now mined are interbedded with the sandstones, shales, and coals of the Mesaverde formation. Some of these are directly associated with the coal beds and are mined in connection with them.

\section{COMMERCIAL DEVELOPMENT.}

Durango-Mancos district.-The present development of the clay industry in the Durango-Mancos district; so far as known, is confined to the vicinity of Durango, Colo. The Durango Pressed Brick Company began operations as early as 1898, and in 1902 two plants were manufacturing bricks near Durango, but the company named is the only one now operating in the district. The plant is located on the Rio Grande Southern Railway 1 mile west of Durango. The shale used in making building brick is procured from the upper part of the Mancos, about 100 feet stratigraphically below the lowest coal bed of the Mesaverde formation. It is dark gray or black in color, hard, and at some places contains a little lime as a physical impurity. This lime is, however, generally present in concretionary form, and can be easily removed while the shale is being quarried. It is reported that nearby beds contain. a higher percentage of lime than the bed quarried at this brick plant. The following analysis of the shale was made by P. H. Bates at the structural material laboratory of the United States Geological Survey at St. Louis.

Analysis of shale from quarry of Durango Pressed Brick Company.

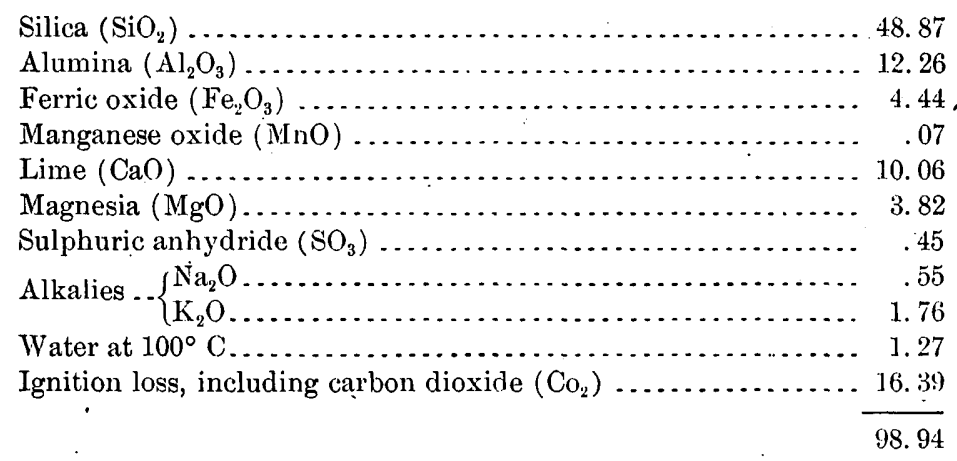

The color of the burned bricks is red. A dry-press Boyd machine is used in their manufacture. It is reported that the bricks shrink very little after sun drying.

The Durango Pressed Brick Company produces each year a small output of a semirefractory brick, which is generally used for boiler linings. In the manufacture of this class of brick the clay from a bed 2 to 5 feet in thickness, lying just below the coal bed above mentioned, 
is mixed in proper proportion with the Mancos shale of the quarry. The color of this clay is dark blue. It is hard and is quite free from physical impurities. The bricks produced are white to buff in color.

Between the longitudes of Durango and Mancos the Mancos shale and some of the fire-clay beds in the coal-bearing Mesaverde formation occur in continuous outcrop. The Mancos also forms the basal part of Mesa Verde, a wide mesa lying just south of Mancos. Another shale bed, the Lewis, having a total thickness of about 1,600 feet and differing little in character from the Mancos, outcrops between the Mesaverde and Laramie formations in Rages Basin, southwest of Durango. Its exposure is continuous westward as far as La Plata River in the vicinity of Fort Lewis. Nowhere in this district, so far as known, has any part of this shale been worked for the manufacture of clay products; hence a practical test of its adaptability to such purposes is as yet entirely lacking. Judging from its physical characteristics, however, this shale bed doubtless is, in part at least, well adapted to the manufacture of ordinary brick.

With the exception of the San Juan and Gallup districts, yet to be discussed, this district is the only one in the field having at present the transportation facilities and markets necessary for any great development of the clay industry, and even this district is greatly handicapped by high freight rates and a consequent limited market. The market for the clay products of Durango outside of the local demand extends to Chama, N. Mex., on the east, and to Telluride and Silverton, Colo., on the north.

Vitrified brick has had, as yet, no market in this district; hence no attempt häs been made to utilize the shales for the production of brick of this class.

At Rockwood, on the Denver and Rio Grande Railroad, about 16 miles north of Durango, limestone is quarried with which the shale of the Durango Pressed Brick Company's quarry might be mixed in the manufacture of Portland cement. An analysis of this limestone, made by P. H. Bates, at the structural material laboratory of the United States Geological Survey, follows:

Analysis of limestone from the Rockwood quarry.

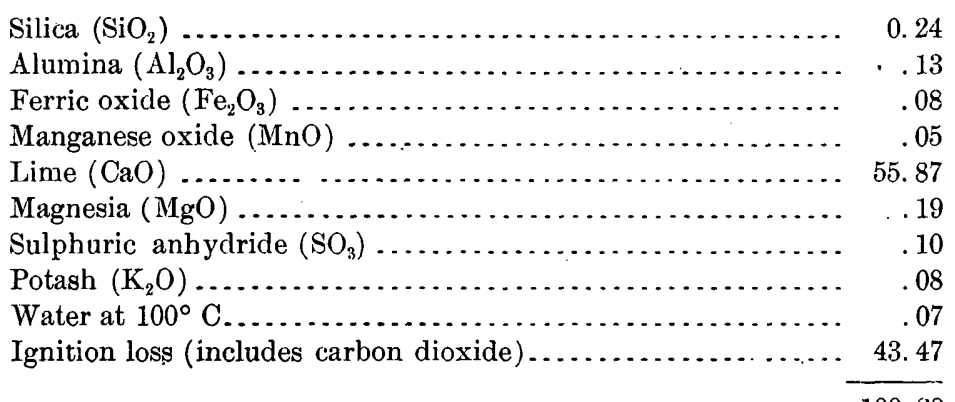


San Juan district.-The clay industry of the San Juan district is limited to Animas and San Juan valleys, New Mexico. In Animas Valley, at Farmington, a small brick plant has been in operation since 1900, and at Flora Vista and Aztec bricks have been manufactured since 1903. The production of this valley finds an outlet to Colorado markets over the branch line of the Denver and Rio Grande Railroad, which has recently been constructed down the valley from Durango. In 1903 a plant at Farmington successfully began the manufacture of what is known as "granite blocks," a building material manufactured largely from clay.

In San Juan Valley a production of building brick was reported from Fruitland by Biggs \& Stephens in 1901. At Jewett and Shiprock building brick to supply a local demand were produced in 1903. At Shiprock the Government Indian School and Agency buildings were constructed during 1904 and 1905 of brick made on the ground from Mancos shale.

In both Animas and San Juan valleys, excepting in cases already noted, residual clays are used in the manufacture of brick. The product is common red building brick, and the market is local.

Gallup district.-The Gallup district centers about Gallup, N. Mex. The clay industry at Gallup and Clarkville, a coal-mining camp about 4 miles west of Gallup, consists almost wholly of the production of semirefractory fire clay, which is shipped to the copper smelters of southern Arizona, there to be used for the purpose of lining copper converters. Two companies at Gallup and one at Clarkville are now producing this semirefractory fire clay. At the Clark mine at Clarkville and at one place at Gallup the clay is worked in connection with coal mining. In the Rocky Cliff mine at Gallup the clay bed is from 10 to 20 feet thick and lies between two coal beds. After the lower coal bed is taken out the timbers are removed and the fire clay is allowed to fall; then the upper coal bed is mined. Two or three cars of this clay are shipped every day from this mine to southern Arizona.

Just south of the town limits of Gallup fire clay has been mined for five years by the Rocky Cliff Coal Mining Company. The bed varies in thickness from 7 to 11 feet. No timbering is necessary, as the bed is immediately overlain by a bed of massive sandstone. Until recently the production of this mine was rather large, two or three cars being shipped daily for use in Arizona smelters.

At Clarkville there are several beds of this semirefractory clay, varying in thickness from 1 to 20 feet. The beds lie comparatively flat and are of wide areal extent. About 12,000 tons of clay are produced annually at the Clark mine, and this production has been continuous since 1898. The clay is all shipped to the United Verde Copper Company, at Jerome, Ariz., where it is used for lining copper 
converters in the smelting process, a use to which it is well adapted. An analysis of this clay is as follows:

Analysis of clay from the Clark mine, Clarkvilie, N. Mex.

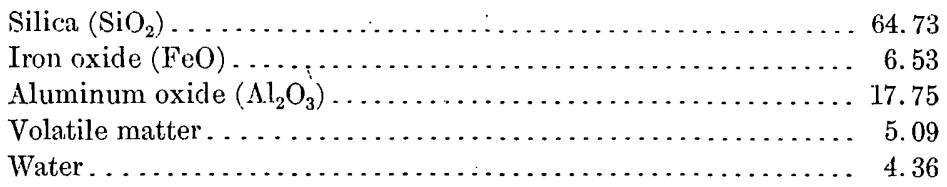

It will be noticed that the content of fusible material, principally iron oxide, is rather high for a fire clay, but the presence of this impurity does not seem to be detrimental to its use as converterlining material. Many of the copper ores themselves contain a high percentage of iron, hence that present in the converter lining, if in rather small quantity, does not add greatly to the total percentage. It must be borne in mind, too, that the linings of copper converters are renewed before nearly every charge of ore, so that a lining of absolute refractory character is unnecessary. Quartzite is sometimes mixed with the clays used for this purpose, with the effect of greatly reducing the relative percentage of iron in the lining.

Besides this production, which in itself amounts to nearly 30,000 tons annually, valued on the cars at the quarries and mines at about $\$ 1.15$ per ton, some building brick have been successfully made from the Mancos shale that outcrops in the "Hogback" 2 miles east of Gallup. The production of these brick has been limited by the local demand, and none have been produced for several years. As is shown by the following analysis made by Prof. Erasmus Haworth, of Kansas State University, this shale is not an exceptionally good brick shale, being rather high in lime. The presence of this, however, would not be detrimental if the shale were comparatively free from carbonaceous matter, but unfortunately its carbonaceous content is rather large, the ignition loss, probably in great part organic matter, being somewhat high.

Analysis of Mancos shale from Hogback east of Gallup.

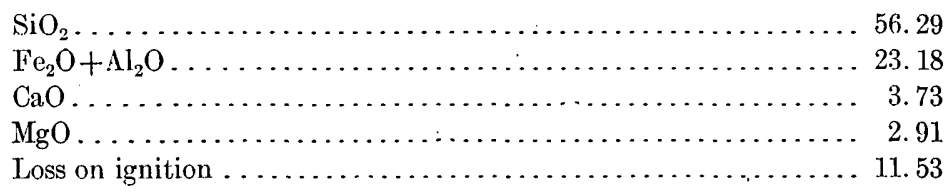

It is possible that this shale bed or other beds in the overlying Mesaverde formation might be utilized, with some of the limestones occurring southeast and east of Gallup, in the manufacture of Portland cement. No analyses of these limestones have yet been made, however, so that a definite statement as to their quality is at present impossible. 
The Carboniferous (Aubrey) limestone, which occurs near the railroad some distance east of Gallup, and alșo in the vicinity of Fort Wingate and Nutria southeast of Gallup, appears to be a limestone of very pure grade and might be used in connection with this shale in Portland cement manufacture. The abundance of coal at Gallup and in its vicinity, and the fact that no Portland cement plants are located near enough to this point to compete seriously with a plant established here are factors that might insure the success of such a plant. ${ }^{a}$

Other areas in the field.- The only areas within the field that could possibly, under present conditions of transportation, produce clay of any kind on a commercial basis have been discussed above. This limitation, however, is entirely dependent on present transportation facilities and market conditions and not on the absence of good clay and shale deposits.

South of Jewett the Mancos shale outcrops over a wide area west of the "Hogback" to the latitude of Crozier, where it disappears, dipping steeply eastward under flat-lying Tertiary sediments and lavas. At the southern limit of the Choiskai Mountains, east of Fort Defiance, Ariz., this formation reappears, dipping steeply in the same direction. From this point it trends southward, being crossed by the Santa $\mathrm{Fe}$ Railroad at Manuelito. From here the Mancos shale, flattening rapidly, courses southeastward, passing about 10 miles east of Zuñi village, thence southward to the latitude of Ojo Caliente, where its outcrop swings abruptly eastward for a few miles. From this point it courses northward, the rocks dipping steeply to the east through Ramah and Nutria and on beyond the horizon in the "Hogback" east of Gallup. Northeast of Gallup the strike, including that of the Mancos shale, again changes, in this case to the east, the shale occurring in continuous outcrop a few miles north of the Santa Fe Railroad until it passes beyond the limits of the area under discussion. Throughout its outcrop the shale at this horizon is characteristically the same, varying only in its thickness, which ranges from 750 feet to more than 2,000 feet.

South of Jewett the Lewis shale covers a rather limited area, finally occupying a thickness of only 150 feet on Rio Chaco east of Crozier. Its apparent quality, so far as concerns its uses considered in this paper, is the same throughout its occurrence.

Within the area outlined by the outcrop of the Mancos shale, outside of the three districts already discussed, many beds of shale and fire clay were noted at numerous places. These beds are of variable thickness and quality, but doubtless many of them have properties that fit them for use in the manufacture of clay products.

Within the limits of the field under discussion many clays of the varieties classed as plastic clays were noted. Among these is what is 
commonly known as adobe clay, usually of residual origin, which is almost universally used by the Mexican inhabitants of the region in the manufacture of sun-dried brick to be used in constructing their buildings. In many places within the field timber is scarce or entirely absent, and building stone is not at hand. Consequently this adobe clay is of great value as a building material. The Indians of the Navaho Reservation use it to a large extent as a mortar and plaster in their stone huts. That the Aztecs successfully used this same material as a mortar in their cliff dwellings and other buildings is attested by its presence in the many ruins of these dwellings that are now scattered over the greater portion of the area. In many of the cliff-house ruins, at places well protected from the weather, this clay mortar is evidently as firm and coherent as when the houses were built, centuries ago. 


\title{
KAOLINS AND FIRE CLAYS OF CENTRAL GEORGIA. ${ }^{a}$.
}

\author{
Bу Отто Vеatch.
}

\section{INTRODUCTION.}

Character.-Throughout the Cretaceous formations of central Georgia there are remarkable deposits of pure sedimentary kaolins and fire clays of great thickness. The occurrence of white clays throughout the fall-line region has been known for many years, but the quality and extent of the clays and their availability as the basis of large industries are being but slowly recognized. The valuable clays vary from the purest, soft; flour-like kaolin to the hardest, refractory, flint fire clay, and the beds range in thickness from 6 to 35 feet. The kaolins are suitable for use in the manufacture of porcelain, sanitary ware, encaustic tiling, etc., and the fire clays are suitable for highgrade fire brick and other fire-clay wares. On account of the sedimentary origin of the clays objection is frequently made to the application of the term kaolin to them. The clays, however, even in the unwashed state, more nearly approach kaolinite in composition than do many of the washed residual clays that aire put on the market. The term kaolin is not generic and the objection has but little justification.

The only industries within the area that utilize these clays are two plants which manufacture fire brick and a small pottery which has been established recently at Augusta, Ga., for the manufacture of porcelain. Clay mining is carried on at a number of places, and the product is shipped to fire-brick and terra cotta manufacturers, to Ohio and New Jersey potteries, and to northern paper mills. About 25,000 tons are mined and shipped annually.

Location and extent.-The clay area is located in central Georgia along the fall line and extends in a northeast-southwest direction entirely across the State. The fall line is the contact between the ancient crystalline rocks of the Piedmont Plateau and the comparatively recent soft formations of the Coastal Plain. The streams of the 
Atlantic Coastal region have falls at the points where they issue from the hard crystalline rock into the soft Coastal Plain formations, and a line connecting these points has therefore been called the fall line. The clays to be described are confined to a narrow belt of Cretaceous strata along the fall line and do not at any point extend more than 30 miles south of it. The eastern belt of clays, between Macon and Augusta, ranges in width only from 3 to 15 miles. Between Macon and Columbus the clays are also confined to a narrow strip, only a few miles wide. Just west of Macon, however, and near Fort Valley valuable clays are found throughout an area having a north-south width of about 30 miles.

\section{GEOLOGY.}

Formations containing clays.-As above stated the clays occur in strata of Cretaceous age. The Cretaceous deposits in Georgia lie in contact with the metamorphic and crystalline rocks of the Piedmont Plateau and extend entirely across the State. The greatest development of the Cretaceous is in west-central Georgia, between Ocmulgee and Chattahoochee rivers, where it aggregates, perhaps, 2,500 feet in thickness. East of Ocmulgee River and between Macon and Augusta only what is probably the lower part of the Cretaceous is exposed. It is confined to a narrow strip and is in many places overlapped by tongues of Eocene strata and obscured by superficial deposits of Lafayette and Columbia sands. The detailed stratigraphy of the Cretaceous in Georgia has not been worked out. It may, however, be divided into Lower Cretaceous (Tuscaloosa or Potomac) and Upper Cretaceous.

Tuscaloosa formation.-The Tuscaloosa formation, which contains the valuable clays of the State, probably occupies the same geologic position as the Potomac of Virginia and Maryland and as the Raritan of New Jersey, which contains the valuable clays of that State. It can be traced directly into the Tuscaloosa formation in Alabama, where it also contains valuable deposits of white clay. In South Carolina ${ }^{a}$ the formation has been named Hamburg and has been subdivided into Lower Hamburg and Upper Hamburg. On account of the variable character of the formation in Georgia it will probably be difficult to subdivide and map the formation accurately. Recent field work done by the writer has made it possible roughly to subdivide that part of the formation lying between Macon and Augusta into a lower sand member and an upper clay member, which probably correspond to the Lower Hamburg and the Upper Hamburg of South Carolina, the upper member in both States containing the most valuable clays. For convenience of description the Tuscaloosa will be divided into an eastern belt and a western belt, $\mathrm{O}^{\circ}$ cmulgee River forming the dividing line. The Tuscaloosa is composed chiefly of crcss- 
bedded quartz and mica sand, gravel, and white clay. The lower member of the eastern belt, or that part east of Macon and the Ocmulgee River, consists of coarse, clayey gravel and sand, which near the contact with the crystalline rocks is locally an arkose and is at many places indurated. The clayey sand is generally cross bedded and has a characteristic pink color. It contains lenses of kaolin of remarkable purity, but most of these are of small extent, and the kaolin of which they are formed is likely to vary in texture or to grade into sand within a short distance. The upper member of the Tuscaloosa, in the eastern belt, is composed largely of clay in beds 10 to 35 feet thick, which is exposed at various places throughout a distance of approximately 90 miles. These clays vary from pure white and creamcolored gritless kaolins to semihard and flint fire clays. The clays of

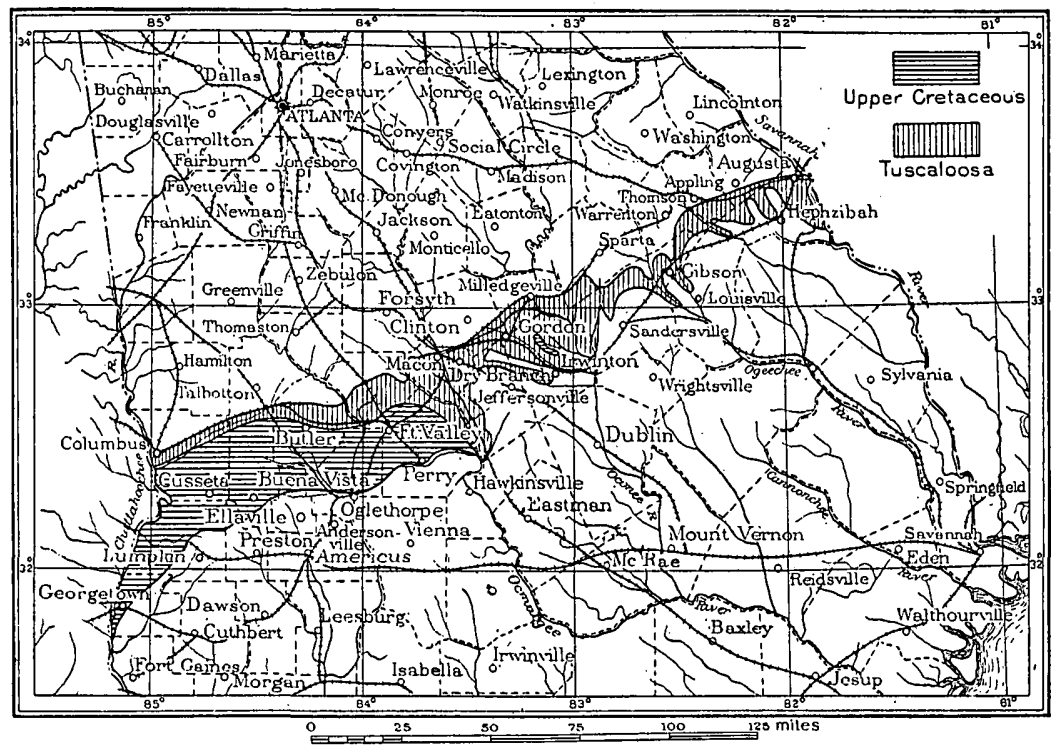

FIG.10.-Map showing exposures of Cretaceous rocks in Georgia.

this formation are for the most part white or light colored, but in places may be mottled red, yellow, or purple by iron oxide. The formation is largely obscured by overlying deposits of Eocene sands and clays, exposures of clay occurring only where stream erosion has removed the overlying strata and in artificial cuts. The beds vary in thickness and are associated with more or less kaolinic sand. The thickness of the Tuscaloosa of eastern central Georgia varies from 50 to 500 feet.

The western belt of the Tuscaloosa, or that part lying between Macon and Columbus, is for the most part similar lithologically to the eastern belt. The subdivision of the eastern belt of the Tuscaloosa into an upper and lower member will probably not hold for that part 
of the belt lying west of Macon. At its contact with the crystalline rocks, which are schist and gneisses, the formation in this region is composed of subangular quartz and feldspar gravel; farther south these are replaced by gray and pink micaceous sand containing irregular beds of kaolin and fire clay. The kaolin beds are not so thick here as in the eastern belt, and individual beds are not so extensive. No kaolins of great value have been discovered west of Butler. The Tuscaloosa in the vicinity of Geneva, near Columbus, differs in appearance from the formation as exposed in any other part of the State. Here it is composed largely of indurated material and consists of alternating layers of indurated clay and sandstone. The clay layers here are thin, dark colored, and iron stained. The Tuscaloosa in western Georgia is overlain by Upper Cretaceous strata, whereas in eastern Georgia it is overlain by sand and clays of Tertiary age. It is very difficult to distinguish the Tuscaloosa from the clayey sands of the Upper Cretaceous.

Upper Cretaceous.- - The Upper Cretaceous strata in Georgia are exposed in a belt, 15 to 25 miles in width, which extends westward from Ocmulgee River to Chattahoochee River. No Upper Cretaceous strata are known to be exposed east of Ocmulgee River. The strata consist of unconsolidated sands and gravel, marls, clays, and limestone. The marls and limestone are best developed along Chattahoochee River, where the greatest thickness of strata is exposed. East of Chattahoochee River the formation is predominantly sand containing lenticular layers and irregular and nonpersistent beds of clay, although one of the marl beds can be traced from Chattahoochee River eastward to a point 4 miles east of Marshallville, in Houston County. The sands are ferriferous and contain thin layers and hollow nodules of siliceous limonite. At some localities; however, there are great thicknesses of pure white, extremély fine, loose sand. No clays that are likely to be of value have been discovered in the formation except in Houston County, where white clays occur in great quantity.

\section{DESCRIPTIONS OF CLAY DEPOSITS BY LOCALITIES.}

The following descriptions do not by any means include all the localities where good clays are exposed. The aim is to describe the clay at the principal localities, in order to give some idea of its extent, quality, and accessibility.

\section{DRY BRANCH.}

Dry Branch is on the Macon, Dublin and Savannah Railroad, 9 miles southeast of Macon. Here the most extensive and purest beds of clay occur and here clay mining is most actively carried on. The clay mined is largely a soft kaolin, suitable for the paper and pottery trade. Four companies are at present engaged in active mining, 
the Atlanta Mining and Clay Company, the Georgia Kaolin Company, the American Clay Company, and I. Mandle \&.Co.

At the pits of the Atlanta Mining and Clay Company, 2 miles southeast of Dry Branch station, the clay bed is in places 25 feet thick and is composed for the most part of a plastic, soft, pure kaolin. Only 8 to 15 feet of clay, however, is worked. This clay is so pure that it is dried and shipped in the crude state, without preliminary washing: The clay has an overburden of nonindurated Tertiary sand and clay, the thickness of which increases gradually from 10 feet to a maximum of 100 feet. The clay bed as it appears in the pits is massive and jointed and is not laminated, but occurs in one solid bed. It is white to cream colored, but shows slight staining of iron and manganese along the joint planes and contains some small, yellow pseudo-iron nodules. Mining is carried on in open pits, the overburden being removed by a steam shovel. The following section shows the nature of the overburden:

Strata overlying clay bed at pits of Atlanta Mining and Clay Company, near Dry Branch, Ga.

1. Red sand ... Feet.

2. Greenish, laminated, tough clay..............................

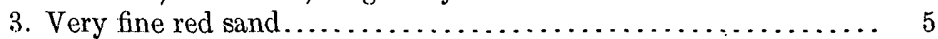

4. Green clay layer.................................. 1

5. Fine red micaceous sand, containing smutty particles of a manganese mineral. ................................... 4

6. Yellow ocherous sand ................................ 3

7. Sand containing white clay pebbles.................... 3

8. Kaolinic sand ..................................... 8

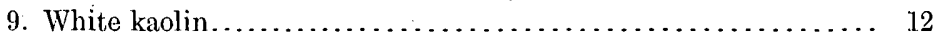

The following analysis of the No. 1 paper and pottery kaolin shows the purity of the product in its crude state:

- Analysis of kaolin from pits of the Atlanta Mining and Clay Company.

[E. Everhart, analyst.]

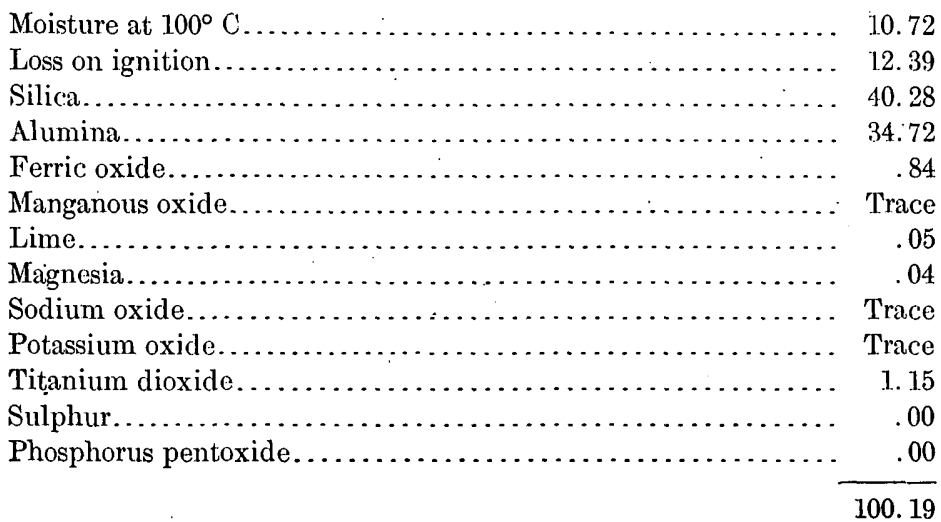


The kaolin contains-

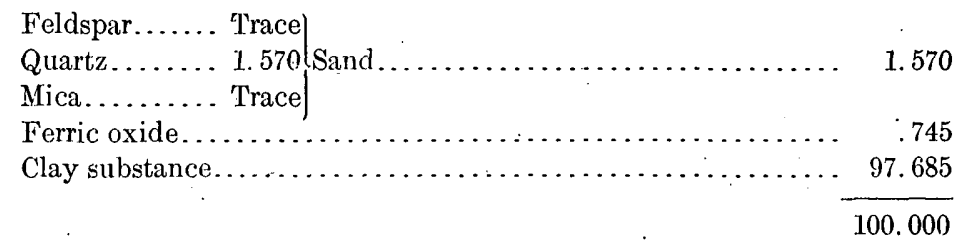

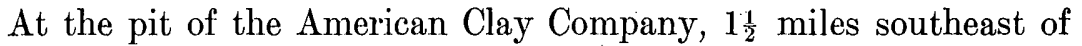
Dry Branch, the clay is in one massive bed 18 feet thick. It is soft drab to cream color and yellow, jointed, and very free from "grit" or mechanical impurities. It is overlain by 20 to 30 feet of red, yellow, and gray sand, which near the pit increases to a maximum of 80 feet. The clay is shipped without washing and is used entirely as a filler in the manufacture of paper. When dried it whitens in color, and when pulverized has the feel and.color of low-grade wheat flour.

The Georgia Kaolin Company operates a mine 2 miles east of Dry Branch. The bed is 18 feet thick. The upper 5 or 6 feet of the bed is hard and contains manganese stains and small curious fingers of sand. The lower part of the bed is soft, plastic, gray or cream colored, and remarkably free from grit. A rational analysis shows no quartz sand and only a very small percentage of mica. The clay is suitable for pottery and paper uses. The following is an analysis of the purer clay found here:

Analysis of kaoiin from pit of the Georgia Kaolin Company.

[E. Everhart, analyst.]

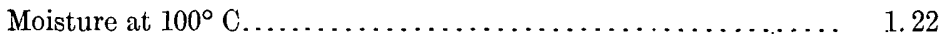

Loss on ignition .................................... 13.46

Silica......................................... 44.76

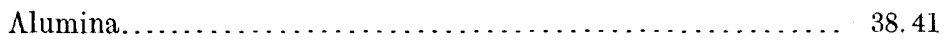

Ferric oxide.....................................

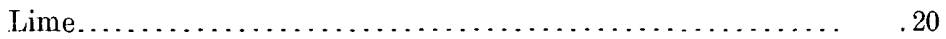

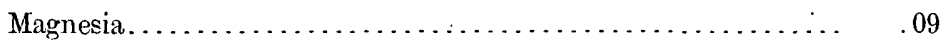

Sodium oxide....................................... . 09

Potassium oxide..................................... $\quad .35$

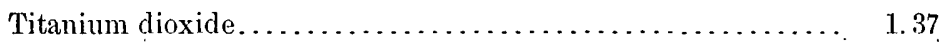

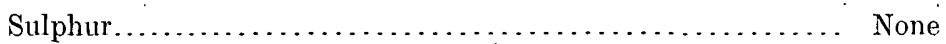

Phosphorus pentoxide........................... None

The composition of the kaolin is-

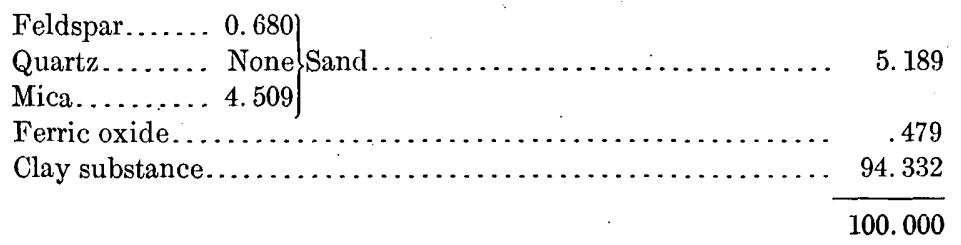


Physical tests ${ }^{a}$ show that the clay requires 21 per cent of water to develop a plastic mass, and that when made into air-dried briquettes it has a tensile strength of 50 to 55 pounds per square inch, and air shrinkage of 5 per cent. The clay when burned to cone 8 , or about $2,354^{\circ} \mathrm{F}$., was pure white, without trace of a yellowish tint. At $3,100^{\circ} \mathrm{F}$. the material showed no signs of fusing.

At the pit of I. Mandle \& Co.; 2 miles south of Dry Branch, only 10 feet of white clay is exposed, but the bed is probably somewhat thicker and is of large extent areally. The clay here is white, semihard, and very free from quartz grains. It is too hard for a No. 1 paper clay, but is very pure and is sold crude and in bulk almost entirely for pottery use.

The clay beds at the above four localities are in the same geological position, namely, at the top of the Tuscaloosa, and in contact with Eocene sand and clay. They are parts of one persistent clay formation that ranges in thickness from 10 to 35 feet. The strata in this region are nearly horizontal, having only a very slight dip southward. The amount of overburden of the clay beds may be estimated from surface levels.

\section{MCINTYRE AND GORDON.}

In the vicinity of McIntyre and Gordon, on the Central of Georgia Railway, 22 and 30 miles, respectively, east of Macon, there are extensive beds of fire clays and some pottery kaolins. The fire clays lie at the base of Tertiary ridges and are exposed wherever the small streams have cut through the Tertiary clays and sands that form the surface rock. The clays are usually white in color and range in hardness from soft, semihard and "punky" to very hard. They are both plastic and nonplastic and show fusing points ranging from Seger cones 28 to $36\left(3074^{\circ} \mathrm{F}\right.$. to $3362^{\circ} \mathrm{F}$.). The soft clays contain more iron than the Dry Branch kaolins and are in places mottled red, yellow, and purple by iron oxide. Some of the fire clays are very hard and consist of about equal parts of quartz sand and kaolin, the kaolin forming the cementing material. Throughout this region there are peculiar "punky," white, pitted clays, which have the property of hardening slightly upon exposure. This clay is sawed from quarries and used locally for building chimneys and foundations. It possesses little or no plasticity, but is highly refractory and would be especially useful when finely ground for making fire brick. The clay beds of this region vary in thickness from 10 to 30 feet and are entirely undeveloped. 
The following are some chemical and physical tests made upon clays in this vicinity:

Chemical and physical tests of clays from beds near McIntyre and Gordon, Ga.

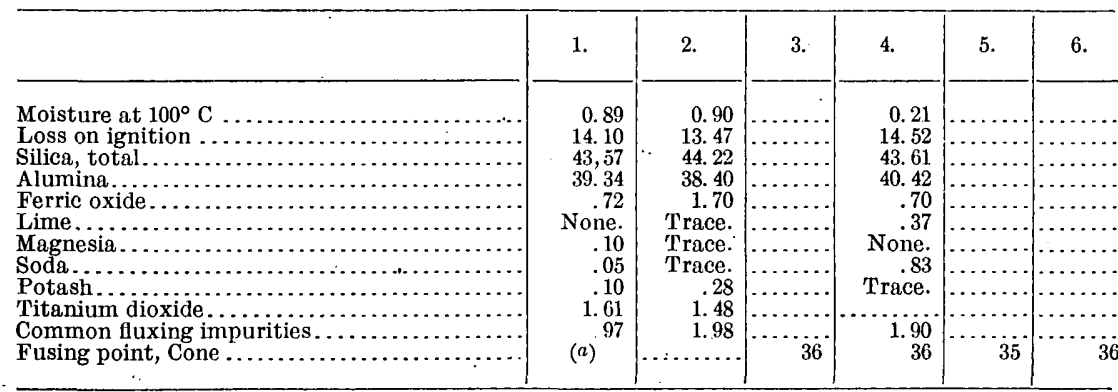

$a$ Unaffected at $3000^{\circ} \mathrm{F}$

1. Semihard fire clay, used locally as a building stone, 3 miles east of McInty re; E. Everhart, analyst.

2. Same locality as above, iron-stained soft kaolin, 4 to 15 feet thick; E. Everhart, analyst.

3. White friable clay, $1 \frac{1}{2}$ miles south of Gordon; clay bed $12+$ feet thick.

4. Cream-colored, fine-grained hard clay, 3 miles south of Gordon; clay bed 30 feet thick.

5. Clay from bed $1 \frac{1}{2}$ miles east of Lewiston.

6. Clay from bed 1 mile south of Irwinton. A very pure clay, but cracks when burned.

GIBSON.

Gibson is on the Augusta Southern Railroad, 50 miles southwest of Augusta. Large undeveloped deposits of both kaolin and fire clay occur here. The clays are in the same geologic position as the clays farther southwest-in contact with Tertiary strata and at the base of Tertiary ridges and hills. They are overlain by loose sand, green and drab clays, and occasionally by thin beds of limestone. Three miles east of Gibson there is a kaolin deposit that varies in thickness from 18 to 30 feet and has an average thickness, as determined by auger borings, of 23 feet. This bed is, for the most part, white, but contains some cream-colored and light-yellow streaks and varies considerably in its content of quartz and mica. The kaolin on the greater part of the bed could be profitably washed. Analysis shows that even in the crude state it is one of the purest kaolins found in the State. It is remarkably plastic but has low tensile strength. It burns to a dense white body at Seger cone $9\left(2390^{\circ} \mathrm{F}\right.$.), the temperature usually attained in burning white ware. Small amounts of this clay are being used for porcelain ware in the pottery at Augusta. The following analysis shows the purity of the clay:

Analysis of kaolin from Gibson, Ga.

[E. Everhart, analyst.]

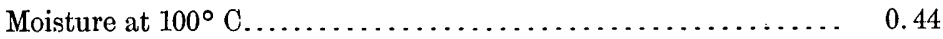

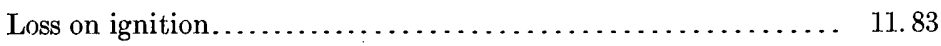

Silica............................................. 47.37

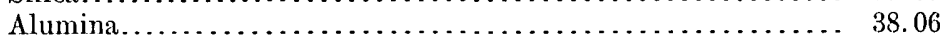

Ferric oxide........................................ $\quad .63$ 


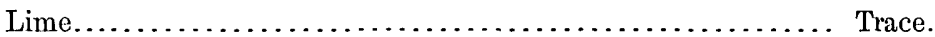

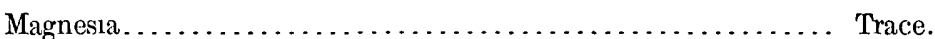

Sodium oxide.t................................... $\quad .60$

Potassium oxide....................................... $\quad .26$

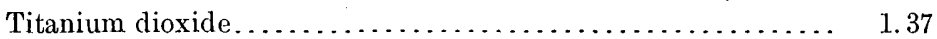

Sulphur.............................................. .04

Phosphorus pentoxide............................ Trace.

The kaolin contains-

100.60

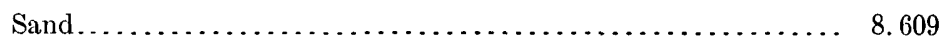

Ferric oxide........................................

Clay substance............................. 91.356

100.000

The following geological section was made along a sloping ridge at the point where this kaolin outcrops:

Section along ridge 3 miles east of Gibson, Ga.

Foet.

30

1. Red, cross-bedded sand capping the ridge.

fossils........................................ 20

3. Thin-bedded, soft, fossiliferous limestone.............. 5

4. Calcareous clay and sand........................... 5

5. Kaolinic quartz sand; contains large pellets of white clay and disseminated kaolin; belongs to the Tuscaloosa formation..... 15

6. Kaolin, stained with iron oxide near the top................ $6+$

Two miles east of Gibson there is a bed of flint fire clay 20 feet in thickness. This is a cream-colored clay, with yellow iron stains, containing 18 per cent of quartz sand and only 1.42 per cent of fluxing impurities. It is the hardest clay found in central Georgia, having a hardness of 2.5 to 3 . It breaks with a conchoidal and splintery fracture and disintegrates very slowly on exposure to the weather. No plasticity is developed even by fine grinding. It is very refractory and with a plastic clay for a bond will make excellent fire brick.

\section{HEPHZIBAH.}

The Albion Kaolin Company is mining kaolin at Hephzibah. The kaolin here is 12 feet thick, soft, free from grit, and plastic. It is in one massive jointed bed, overlain by about 20 feet of indurated and nonindurated sand and gravel, which gradually increases in thickness away from the bed. The kaolin, on account of its freedom from grit and its softness, is an excellent paper clay, and the product of the mine is shipped to northern paper mills. The clay, however, is also adapted to the manufacture of pottery. The following analysis of the crude clay represents its average quality. 
Analysis of kaolin from Hephzibah, Ga.

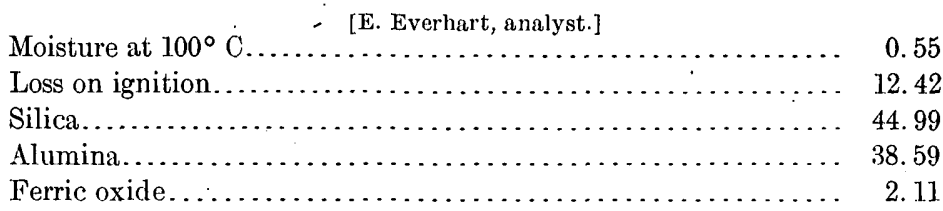

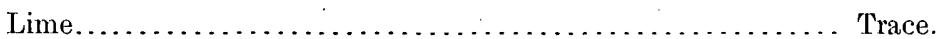

Magnesia............................................ .05

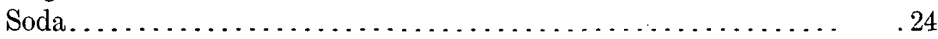

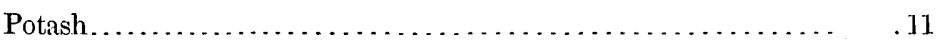

Titanium dioxide.................................. 1.04

Phosphorus pentoxide....................................

Sulphur...................................... 02

The kaolin contains-

100.25

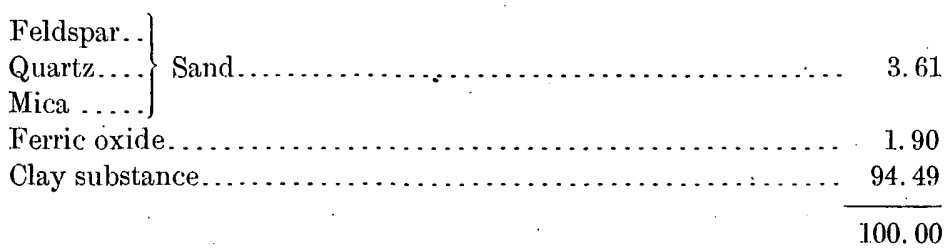

PERRY, HOUSTON COUNTY.

A fine deposit of kaolin is exposed in Upper Cretaceous strata on Bay Creek, 2 miles northwest of Perry, at various points along the base of a ridge. A shaft has been sunk into the kaolin 15 feet, and it is reported that the bed has been penetrated to a depth of 20 feet by auger boring. Within an area of 500 acres many prospect holes and wells have been put down, most of them encountering kaolin. The clay evidently occurs in great quantity, but is likely to vary in thickness. The overburden consists of very fine, variegated, micaceous sands, having a maximum thickness of 80 feet. The top of the bed, near its contact with the overlying ferriferous sands, is stained red and yellow by iron oxide. The clay is chalky white when dry and contains only a very small percentage of sand. It is probably. best adapted for use in the manufacture of white ware. An analysis follows:

Analysis of kaolin from Perry, Ga:

Moisture at $100^{\circ} \mathrm{C}$

[E. Everhart; analyst.]

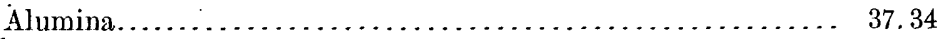

Ferric oxide....................................... $\quad .56$

Lime..................................... Trace.

Magnesia.......................................... .05

Soda............................................. .04

Potash ................................................

Titanium dioxide................................ 1.66

99.78 
The kaolin contains-

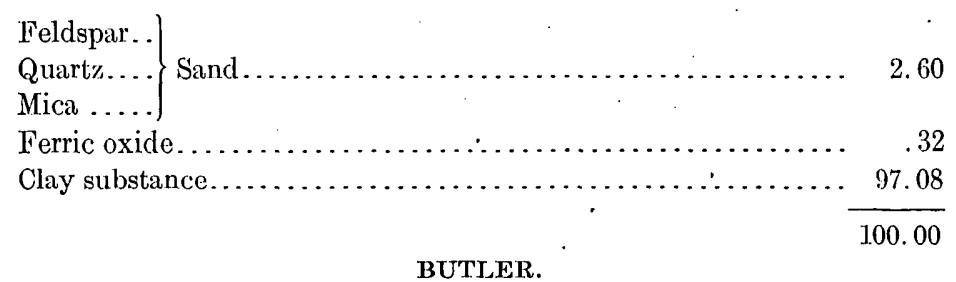

At Butler white clays occur in considerable quantity and have been mined at one locality. The clay is located in the western belt of the Tuscaloosa and is typical of the clays of this belt. A clay mine was operated for a few years at a point $2 \frac{1}{2}$ miles west of Butler, but operations there have been suspended since 1905. The clay bed mined has a maximum thickness of 20 feet and is in part sandy, but much the greater portion of it could be utilized by washing. The clay in this vicinity occurs in lenticular layers, which vary greatly in thickness within short distances. The kaolin varies in texture and may grade rapidly from pure clay into a micaceous sand. It is gray or cream colored, becoming white when dry, and is soft and plastic, but coarse particles of quartz are scattered throughout its mass. The overburden consists of sand and is much thinner than in most localities. It reaches a maximum of 20 feet.

The clay was run through an air separator and shipped largely as a filler for wall paper. A small amount was also shipped to the cotton mills at Columbus, Ga., where it was used for sizing cotton cloth.

A sample of this clay was analyzed after it had been run through a pulverizer and air separator.

Analysis of kaoiin from Butler; $G a$.

[E. Everhart, analyst.]

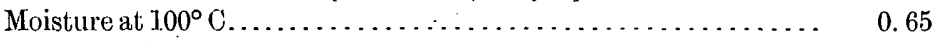

Loss on ignition.................................... 13.26

Silica..................................... 47.03

Alumina........................................... $\quad 37.37$

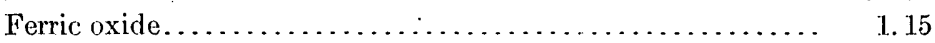

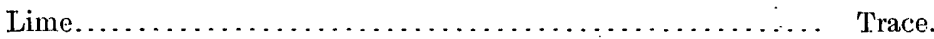

Magnesia........................................ $\quad .06$

Sodium oxide..................................... $\quad .17$

Potassium oxide ..................................... 18

Titanium dioxide................................ $\quad .17$

The analysis shows that the clay contains-

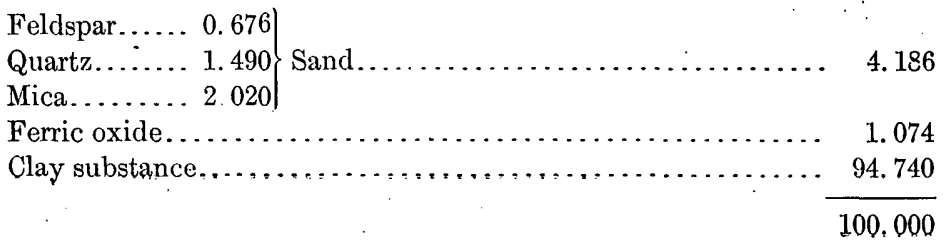


In the following table of analyses and tests the kaolins of Georgia are compared with the best known domestic and foreign kaolins. The Georgia, South Carolina, and Florida clays are sedimentary in origin; the remaining five are residual clays.

Table showing composition and comparative tests of clays.

\begin{tabular}{|c|c|c|c|c|c|c|c|c|c|}
\hline & 1. & $2 .^{\cdot}$ & 3. & 4. & 5. & 6. & 7. & 8. & 9. \\
\hline Silica. & 47.37 & 44.76 & 45.39 & 45.02 & 45.70 & 46.24 & 46.87 & 48.26 & 47.50 \\
\hline Alumina. & 38.06 & 38.41 & 39.19 & 38.98 & 40.61 & 36.25 & 38.00 & 37.64 & 37.40 \\
\hline Ferric oxide............. & .63 & .63 & .45 & .77 & 1. 39 & 1.64 & .89 & .46 & .80 \\
\hline Iime................... & Trace. & .20 & .51 & .03 & .45 & .19 & Trace. & 06 & Trace \\
\hline Magnesia................ & Trace. & .09 & .29 & .07 & .09 & .32 & .35 & Trace. & $\ldots .$. \\
\hline $\begin{array}{l}\text { Potash } \ldots \ldots \ldots \ldots \\
\text { Soda. } \ldots \ldots \ldots\end{array}$ & $\begin{array}{l}.26 \\
.60\end{array}$ & $\begin{array}{l}.35 \\
.09\end{array}$ & .83 & 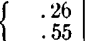 & 2.82 & 2.53 & 1.22 & 1. 56 & 1. 10 \\
\hline Titanium & 1.37 & 1. 37 & & .85 & & & & & \\
\hline Water... & a 11.83 & 13. 46 & 14. 01 & 13.58 & 8.98 & 1.3. 53 & 12. 70 & 12.02 & 12.48 \\
\hline Moisture & .44 & 1.22 & $\therefore 01$ & & .35 & & & & \\
\hline Fluxes... & 1.49 & 1. 36 & 2.08 & 1. 68 & 4.75 & 4. 70 & 2.46 & 2.08 & 1.90 \\
\hline $\begin{array}{l}\text { Fusion ............. } \\
\text { Color burned ..... }\end{array}$ & White & $3,100^{\circ} \mathrm{F} .+$ & & Whito & $2,700^{\circ} \mathrm{F}+$ & $\cdots$ & $\cdots$ & $\cdots$ & $b 27+$ \\
\hline Color burned. & W nite. & White. & $\begin{array}{l}\text { Nearly } \\
\text { white. }\end{array}$ & White. & white. & $\ldots \ldots$ & & $\ldots \ldots$ & $\cdots \cdots$ \\
\hline Tensile strength. & Low. & 50 to 55 & 65 & 13 & $20^{\circ}$ & & & & \\
\hline $\begin{array}{l}\text { Air } \\
\text { Fire }\end{array}$ & $10 \%$ & $\begin{array}{r}5 \% \\
15 \%\end{array}$ & $15 \%$ & $10 \%$ & $6 \%$ & $\cdots$ & & .. & $\cdots$ \\
\hline Clay substance.... & 91.33 & 94.33 & & 96.95 & 96.81 & 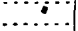 & & & 99.00 \\
\hline
\end{tabular}

$a$ Contains 0.04 per cent sulphur.

$b$ Cone.

1. Kaolin from Gibson, Ga., unwashed.

2 Krolin from Dry Branch, Ga., unwashed.

3. Ball clay from Edgar, Fla., washed.

4. Kaolin from Aiken, S. C., unwashed.

5. Kaolin from Webster, N. C., washed.

6. Kaolin from Brandywine Summit, Pa., washed.

7. Zettlitz, Bohemia, washed.

8. Cornwall, England, washed.

9. West Cornwall, Conn., washed.

\section{CLAY MINING.}

Clay mining is carried on actively at two localities, Dry Branch and Hephzibah, and small amounts of clay are mined at Griswoldville, Lewiston, and Carrs Station. No washing plants are installed at any of these places, the clay being shipped in the crude state. At Dry branch and Hephzibah the kaolin is placed in long drying sheds, and after about three weeks of air drying is ground into flour or into small lumps, and is shipped in sacks, each holding about 200 pounds, and in wooden casks each holding approximately a long ton. The overburden is removed by hand labor and by steam shovels, and mining is done by the open-pit method. Both the overburden and the clay are soft, and no blasting is required. The installation of washing plants and steam shovels will materially increase the profits in mining these clays, for a product of greater purity and uniformity can thereby be procured, all the material that now forms waste can be utilized, and larger quantities of clay can be handled. The enormous profits that may accrue from some other forms of mining are not to be expected in clay mining: but by properly handling the clay and by economical management a reasonable profit on an investment can be obtained. 


\section{CLAY RESOURCES OF THE ST. LOUIS DISTRICT, MISSOURI.}

1 By N. M. Fenneman.

In the year $1905 \mathrm{St}$. Louis produced and sold about $\$ 5,000,000$ worth of clay products, this being about one-thirtieth of the entire output of the United States. The products here counted comprise

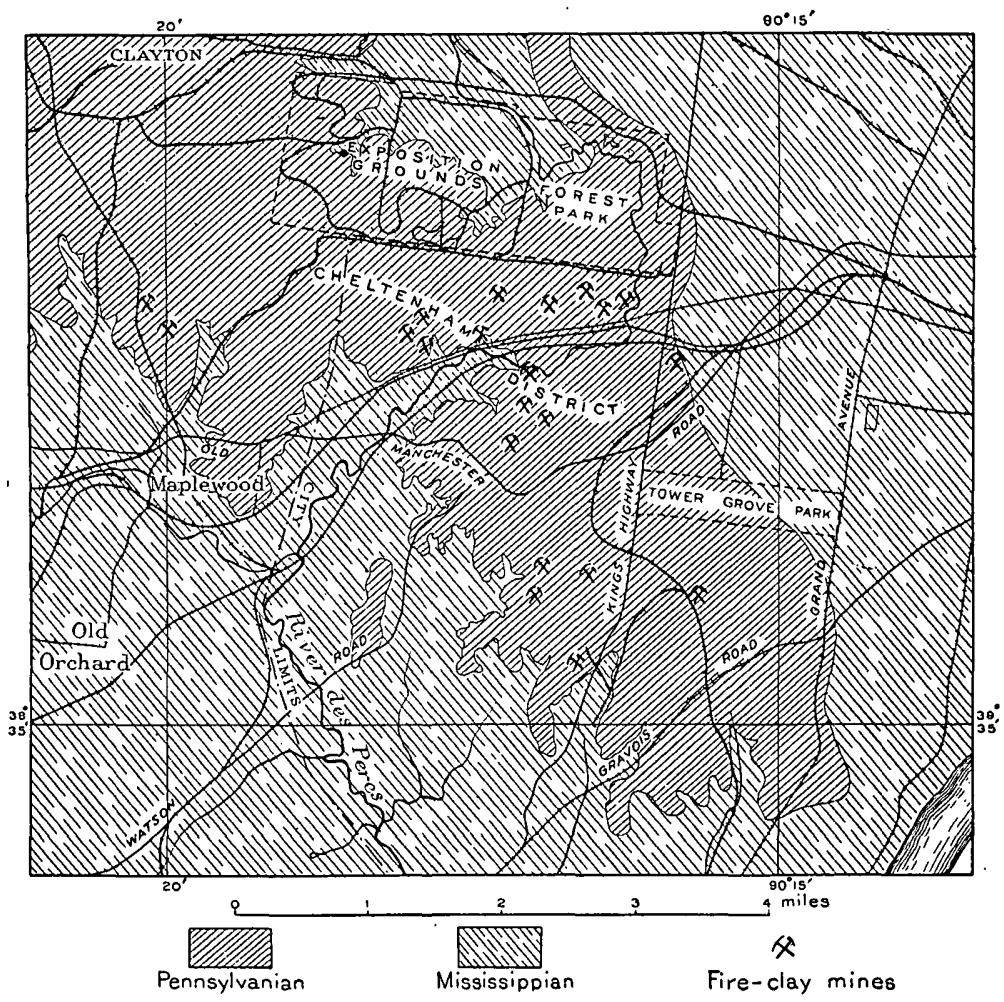

FIG. 11.-Map of Cheltenham district and vicinity, St. Louis.

those of fire clays, shales, and brick clays. Inasmuch as a very large proportion of the total consisted of fire-clay products, and these were derived in large part from a single section within the city limits, it may be seen that St. Louis is one of the most important centers of the clay industry. 
FIRE CLAYS.

CLAYS AT CHELTENHAM.

The area from which fire clays are derived has its center in a section of the city known as Cheltenham, lying south of Forest Park. It extends about 4 miles southeastward, in a tongue about 2 miles wide, and westward to a line running south from Clayton. An examination of the geological map (fig. 11) will show that this area is an extension or peninsula of the Pennsylvanian coal measures. The clay is mined very much after the manner of coal mining, both shafts and slopes being used. The depth below the surface is generally between 60 and 100 feet.

STRUCTURE AND DISTRIBUTION.

The geologic feature to which the presence of the fire clay within the area named is mainly due is a faint synclingl basin, whose center is not far from the southeast corner of Forest Park. North and east of this point there are no mines. Certain small variations from the general structure here described are probably due to minor folds; which are too small to be reduced to system with any data now obtainable. The lowest level from which the clay is mined is 404 feet above sea level, this being within the bend of the Des Peres River, near the southeast corner of Forest Park. From this point the elevation of the bed increases both to the west and to the south. The highest known level of the clay is 494 feet, in the Van Cleave mine, about 1 mile northwest of the insane asylum, near the intersection of the old Manchester and Watson roads. West of that point the strata are affected by a gentle anticline, over which the Des Peres River flows southwestward, the combined effects of the folding and erosion being to erode the clays from this area. Similar conditions on the east and south of the productive area have caused the complete erosion of the clay-bearing series.

In so far as system is discernible in the gentle folding, all axes seem to have a northwest-southeast direction. The productive area south of Clayton lies in a gentle syncline parallel to the one above mentioned, the two axes being 4 or 5 miles apart.

STRATIGRAPHY.

Within the area named, the Pennsylvanian coal measures lie unconformably on the St. Louis limestone of the lower Carboniferous. These coal measures are generally less than 100 feet thick. It is not probable that the beds here present represent the base of the system. They consist mainly of shales and clays, but comprise subordinate beds of limestone. At the base is a thin though persistent sandstone forming the floor of the fire clay mines, all of which are in the very persistent overlying bed of fire clay known as the "Cheltenham seam." 
The same gentle downward folding that has resulted in the preservation of the fire clays from erosion has preserved a few thin beds of coal. One of these, which is of small areal extent and has a maximum thickness (in this part of the field) of perhaps $1 \frac{1}{2}$ feet, lies immediately above the fire clay. Another, equally small, with a maximum thickness of 4 to 6 feet, lies 40 to 50 feet higher. The early history of the city shows that both of these were once mined, and although their content was such as would now be considered insignificant, their influence on the early development of St. Louis industries was great. They are not now mined, except incidentally, in mining the clay.

\section{SECTIONS.}

The details of sections showing the beds passed through in sinking shafts would be of little value because of the local character of some of them and the variation in the thickness of all. A comparison of many sections, however, shows certain more or less constant features as follows:

\section{Generalized section of coal measures.}

1. Soil, loess, and clays of variable thickness.

Ft. in.

2. Weathered limestone ("tumble rock")............... $0-4 \quad 0$

3. Pipeclay, etc.-maximum.................... $0 \begin{array}{lll}-15 & 0\end{array}$

4. Coal (local) ................................. $0-6 \quad 0$

5. Limestone or "very hard blue rock," often blasted with dynamite................................. $3-15 \quad 0$

6. Red and blue clays, "keel," pipeclay, etc.............. $13-36 \quad 0$

7. Coal (very local) ............................... $0-16$

8. "Roof," consisting of dark shaly sandstone or arenaceous shale, often preserving "weeds".................. $1-70$

9. "Clod," an impure clay, liable to fall down (local)..... $0-8$

10. Coal streak (very local)........................ $0-3$

11. Fire clay-Cheltenham seam..................... $2 \frac{1}{2}-12 \quad 0$

12. Light-colored sandstone with pyrite crystals and ferruginous nodules, commonly forming the "floor".......... $1-9 \quad 0$

13. Limestone containing red cherts.

As illustrations, the actual sections of two shafts are given below:

Section at Jamieson-French mine, $1 \frac{1}{2}$ miles south of Clayton.

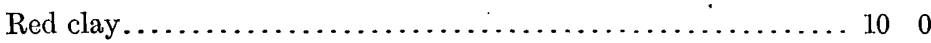

"Gravel".......................................... 10

Limestone fragments in clay....................... 30

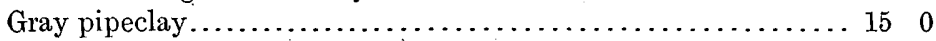

Very hard limestone................................. 60

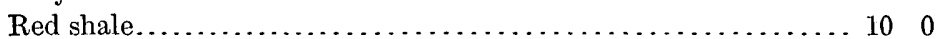

Soft black shale .................................... 30

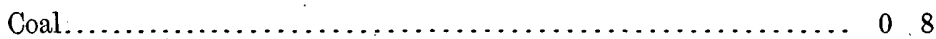

Black sandy shale................................ 16

Fire clay_Cheltenham seam; good clay taken out............ $88^{\prime} \quad 6$

Depth to floor..........................., , ..... $73 \quad 8$

Bull. $315-07-21$ 
Beneath the good fire clay are several feet of green or iron-stained clay not mined. Beneath this is pyritiferous sandstone of unknown thickness, probably at least 6 feet. At an outcrop one-half mile to the south this sandstone is underlain by limestone containing large red cherts.

Section at Krümmel and Büchner mine, Columbia avenue and Woods street.

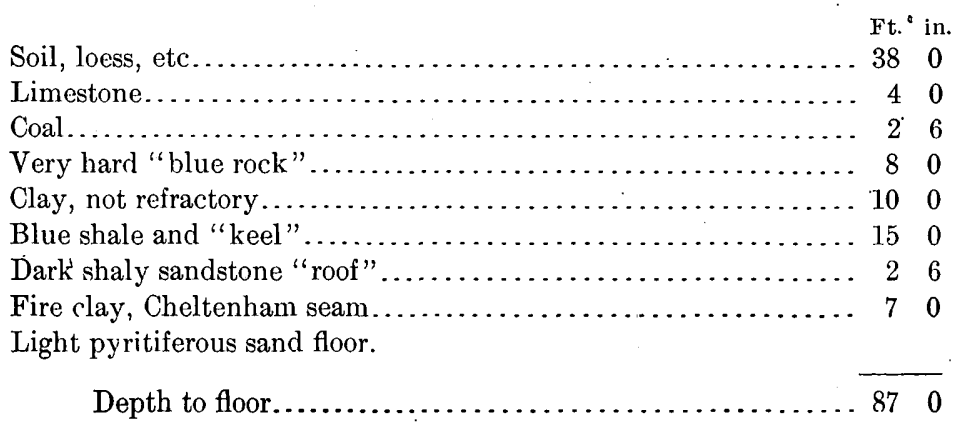

THIOKNESS OF FIRE CLAY.

The thickness of the main or Cheltenham seam may vary from 1 to 12 feet within a small fraction of a mile; it rarely if ever pinches out entirely. Most of the mining is done where the thickness ranges from 3 to 8 feet; where it exceeds that amount, as at the northeast corner of Cheltenham, the mining is generally limited to about 8 feet from the best part of the seam. Near the center of the area, which is near the Laclede mine or within 1 mile to the south of it, the seam generally ranges about 7 feet in thickness, all of this being good clay and taken out. The seam is mined at places where it is only $2 \frac{1}{2}$ feet thick. The common belief is that where the seam outcrops it is increased in thickness by weathering. Along the Des Peres River through Cheltenham its thickness is perhaps 1 foot, being from 12 to 15 per cent of the original thickness.

ROOF.

The variable thickness and changeable character of most of the beds above the clay are unimportant, but the character of the roof is a matter of much concern. Bed No. 8 in the above general section is the bed which in all mines supports the overburden and under which all posts must be set. This rock is generally sufficiently strong to span all entries and rooms, but breaks off short and falls, allowing the overburden to fall in behind the line of supporting posts when the pillars have been mined out. The mining is planned with this fact in view. The roof is more apt to be too strong than too weak. In that case it fails to break short just behind the row of posts, but sinks down over a large area, squeezing the unmined clay and probably breaking the posts. 
FLOOR.

The floor of the mine is generally the light-colored pyritiferous sand, No. 12, above. Locally the pyrite is oxidized and the sand is yellow. At some places, especially where the clay seam is very thick, its basal portion is sandy and abounds in pyrite, and is poorly distinguished from the underlying bed. At places, as in the Christy mine and the Evans and Howard No. 11, this basal clay is green and very sandy, locally oxidized to yellow and brown colors. At the latter mine and at the Parker and Russell mine, west of Kingshighway, this basal clayey mass contains large red cherts, which elsewhere (as at the Laclede, Christy, and Jamieson-French mines) are found only in the underlying limestone.

This limestone is reached in a few of the mines in digging sumps, into which the mine is drained and from which the water is pumped. On account of the imperviousness of the overlying beds, most mines are practically dry until the pillars have been drawn from some portion, thus allowing settling and cracking of the higher beds.

\section{INTERRUPTIONS OF THE CLAY SEAM.}

The surface of the floor is locally affected by gentle ridges or rolls that rise from a few inches to 1 or 2 feet in a width of a few yards. One such ridge in the floor of the Jamieson-French mine reaches the roof, cutting out the clay entirely. It is known as a "whaleback." Its trend is northwest-southeast.

In several mines the roof thickens, at some places its surface being depressed almost or quite to the floor, as in the Hume mine, south of the Insane Asylum, where a band about 200 feet wide trending northeast-southwest is thus affected. In this mine, as in a group of mines near the southeast corner of Forest Park, the lower surface of the "horse" is longitudinally grooved or fluted on a large scale.

GRADES OF CLAY.

The clay seam is rarely of uniform quality throughout its thickness. Its usual variations are due to varying proportions of silica and carbonaceous matter and to the presence or absence of pyrite and other forms of iron. In the western part of the field pyrite, the chief impurity, is found mainly in the upper part of the seam. The lower clay is of the highest grade. It is probable, however, that several feet remaining as floor are equivalent to the basal portion of the clay bed in Cheltenham. In that district it is common to regard the middle of the seam as best, the top being liable to contain carbonaceous matter and the basal portion being siliceous. In the southern part of the field it is customary to speak of the clay as upper and lower, the former being of the highest grade, the latter being lighter colored and more siliceous. 
USES.

The choicest of the clay is sold for glasshouse use. At several of the mines the clay is assorted, that which is freest from impurities being sold in the raw condition for glass pots. Good clay which contains a small amount of impurity is washed and then sold for the same purpose. For brick it is not necessary that the clay be so pure. Much of the fire clay mined in Cheltenham is used without assorting for ornamental and facing bricks or is mixed with various other clays to make sewer pipe.

\section{FIRE CLAY IN OTHER LOCALITIES.}

About 9 miles northwest of Cheltenham and 3 miles east of Creve Cœur Lake the St. Louis Vitrified and Fire Brick Company operates a mine and factory. The base of the fire clay bed at this point is nearly 90 feet below the upland level. The thickness of the clay is 12 to 15 feet, 12 feet of good clay being mined. It is practically certain that this clay is at the same horizon as that mined in the city of St. Louis. This mine is within one-half mile of the western outcropping edge of the coal measures. Beneath the clay is a sandstone with ferruginous nodules; above are 6 inches of slate overlain by 18 inches of coal. Above that are 55 feet of soft shales, mostly of a red color. Essentially the same section was noted in drilling at the St. Louis Clay Burning Company's plant, one-half mile to the southeast. At this place, it is said, limestone was encountered beneath the clay. There is also a fire clay mine at Malcolm station, southeast of Creve Cœur Lake. The section there is the same, including the 18-inch coal seam.

Fire clay has long been known north of Baden, a northern suburb of St. Louis. At the shale quarry of the St. Louis Portland Cement Company the massive shales, which are mined, are underlain by from 2 to 3 feet of black shale and this by $1 \frac{1}{2}$ feet of coal, beneath which is the fire clay.

In view of the wide separation of the points at which the Cheltenham fire clay seam is mined, it is quite probable that it may be found at many places where no prospecting has yet been done.

\section{SHALES.}

A characteristic feature of the coal measures near St. Louis is its very large proportion of plastic shales. These are largely used in the manufacture of vitrified paving brick, both in St. Louis and at points farther northwest; near Creve Cœur Lake. This shale is that which appears in the sections above the fire clay, but west and north of the eity it occurs in thicker and more continuous beds, of uniform quality. At Castello and Malcolm stations almost the entire 40 to 55 feet intervening between the loess and the coal seam overlying 
the fire, clay consists of workable shale, generally of a red or brown color, but with some blue shale at its base.

Similar clays from a place 4 miles northwest of Glencoe, a station on the Missouri Pacific Railroad, about 20 miles west of St. Louis, are largely used in St. Louis in the manufacture of terra cotta and sewer pipe, though shales from this vicinity have also been used extensively for brick. Yellow and blue shales that occupy the same. stratigraphic position are extensively mined at Prospect Hill, a few miles north of St. Louis, and used in the manufacture of Portland cement, being mixed for that purpose with the St. Louis limestone.

\section{RED BRICK.}

Many yards in and around St. Louis are making red brick from the loess, which is commonly called "yellow clay." This is rarely less than 10 to 15 feet thick, and near the bluffs may be three or four times that thick. It differs in texture at different depths, the upper portion being "stronger," more clay-like, and less mealy than the main body. Partly to obtain a thorough mixture of these different grades and partly to allow some weeks or months of "sweating," thus reducing all lumps, large quantities of the loess are commonly brought in from the pits, and kept under shed for some time before using. A good grade of red brick is made, and the supply of good loess here and elsewhere is limitless. 


\section{WHITE CLAYS OF SOUTH MOUNTAIN, PENNSYLVANIA.}

By George W. Stose.

INTRODUCTION.

The deposits here described are very siliceous clays that are associated with the wash and decomposition products of certain Cambrian strata of South Mountain. They have been actively mined in the vicinity of Mount Holly Springs, Pa., 6 miles south of Carlisle, where they are of unusual thickness and purity. These deposits have been previously described by T. C. Hopkins in an exhaustive report on the clays and clay industries of Pennsylvania ${ }^{a}$ from which some of the data in this paper are taken. Several new mines have been opened since that report was prepared, and the mine and plant of the Philadelphia Clay Company, which is the largest mine in the region and was formerly closed to visitors, was thoroughly inspected by the writer.

\section{TOPOGRAPHY AND GEOLOGY.}

South Mountain forms a rude arc of a circle curving from Potomac River at. Weverton north and east to Susquehanna River south of Harrisburg. It is composed of several parallel ridges and intervening steep-sided longitudinal valleys. The larger part of the drainage of the mountain area passes westward through rugged water gaps into the Cumberland Valley, a low rolling limestone valley 10 to 15 miles wide, part of the great Appalachian Valley that extends from northern Pennsylvania to central Alabama.

The mountain ridges are composed largely of hard sandstone or quartzite and the longitudinal valleys of interbedded shale. These rocks are of Georgian (Lower Cambrian) age, fossils of that age having been found by C. D. Walcott ${ }^{b}$ in their uppermost beds-the Antietam sandstone. They form an anticlinorium, with vertical or overturned dips on the northwest side. In the core of this anticline pre-

a Ann. Rept. Pennsylvania State College for 1899-1900, appendix, offic. doc. No. 21.

$b$ Bull. U. S. Geol. Survey No. 134, p. 24. 
Cambrian altered basic and acidic lavas are exposed. The Cumberland Valley is composed of Cambro-Ordovician limestones, which in the eastern part of the valley are interstratified with shales and siliceous beds, and in the western part are overlain by Utica and Eden shales. All of the rocks are closely folded, at many places overturned, and here and there faulted; and a southeast cleavage is strongly developed in the shales and softer sandstone layers of the mountain and in the limestone adjacent to the mountain.

\section{MODE OF OCCURRENCE OF THE CLAY.}

From the plain of the Cumberland Valley the mountain rises abruptly in a continuous straight ridge that is broken here and there by water gaps. The clay deposits occur at the northwestern foot of this outer ridge. In the vicinity of Mount Holly Springs they are also found on opposite sides of an interior longitudinal valley-that of Mountain Creek. The clay is associated with beds of sand and colored clays and with the wash from the mountain slope above. It is nearly everywhere accompanied by secondary deposits of iron and manganese ores. The clay was first exposed to view in mining the great iron deposits of this region twenty or more years ago, but its value has only recently become known.

One is inclined to conclude at first sight that the clay is a transported surficial deposit; that it was derived from the decomposition of argillaceous limestone and accumulated at the base of the slope by creep and stream action, and that the iron, having been leached out in the process of transportation, was deposited in the adjacent wash. Careful study, however, shows that most of the accumulations have not originated in this way, although, no doubt, the material in some places has moved down the steep slopes on which it originally lay and is more or less confused with surface wash.

The fact that on the surface the white clay has a definite relation to the upper bed of the mountain sandstone throughout the region is very significant. Almost invariably the sequence in the old mine pits and clay prospects is (1) colored plastic clay containing the iron ore, (2) white clay, and (3) sandstone. At many places the sandstone is decomposed to loose sand, which is quarried for use as building material, but is traceable. in depth to hard sandstone, the outermost bed of the mountain rock. No rock exposures occur for several hundred feet from the foot of the mountain in the vicinity of the clay mines, but limestone was reported in mine pits close to the white clay beds, and beyond much doubt the colored plastic clays in which the iron ore occurs is a residuum of argillaceous limestone. The surface relations therefore suggest very strongly that the white clay is also a residual product of some argillaceous sedimentary rock. The fragments of sandstone contained in the clay were probably thin quartzitic layers or lenses in the original rock. 
Hopkins states ${ }^{a}$ that "the white clay is the direct decomposition product of light-colored hydromica slates which occur intercalated in the Cambro-Ordovician limestone and in the Cambrian slates; sandstones, and quartzite," and mentions several places where he observed the change from clay to slate. The places specifically mentioned-Latimore and. Hensingersville-were, unfortunately, not visited by the writer. Latimore is located on the southern edge of South Mountain, in the belt of old volcanic rocks, and the clay there is undoubtedly not at the same horizon as that in the vicinity of Mount Holly Springs, - which will be referred to later.

Clear exposures showing a change from clay to hard rock were not. seen by the writer, but in several of the deeper tunnels the white clay is hard and has a banded, lamellar structure, resembling slate, and a faint greenish tint. The section in the Philadelphia Clay Company's tunnel positively demonstrates the interbedded relations of the clay. Beyond the loose rock and wash at the entrance the tunnel passes through several hundred feet of gray shaly clay and less altered hydromica schist seamed with limestone, ocher beds, hard brownish altered dolomite, soft yellow clay containing iron ore, a thick stratum of white clay, to the quartzitic wall rock. It is concluded, therefore, that the larger deposits. of white clay are original sedimentary beds directly overlying the Antietam sandstone and underlying the limestone of the valley. The "soapstone" used at Pine Grove Furnace in the manufacture of brick is a light greenish sericite schist with quartz phenocrysts, an altered rhyolitic rock similar to other schist seen in the volcanic belt, which crushes readily to a fine white clayey powder and is probably the same as the beds at Latimore, from which the local white clay described by Hopkins was derived. These volcanic schists may be the ultimate source of all the white clay, in which case the later sedimentary white beds were derived from their decomposition and were deposited near the volcanic schist outcrops in early Cambrian time. The clay sediments are certainly variable in thickness and irregular in distribution, but they are thickest in Mountain Creek valley, near the volcanic belt.

Analyses show that the white clays are very siliceous, very low in iron, and high in alkalies. Hopkins compared analyses of white clays with those of hydromica slates from which they were derived, the samples having been taken in adjoining districts, and found that the most noticeable difference was in the greater amount of potash contained in the slates. This difference is due to leaching out of the potash in the process of disintegration. Analyses of two white clays from this area and of the volcanic sericite schist from Pine Grove Furnace are given below.

a Ann. Rept. Pennsylvania State College for 1899-1900, appendix, offic. doc. No. 21, p. 11. 
Analyses of white clay and original sericite schist.

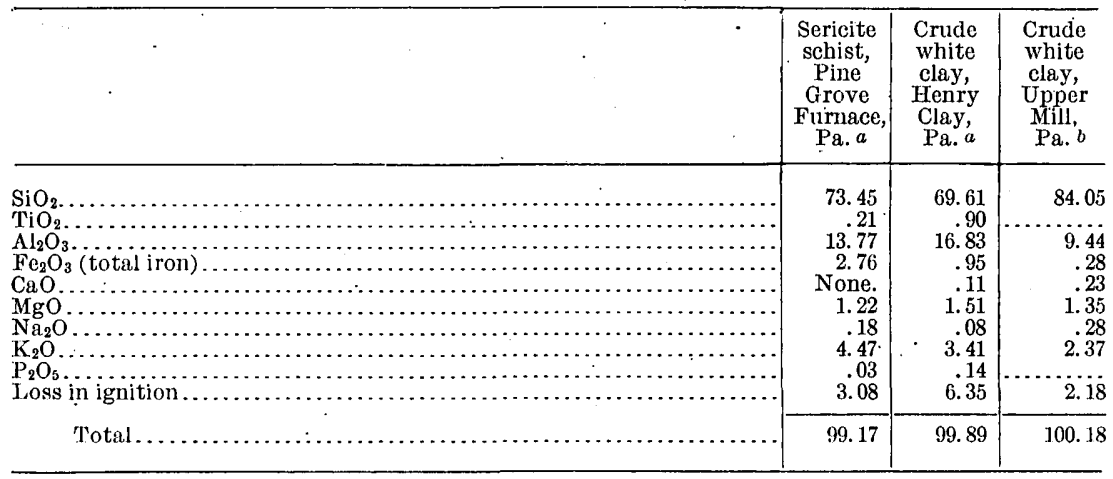

$a \mathrm{~W}$. T. Schaller, analyst.

$b$ Analyzed in the chemical laboratory at the Pennsylvania State College.

\section{DISTRIBUTION.}

White clay occurs along the west foot of South Mountain from the Maryland State line to Susquehanna River. In the southern part of the tract the beds are thin and have not been worked with profit. The southernmost opening seen was .Mr. Rock's pit, at Tomstown, 5 miles north of the Maryland line, where a small amount of white clay is associated with white sand, which is quarried for building purposes. Old ore pits are numerous in the vicinity and mining on a very small scale was in progress in an adjacent pit. East of Fayetteville clay has been obtained from near Black Gap, and prospects are now owned by Amos B. Lehman, of Fayetteville. Many pockets of the clay are found in the extensive sand deposits quarried south of the pike. Clay is reported by Hopkins along the foot of the mountain from Fayetteville north to Shippensburg, where small prospects occur, but no large bodies of pure clay have been found. The reports of the Second Geological Survey of Pennsylvania on the iron industry of this region, however, show that thick beds are associated with the ore.

The profitable clay industry is centered about Mount Holly Springs, near the east end of South Mountain. Here the clay occurs sparingly along the north face of the mountain and in greater quantity on both sides of the interior longitudinal valley of Mountain Creek. There are a number of abandoned clay workings on the north slope, on both sides of the gap. The clay is rather intimately mixed with sand and is of limited extent, and is probably in part transported from its original bedded relations. At the large sand quarries in the town of Mount Holly Springs, colored clay has been encountered which is used by the Mount Holly Brick and Clay Company in the manufacture of bricks. White clay was seen in several prospects above the Walker sand mine and in the Diven-Holly sand mine, but the deposits appear to be thin. It is also known to occur on the Stuart tract, 2 miles to the west along the mountain, where phosphorous ore (wavellite) in 
white clay is now mined by the American Phosphorus Company. The data obtainable indicate that the beds on the north face of the mountain are not thick enough to be mined profitably on a large scale.

The most extensive and valuable clay deposits occur in the valley of Mountain Creek. This valley is a syncline inclosing Shenandoah limestone, nearly all of which has been removed by erosion, or is so deeply weathered that its outcrops are concealed. It has been observed at only a few places in the valley. The clay occurs along the margins of the limestone trough next to the quartzite of the mountain. The same clay belt extends over the divide into the small valley draining eastward, where a mine is in operation. Elsewhere along the slopes of the mountain, farther east; there are scattered prospects, but only those associated with the abandoned iron pits south of Boiling Springs were visited by the writer.

\section{CLAY MINES IN OPERATION.}

The operating clay mines are all located in the valley of Mountain Creek and its extension over the low divide to the east: As stated above, numerous undeveloped prospects and abandoned clay pits occur along the mountain front in the vicinity of Mount Holly Springs, and a small amount of clay is mined at the sand pits in the town.

Cumberland Clay Company.--The eastern end of Mountain Creek valley east of Upper Mill has been extensively prospected by the Cumberland Clay Company, J. L. Musser, manager, which has opened a mine on the north side of the valley. A test shaft 150 feet deep was sunk in a prospect near the sandstone outcrop, all but 23 feet of which was reported to be in white clay. About 70 feet below this opening a tunnel runs northward into the mountain. This had been driven in about 225 feet at the time of the writer's visit, but according to reports is now in about 350 feet, and at its end a branch drift has been run about 175 feet eastward in the clay. Some of the clay, possibly a considerable portion, is white and of good grade. The shaft above will soon be connected with this tunnel as an air shaft and means of escape. It is reported that the sandstone wall in the west branch of the tunnel was pierced and found to be but $2 \frac{1}{2}$ feet thick, and that gray and white clay again occur back of it. The sandstone is probably a thin bed in the slate overlying the main sandstone.

The main working tunnel, which is fitted with a gravity tramroad, is 156 feet lower. This was 650 feet long when visited, but is now reported to be 864 feet long and to terminate in the white clay. About 800 tons of crude clay have been mined and shipped recently from this property and about 500 tons more are ready for shipment. Some of the clay is hard and compact and shows slaty cleavage, but is nevertheless of high grade.

The gravity tram conveys the clay to the plant, which was in process of construction when visited. The building, six large cement 
settling tanks, and two water tanks were already constructed. It is planned to handle the clay from washers through flotation troughs into the settling tanks by gravity. The capacity is to be 100 tons a day. The refined clay will have to be hauled by wagon nearly one-half mile to the railroad siding.

Hopkins reports that clay was mined at the old Medlar ore bank, just south of upper mill, by the Mount Holly Brick and Clay Company during 1898 and 1899 , but that work there was abandoned probably because the supply was exhausted.

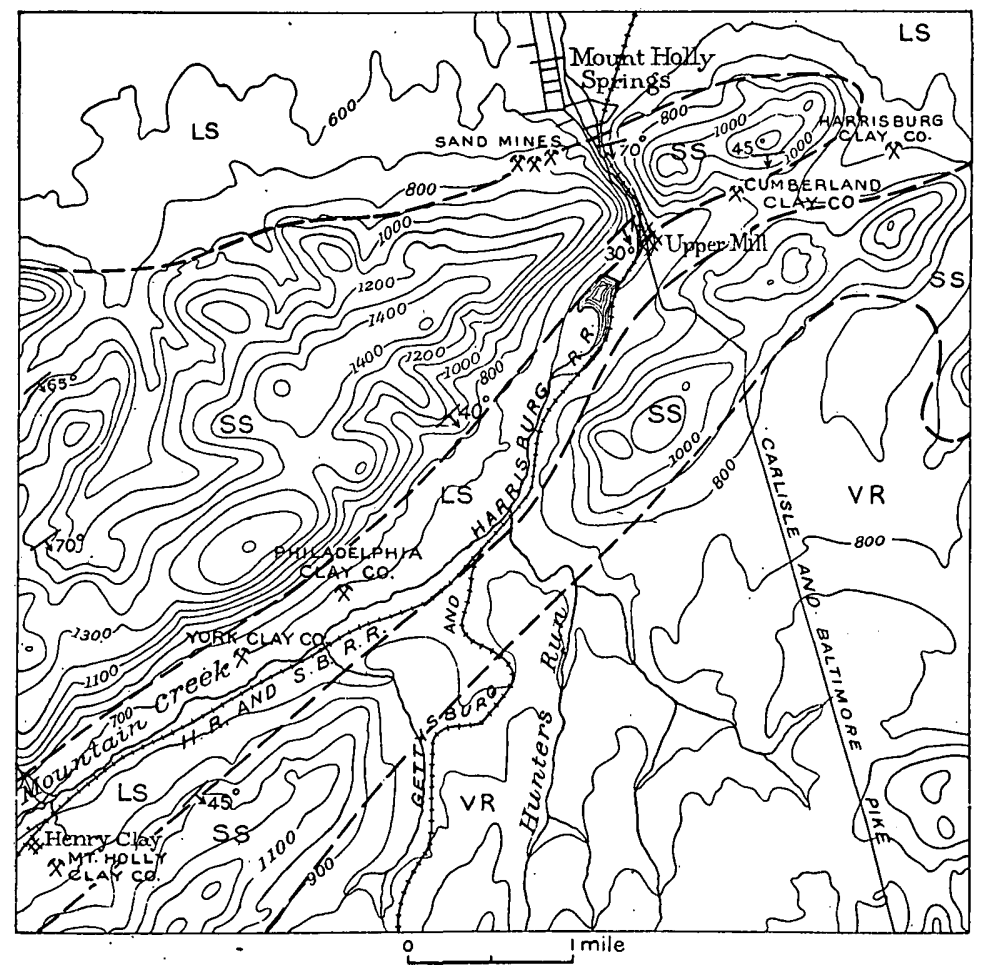

FIG. 12.-Map of South Mountain in the vicinity of Mount Holly Springs, showing the clay mines and the rock formations. VR, pre-Cambrian volcanic rocks: SS, Cambrian sandstone and shale; LS, Cambrian limestone.

Philadelphia Clay Company.-The main body of clay thus far discovered in the region occurs along the north side of Mountain Creek from the gap westward to Henry Clay. The Philadelphia Clay Company, located at the old Crane ore bank, is the most important mine in the area, and its property extends from the Mount Holly Paper Company's land at the gap to the York Clay mine, $1_{4}^{1}$ miles west. Mr. S. R. Still, the manager, courteously showed the writer the mine and works and gave all information desired.

The clay was originally prospected along outcrops in the old mine pits on the upper slopes and by a tunnel 100 feet above the present opening. The mill is located about 60 feet above the creek and is 
reached by a spur from the Hunters Run and Slate Belt Railroad. The main tunnel enters on the level of the mill and extends about 1,000 feet into the mountain to the sandstone "wall" rock. Beyond the several hundred feet of surface wash at the entrance there are 200 to 300 feet of gray shaly clay and altered sericite schist, 30 to 40 feet of yellow ocher, 10 to 15 feet of hard yellow dolomite, 65 feet of iron ore in clay, and about 200 feet of white clay, streaked with iron near the ore, but largely pure white. The clay contains grains and scattered masses of white sandstone up to 2 feet across and occasional beds. and streaks of white sand. The mountain sandstone lies back of the clay, but was not seen by the writer because the part of the tunnel that reached it had been mined out and caved in.

The white clay in this mine is at most places saturated with water and as soon as it is encountered yields water freely, which carries the clay with it. The flow of water here is incessant, but the grade of the tunnel is steep enough-1 in 12-to carry it off quickly. When ponds in old ore pits are tapped the sudden flooding of the mine is a source of danger to the workmen. It is impossible to keep a drift in the white clay open for any length of time, because the irresistible pressure of the semifluid clay breaks the timbers and a cave-in results. It is said that the life of timbers in the white clay is but three weeks. Consequently the permanent drifts for tramways are maintained in the yellow clay just outside the white clay.

The main tunnel enters normal to the mountain with a grade of 1 in 12 , and at the outer edge of the clay lateral drifts branch off in both directions. As these are to be permanent drifts for tramways they are driven in the yellow clay outside the white. From these lateral drifts crosscuts or working entries are driven at intervals of 60 feet through the clay to the wall rock.

The Philadelphia Company's method of mining is different from that in use in the other mines visited, because the deposits are peculiarly situated. They outcrop high up on the steep slopes of the mountain and stand nearly vertical, so that they can be mined like veins, by stoping up along the bedding from a tunnel beneath. Stoping is begun at the farther end of one of these entries for about 30 feet on either side until a large room is opened, when the props and pillars are removed and the clay soon crumbles or flows in. It usually continues to flow in until the clay overhead is exhausted and the wash from the surface, several hundred feet above, comes down, but sometimes further stoping is necessary. About 1,000 mine carloads are obtained from a single stope in this way, and as high as 4,000 are reported.

When the stope is exhausted the drift is robbed back and another stope is opened and worked in the same way, and this is continued 
until the entire width of the clay belt is mined. The adjoining crosscuts are then mined in the same way. By this: method a distance of 250 feet to the north of the main tunnel and 700 feet to the south have been mined out.

The white clay belt is variable in width, ranging from 120 feet to 400 feet in places, which makes the lateral tramway drifts very crooked and long, and it is the intention of the company to construct a new diagonal tunnel to intercept the farthest workings at the south and thus furnish a direct outlet for the tram cars.

The Ṕhiladelphia Company's mill and mine are the largest and best equipped in the region. The mill is a long, low building located just below the mouth of the tunnel. The mine cars bring the crude clay to the upper floor, where it is shoveled into blunger mills and churned with pure filtered mountain water by a set of oppositely revolving paddles. After thorough mixing it passes as a milky liquid or slip over inclined tables of fine wire screen, which oscillate rapidly sidewise and remove the coarser particles of sand. The slip is then run over steeply inclined screens of very fine silk bolting cloth, 200 meshes to the inch, or finer, the clay and water playing upon them from jets above. Only the impalpable clay passes through, the coarser material sliding off on the surface. This patented process produces the clay of the finest grade, but the waste from it is excessive. It is unfortunate that some use can not be made of the fine clayey sand that is now poured out on the great white dump that disfigures the landscape.

The purified slip is collected in large vats and distributed to the settling tanks, where bluing is added to whiten the clay. After standing twenty-four hours the water is drawn off from the top and is used again. The thick slip in the bottom of the tanks is pumped into filter presses and forced in until 160 pounds pressure is obtained and kept at this pressure until the water ceases to run out. These presses are made of a series of double concave iron plates, 2 feet square, with vertical grooves on the concave surfaces. A double sheet of heavy canvas is placed over the surface of the plates to let the water out and to prevent the clay from adhering to the iron. The clay slip is forced into the presses through a hole in the center of the plates, and when the spaces are filled and pressure is exerted the water passes through the canvas and down the grooves in the plates. The molded corrugated cakes of clay, $1 \frac{1}{2}$ inches thick, are conveyed by belt to a tile machine, where they are remolded into 6 -inch tiles 3 feet in length, so they will dry rapidly in the ovens, to which they are carried by small cars.

The clay is sold either in bulk, in small pieces, or pulverized, in bags. About one-half the output is pulverized. The mill has a capacity of 100 tons a day and an average production of 60 tons. it 
is equipped with 6 blunger mills, 7 oscillating screens, 104 boltingcloth screens, 17 settling tanks (some of 30,000 gallons capacity), 16 filter presses, and 15 ovens of 12 cars capacity each. The value of the clay is reported to be $\$ 5.50$ a ton. A royalty of 25 cents a ton of refined clay is paid to the owner of the land.

York Clay Company.-The mine of the York Clay Company adjoins the Philadelphia mine to the west. The mill was examined, but not the mine, as the manager, John Allen, was absent at the time of the writer's visit. The practice here has been to mine by large shaft to the maximum depth profitable, which is about 90 feet, and then abandon this for a new shaft. At the time of the writer's visit the company was operating in a round shaft 21 feet across and 50 feet in depth, with steam bucket hoist. The clay is hauled by wagon 700 feet to the mill. The company also has a tunnel 150 feet into the mountain to the clay and a drift along the bed 250 feet. Stoping had been carried 20 feet above the tunnel. A small amount of iron ore was passed through before reaching the clay. The beds seem to lie flatter here than at the Philadelphia mine, although it may be that the drifts have not yet been carried back far enough to strike the original bedded deposit.

The product is refined in the company's mill on the property. It first passes through two washers fitted with vertical paddles and then one with horizontal paddles, from which it flows as a thin slip through about 400 feet of very gently inclined flotation troughs built side by side in .50-foot lengths. The sand is deposited in these troughs and is removed by shovel, the clay remaining in suspension. The slip is further filtered through revolving wire screens and collected in settling tanks, of which there are five. After about two days the clear water is drawn off and the thick slip is forced through presses, 3 in number, similar to those of the Philadelphia Clay Company. The corrugated cakes are transferred by cars directly to the drying tunnel, which is heated by steam pipes to $190^{\circ}$. The dried clay that is not sold in bulk is pulverized in an old thrashing machine, with a cup chain attachment which delivers the powder into a vertical bin for bagging. . The capacity of the mill was reported to be between 10 and 13 tons a day.

The Mount Holly Brick and Clay Company.--Through the courtesy of the manager, Charles Blissard, much information regarding the plant and mines of this company was obtained, and the property was carefully inspected. The brick plant and clay refinery are located in the town of Mount Holly Springs, where they were constructed with the expectation that the clay mined in the vicinity of the town would furnish an amply supply for operating the refinery and that the siliceous waste and impure clay could be used in the brick plant. The supply of white clay, however, was soon exhausted, and in 1898 
the company opened up the deposits at the old Medlar ore bank, at Upper Mill, and the Henry Clay deposits, 4 miles above, on the south side of Mountain Creek. The Medlar pit has since been abandoned and the company gets its supply solely from Henry Clay, paying a royalty of 10 cents a ton, which makes the cost of crude clay at the mine about $\$ 1.30$ a ton.

The Henry Clay mine is operated by drifts from a shaft 47 feet deep in the rear of the old ore pit. The main drift runs 125 feet southeastward from the shaft, and from its end lateral drifts parallel to the mountain branch off. A large amount of pure clay is exposed in these drifts and is being mined by side entries and stoping. In a minor drift, 100 feet long, which runs northwestward from the shaft toward the valley, the white clay is mixed with yellow clay and iron ore, and the purer portions have been largely mined out. This part of the deposit may not be in its original position, for it may have moved down the slope and become intimately mixed with the overlying clay and iron ore, but the portion in the southeast drift is probably in its normal position beneath the iron-bearing clay. It appears to lie flat or to rise gently eastward and probably forms the east side of the syncline. The mine is equipped with steam hoist and tram cars. As now operated its capacity is 33 tons a day, all of which is used by the brick plant at Mount Holly Springs in the crude dried form, none being refined at present.

On the opposite side of the old ore pit, about 150 feet northeast of the clay opening, a shaft had been sunk 71 feet in ore-bearing clay, which was being mined for iron by the company, which had installed for this purpose a steam bucket hoist, an ore washer, and a gravity tramway to the railroad siding. About 15 tons a day were being mined.

The refinery at the brick plant has a capacity of 30 to 40 tons a day and is furnished with three triple vertical blungers with revolving vertical slatted grates, long flotation troughs, rotary fine wire screens, 10 settling vats, 10 presses, and a 12 -track tunnel drier. The siliceous waste extracted by the refinery process was found to be too short grained to make into bricks; in fact the crude clay itself needs a binder of plastic clay to give it body, and since the production from the mine is no more than sufficient to supply the brick plant, the refinery has been shut down for some time.

The Mount Holly Company makes an excellent hard, semivitreous brick, for which there is a ready market at the price of $\$ 20$ a thousand. The light color of the bricks, cream to light buff, makes them very desirable for the fronts of buildings, while their hardness meets the requirement for paving.

The clay from the mine at Henry Clay has the necessary ingredients to produce a vitrified brick, but has not enough body to hold its shape 
without cracking when being burned. Other clays sufficiently free from iron and manganese not to burn red must be mixed with it to give it cohesiveness. Purple clays from the sand mines at Mount Holly Springs and black clays from the northeast side of the gap are used to a small extent, but a large part of the binder comes from New Jersey and Maryland. The color of the black clay is due to organic substances, which burn off in the kiln. Because of the siliceous character of the crude white clay additional sand is not needed, but a certain per cent of grog (ground brick) is added.

The material is first ground in a dry pan, an iron cylinder with twio large iron wheels or mulls, which revolve when the bottom of the cylinder is rotated. The powdered material is conveyed from the bottom by pan elevators to a revolving sieve, from which the tailings automatically return to the dry pan. The screened mixture passes to the temperer or pug, a horizontal rotating mixer, where water in the form of. steam is added, and is then delivered by gravity to the top of a. brick machine, in which 2 vertical and 2 horizontal augers thoroughly mix the clay and destroy grain. The brick column is conveyed by a continuous belt to the cutter, the speed of which is automatically regulated by the speed of the belt. Fifteen bricks are cut at a time, and are separated by passing onto a belt moving with greater speed. They are fed by hand into two double pressing machines, where they are shaped under light pressure and stamped "Mt. Holly." If bricks are delivered too rapidly to be pressed, the surplus are returned to the pug by elevator and belt.

The bricks are dried in a 12-track steam drier 128 feet long. The cars, which carry 440 bricks each, are run into the drier at one end and removed at the opposite end, taking about two days in the passage. The temperature is $140^{\circ}$ at the ends. The bricks are finally fired in down-draft kilns with large smokestacks at the ends. The furnaces, with small smokestacks, are on the sides. Five kilns were in operation, the largest of 188,000 capacity, with a total capacity of 600,000 per month and an output of between 400,000 and 500,000 a month. The kiln is fired to cone $8\left(2,354^{\circ}\right)$ in the upper part, and the burn is completed in about a week.

Laurel Forge and Pine Grove Furnace.-At Laurel Forge, 1 mile above Henry Clay, pure white clay occurs in abandoned iron pits, where it is now mined on a small scale and used in the manufacture of brick by the Fuller Brick and Slate Company, of Pine Grove Furnace, 2 miles farther up the valley. It is mixed with pale-green sericite schist, locally called "soapstone," for the manufacture of light-colored pressed brick. Red pressed bricks are now being made from local red clay and black slate by the South Mountain Mining and Iron Company, Allen Butler, superintendent. The bricks are dry pressed, and 
although handsome and ornamental they are more absorbent than the vitrified brick made of the Henry Clay stock.

Harrisburg Clay Company.-The Harrisburg Clay Company works the only active mine outside of Mountain Creek Valley. It is in the same general syncline, however, just over the divide from that of the Cumberland Clay Company. Although it is a small plant it produces clay of very high grade, said to be as pure as any in the district.

The mine is on low ground and is operated by a short incline and tunnel running in about 20 feet to the clay and 60 feet west with the clay. It is operated by tram and steam hoist. The bed of clay appears to be rather thin and not much stoping can be done. If it is a bedded deposit, the formations must lie nearly flat in the bottom of the syncline, but. it may have moved to this position from the steep slopes above. Another tunnel was started farther south, but had not yet reached the deposit. . The clay is hauled by wagon several hundred feet to the refinery, which is equipped with 1 horizontal washer similar to the screw-and-blade type of ore washer, flotation troughs, 2 settling tanks, 2 presses, and 2 ovens of 20 cars capacity. The production of this plant is about 7 tons a day, which has to be hauled one-half mile to the railroad.

\section{USES OF WHITE CLAY.}

Paper manufacture.-Pure white clay, such as is obtained from the South Mountain factories, is used chiefly in the manufacture of paper. Wall paper, the cheaper writing papers, and all paper requiring a smooth, absorbent surface for fine printing are made in part of clay, or some other mineral, such as pulverized calcium sulphate or barium sulphate. The advantages of the South Mountain clay over other substances for this purpose is its white color, freedom from iron, fine grain, absorptiveness, and its light weight, which causes it to remain in suspension. The clay is made into a thin cream with water and a small amount of resin sizing to make it adhere to the fibers of the paper body, and is fed into the paper-machines with the pulp. The amount of clay should not exceed 10 per cent in paper for permanent publication, but for chromolithographs and publications of temporary value, 35 to 40 per cent of clay may be used, as the ink is absorbed more rapidly and the impression is clearer.

Brick and tile manufacture.-Excellent building brick of light color are made from the unrefined clay, but it requires an admixture of a more plastic clay to give it body. The potash which it contains causes it to fuse readily, and the brick acquires a semivitreous texture, which makes it both hard and impervious-qualities which adapt it to street paving and to exterior finishing. Its pleasing color also adds to its attractiveness for building purposes. The Mount Holly Brick

Bull. $315-07-22$ 
and Clay Company are engaged in the manufacture of such brick, and the Pennsylvania Tile Works, at Aspers (Bendersville station, on Gettysburg and Harrisburg Railroad), was reported by Hopkins to be manufacturing white encaustic or enameled tile. The South Mountain Mining and Iron Company, of Pine Grove Furnace, is manufacturing unvitrified pressed brick.

Other uses.-As pointed out by Hopkins, the white clay possesses many of the requirements of the potter's mixture for china ware. Although it is more siliceous, higher in potash, and less plastic than ball clay, which is the clay used in pottery manufacture, the proper mixture apparently can be readily obtained by adding to it correspondingly less silica and feldspar than is customary, the exact proportions to be determined by chemical analyses. The plasticity and cohesiveness may also need to be increased by the addition of a small amount of ball clay, as for brick manufacture.

It is known that white clay is used as an adulterant in various substances, especially in paint. Some of the clay from this area may be sold for this purpose. Hopkins also mentions that some of it is used for calcimining, for which it is well adapted. 


\section{CLAYS AND SHALES OF CLARION QUAD- RANGLE, CLARION COUNTY, PA.}

By EDwin F. Lines.

\section{INTRODUCTION.}

Both clays and shales are abundant within the Clarion quadrangle. Shales that are probably suitable for the manufacture of brick and tile are scattered over most of the region, and in some places are readily accessible to lines of transportation. The clays include both the flint and plastic varieties, but the latter have been little worked. The workable deposits of flint clay so far known are confined to the northern part of the area. This clay was formerly shipped to a considerable extent as raw material, although it had to be hauled several miles by wagon to the railroads, but it has not been mined for some time, and the old strippings are now largely covered up. There has been a recent revival of interest.in the clay, however, as a result of the beginning of the construction of a new railroad which will pass near some of the best deposits.

\section{LOCATION AND AREA.}

The Clarion quadrangle is in Clarion County, except a few square miles in its southeast corner, which extend into Armstrong County. Its north boundary passes just south of Shippensville, the south through New Bethlehem, the east a short distance within the east county boundary, the west just west of Sligo. The quadrangle comprises approximately 225 square miles, a little more than one-third the area of Clarion County.

GENERAL STATEMENT.

The rocks of the quadrangle in which the clays and shales occur are included in the Allegheny formation (or Lower Productive Coal 
Measures) and the Pottsville formation. The succession of rocks is as follows:

Relative positions of beds in Allegheny and Pottsville formations in Clarion quadrangle, Pennsylvania.

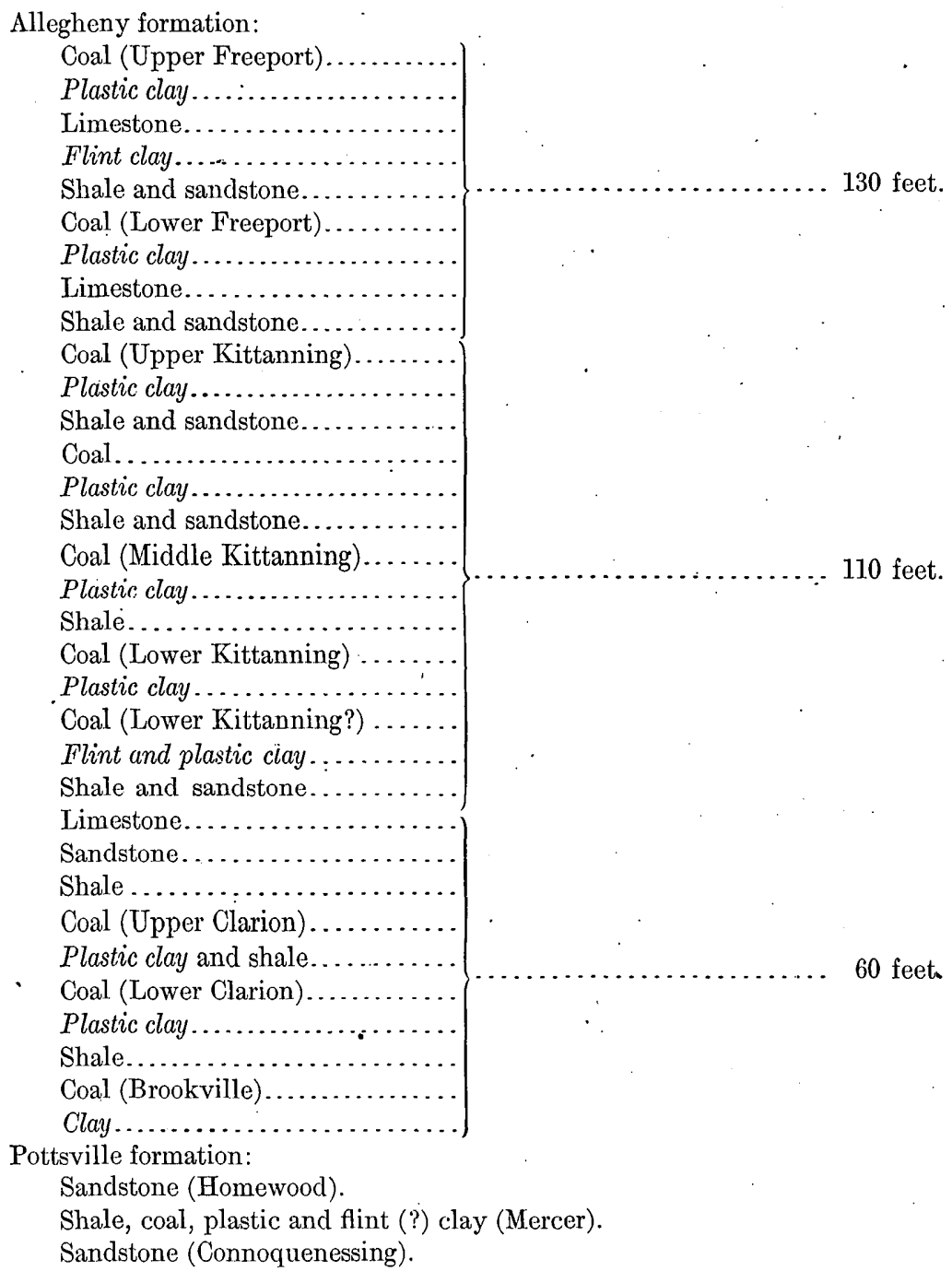

The figures showing the thickness of the groups represent a fair average but are not intended to be final.

A glance at the table shows that eleven clay horizons are associated with the same number of coal horizons, the clays underlying the coals. Two and possibly three of the clay beds contain flint clay. It will be noted that two of the coals are designated Lower Kittan- 
ning. Whether the lower seam is a split from the upper or an extra seam is uncertain. The lower coal lies from 4 to 17 feet, and in some places perhaps more, below the upper. The lower bed appears to be coterminous with the flint clay of this horizon, as the coal was not identified at any locality outside of the boundaries of the area occupied by the flint clay.

SHALES.

The only shale now in use in the area is the one below the horizon of the Clarion coal. This shale is exposed in the pit of the Canton Tile Hollow Brick Works, west of New Bethlehem, described below. Other deposits of shale that are accessible to railroads were noted as follows:

At the railroad crossing between Fairmount and Hawthorn; thickness $30 \pm$ feet.

In hill above Underwood mine at Ore Bank station, on the Sligo Branch of the Pennsylvania Rairoad; thickness $50 \pm$ feet.

In hill above Baldauf No. 1 mine, on a branch of the Pittsburg, Summerville, and Clarion Railroad; thickness $30 \pm$ feet.

The exposures just mentioned are typical and are readily accessible for examination. In general, however, smaller but numerous and widely scattered outcrops indicate that a considerable thickness of shale lies nearly everywhere above the Lower Kittanning coal.

\section{PLASTIC CLAYS.}

Mercer horizon.-Beds at the horizon of the Mercer shale outcrop. above drainage level along Clarion River, in the lower portion of Leatherwood Run, at Sligo, and just west of Mayport, but no good exposure of clay was noted at this horizon except small exposures at Mayport.

Brookville horizon.-The clay at this horizon was seen at only a few places and probably is not important.

Clarion horizon.--In some parts of the quadrangle there are two coals and two accompanying clays at the horizon of the Clarion coal. A section in a run near the schoolhouse, about 1 mile northeast of the Zion churches, shows 5 feet or more of white clay below each of the two coals. At the road fork, one-half mile south of Rockville, a 15-foot bed of clay is exposed beneath a coal blossom, probably Clarion. On

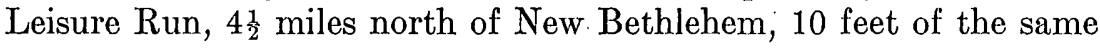
clay shows above the run and below a 16-inch coal blossom. In the vicinity of New Bethlehem this clay is now used in connection with the overlying shale by the Canton Tile Hollow Brick Company in the manufacture of hollow building brick and drain tile. 
A section made in the pit of this company is as follows:

\section{Section of pit of Canton Tile Hollow Brick Company.}

Olive fissile shale, stained red $\ldots \ldots \ldots \ldots \ldots \ldots \ldots \ldots \ldots \ldots . . \quad \begin{array}{r}\text { Ft. } \\ 3\end{array}{ }_{0}^{\text {in }}$

Carbonaceous layer (Clarion coal blossom ?)............... 4

Sandy ledge..................................... $\quad 10$

Dark-drab shale................................. 18

Drab plastic clay, soft........................... 50

Drab plastic clay, hard, siliceous....................... 50

Olive sandy shale................................... 10

Sandstone.

Kittanning horizons.-At some localities there are at least four Kittanning coals, each underlain by a clay bed. The upper clay beds so far known are unimportant. The plastic clay below the lower Kittanning coal is undeveloped, but road crops and mine sections throughout the quadrangle indicate that it is persistently present and probably of sufficient thickness for mining. Among the best road exposures is one a quarter of a mile east of Jack schoolhouse and about 4 miles northwest of New Bethlehem, where 3 feet of reddish stained clay outcrop, and one 1 mile east of Mechanicsville, where 8 feet of light-drab clay are exposed. The following sections, comprising 2 feet or more of clay, were measured below the Lower Kittanning coal in country banks and mines:

A. V. Confer coal bank, just east of Strattonville; 3 feet, apparently of good quality.

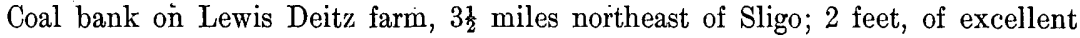
appearance.

J. K. Andrews coal bank, on James Myers farm, 3 miles northeast of Sligo; 3 feet 10 inches.

Country bank on Charles McCall farm, $3 \frac{1}{2}$ miles northeast of Rimersburg station; 6 feet, light gray clay.

Country bank 2 miles northeast of Wild Cat; $2 \frac{1}{2}$ feet, quite free from sand.

Only a partial thickness of the clay was seen at any of the above places, but the measurements are suggestive of considerable deposits of clay at this horizon. At Huey, just over the west boundary of the quadrangle, is a drift in which $7 \frac{1}{2}$ feet of clay were measured, both the top and the bottom of the section being concealed. The thickness of the clay here indicates that a good deposit may be found along the Sligo branch of the Pennsylvania Railroad wherever the clay occurs above drainage. The plastic clay from the.Lower Kittanning horizon could be prospected with a view to brick or pottery manufacture.

The other clay in use from the Kittanning horizons is the one next higher, or the Middle Kittanning. This clay is used by the Hawthorn Pottery Company in the manufacture of Bristol glazed stoneware. The supply is obtained from a stripping just north of Hawthorn. The clay here lies under 4 to 10 feet of cover and varies in thickness from 4 to 6 feet. The upper part of the bed is soft, rather free from 
sand, and has a chalky appearance due to weathering, while the lower part is harder and rather sandy and is greenish in color. The softer and more plastic portion of the bed is used as it comes from the bank in the manufacture of small pieces, but the hard portion is washed free from sand and used for large ware. At the time of the writer's visit the clay below the Lower Kittanning coal had been used experimentally, but no definite results had been obtained. The Middle Kittanning clay was formerly stripped on Town Run, opposite the opening of the No. 2 mine of the Alcola Coal Company. The quality of the clay here is reported to be excellent for pottery manufacture.

Freeport horizons.-Plastic clay occurs below each of the Freeport coals, but beds at these horizons are comparatively limited in area and few good opportunities were offered for measuring sections. The best section noted was in a country bank just west of Hickory Ridge schoolhouse, where 3 feet were exposed below the coal.

FLINT CLAYS.

Mercer horizon.-No good exposure of flint clay was seen at this horizon within the quadrangle. Just south of it, however, at Climax and St. Charles, flint clay from this horizon is used in making highgrade fire brick. $^{a}$ At one point within the quadrangle-viz, on the west side of Leatherwood Run, about 1 mile north of St. Charlesfragments of flint clay, which are probably from this horizon, have been found in a field, but several prospect holes sunk here failed to find the source of the fragments.

Lower Kittanning horizon.-Flint clay occurs below the Lower Kittanning coal in a belt that extends across the north half of the quadrangle with a width of $1 \frac{1}{2}$ to $2 \frac{1}{2}$ miles on each side of Clarion River, except in an area north of Clarion. Owing to the height of the clay in the hills, however, only a relatively small portion of the area is actually underlaid by it. The clay is persistent in its occurrence, but varies greatly in quality. It has been used to considerable extent, so its qualities are fairly well known. The best clay is light yellowish brown in color, fine grained in texture, and moderately hard. Weathered pieces are bluish gray on exposed surfaces and are easily broken. 'The following chemical analyses, made by P. H. Bates, of the United States Geological Survey's laboratories for testing structural materials, at St. Louis, Mo., indicate the quality of an average sample of this clay. 
Analyses of air-dried samples of flint clay from C. B. McQueen farm, Clarion County, Pa.

ULTIMATE ANALYSES.

\begin{tabular}{|c|c|c|}
\hline$\cdot$ & A. & B. \\
\hline Silica $\left(\mathrm{SiO}_{2}\right) \ldots$. & 58.96 & 56.46 \\
\hline Alumina $\left(\mathrm{Al}_{2} \mathrm{O}_{3}\right) \ldots$ & 25.60 & 27.69 \\
\hline Ferric oxide $\left(\mathrm{Fe}_{2} \mathrm{O}_{3}\right) \ldots$ & 3.32 & 2.55 \\
\hline Manganese oxide $(\mathrm{MnO}) . . . . . . . .$. & .07 & .09 \\
\hline Lime $(\mathrm{CaO}) \ldots \ldots \ldots \ldots$ & 70 & .42 \\
\hline Magnesia $(\mathrm{MgO})$. & .25 & .28 \\
\hline Sulphuric anhydride $\left(\mathrm{SO}_{3}\right) \ldots \ldots$ & .07 & .14 \\
\hline 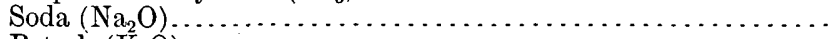 & .15 & .06 \\
\hline 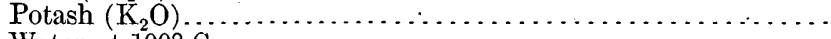 & .36 & .52 \\
\hline Water at $100^{\circ} \mathrm{C}$. & .80 & 1. 40 \\
\hline \multirow[t]{2}{*}{ 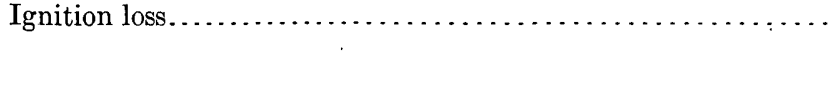 } & 9.90 & 10. 64 \\
\hline & 100.18 & 100.25 \\
\hline
\end{tabular}

RATIONAL ANALYSES.

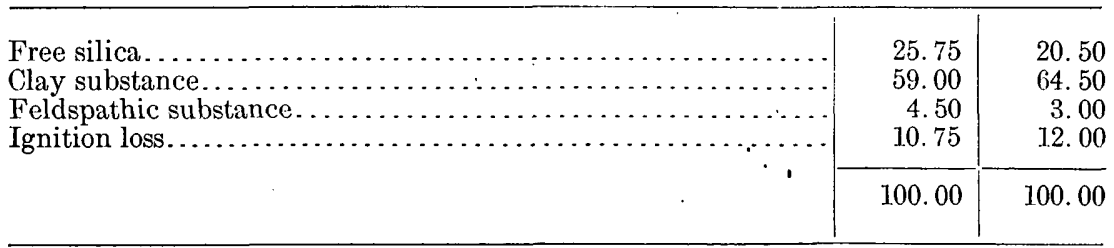

The samples thus analyzed were taken from a 3 -foot section in a new drift made by the Sligo Fire Brick Company. Sample A represents the upper 1 foot, and sample B the lower 2 feet of the section. Sample $A$ is siliceous in appearance, shows a rough surface, and breaks irregularly rather than with the conchoidal or shell-like fracture that is characteristic of flint clay. Sample B is like the type of best clay described above except that instead of being homogeneous it contains a small percentage of bluish inclusions. In some places it shows streaks that resemble bedding planes. Wherever cracks occur in the clay the surfaces formed by them are strongly stained with iron. The high percentage of iron shown by the analyses makes a good deal of the clay unsuitable for use in the manufacture of refractory materials. The clay in the bank from which the samples were taken for analysis is used by the Sligo Fire Brick Company in the manufacture of fire brick. Clay taken from below the Brookville(?) coal in the mine of the Sligo Coal and Coke Company is used as a bond. The bricks are sold principally for use in open-hearth furnaces. The reported criticism of bricks made from this clay is that while they will stand relatively high temperatures they are deficient in resistance to friction.

The quality of the clay varies from place to place.' The clay south of Clarion River appears to be, on the whole, better than that north 
of the river, and when it was stripped for shipment its price averaged 40 cents more a ton than that of the latter. In comparing these prices, however, it should be noted that shipments from the northern area probably involved the payment of higher freight rates. Clay from the area north of the river has not been used south of the Wagner and Bell farm, the reported reason being that the clay in that region contained so much iron that it is worthless as a refractory clay. In the area south of the river the best clay is reported to have been taken from the Finnefrock farm. Considerable amounts of clay have also been taken from the Miller farm, located within 2 miles of the Sligo Branch Railroad. The clay on the Finnefrock and Winkler farms, south of Piney Creek, and on the Mowry farm, north of it, is within $1 \frac{1}{2}$ miles of a new railroad now being built by the Lake Shore and Western from Franklin to Clearfield.

The following detailed descriptions of occurrences are given for the purpose of assisting prospectors:

Clarion Junction, one half acre stripping on each side of the pike.

Clarion Junction, southeast of, on F. M. Shannon farm. (Reported.)

Clarion Junction, $1 \frac{1}{2}$ miles southwest of; open pit on portion of John Rapp farm, now owned by the Niles Fire Brick Company. There is a 3-foot exposure of clay here, and an examination of the face showed that much of the clay had inclusions of impurities.

Clarion Junction, $2 \frac{1}{2}$ miles south of, on Wagner and Bell farm; old stripping uncovering about one acre. No clay was exposed here, but the clay formerly mined was reported to be of fair quality.

Piney, $2 \frac{1}{2}$ miles east of, on $\mathrm{C}$. W. Mowry farm; prospect hole revealed 3 feet or more of fair-looking clay.

Piney, 2 miles southeast of, on P. B. Finnefrock and D. C. Winkler farms; several acres of clay have been stripped, but very little is now exposed. The bed is reported to average 4 feet in thickness. In the hill on the U. S. Oppelt farm, south of the Finnefrock stripping, the clay is reported to be present also, although it has not been used.

Piney, 2 miles southwest of, on T. N. Whitman farm; old stripping in which clay was reported to average 3 feet in thickness.

Sligo, 2 miles.north of, on C. B. McQueen farm; stripping and newly opened drift; average thickness about 31 feet. A detailed description of this clay is given on p. 340 .

Sligo, $1 \frac{3}{4}$ miles north of, on J. B. Miller farm; numerous old strippings.

Sligo, $2 \frac{1}{2}$ miles northeast of; newly opened stripping on Mike Howard farm; exposed thickness 2 feet; reported thickness 5 feet. In two places just north of this point about one-half acre has been stripped.

Mechanicsville, 1 mile north of, on Clark Potter farm, now owned by Charles F. Heidrick, president of the Pittsburg, Summerville and Clarion Railroad; prospect hole shows 4 feet or more of clay of inferior quality.

In addition to the openings described above, the presence of the clay was indicated by outcrops in the roads in the following places:

Clarion Junction, 1 mile west of, on road running south to Piney. It is roughly estimated that between 10 and 15 acres in this vicinity are underlain by clay within 8 or 1.0 feet of the surface.

Manor school house, one-fourth mile east of; bed under little or no cover.

Shippensville, 3 miles south of, on road to Piney, near top of rise; bed under light cover. 
Elk City, $3 \frac{1}{2}$ miles south of; bed at top of rise under light cover.

Piney, $2 \frac{1}{2}$ miles southwest of, and Zion churches, 1 mile northeast of; a few fragments.

Piney, $2 \frac{1}{2}$ miles southeast of, on road leading to Five Points schoolhouse.

Sligo, $2 \frac{1}{2}$ miles northeast of and just southwest of schoolhouse; clay apparently of excellent quality.

Reidsburg, 1 mile north of, on road to Clarion.

Clarion-Williamsburg, road between; clay shows at several places, at some in considerable thickness, but of inferior quality.

Mechanicsville, $1 \frac{1}{2}$ miles northwest of, on road to Clarion; 2 feet exposed.

Mechanicsville, one-half mile east of, south of crossroads; inferior quality, black and knotty.

Mechanicsville, 1 mile east of, on road to Waterson station; 3 feet exposed.

Mechanicsville, 1 mile east of, on north and south road at top of hill; bed under light cover.

Clarion-Strattonville, road between; several exposures.

Strattonville, $1 \frac{1}{2}$ miles south of, and Rehoabeth Church, one-quarter mile west of; 2 feet exposed; inferior.

Strattonville, 2 miles northeast of, on road to Fisher, at top of rise; bed under light cover.

Strattonville, 2 miles northeast of, near schoolhouse; small showing, but clay apparently of excellent quality.

Clay workers will appreciate the difficulty of attempting to pronounce judgment on a clay from a field examination of an outcrop. Only such comments are made on the outcrops above noted as are obviously justified, the object being to call the attention of those who are interested to the occurrences of promising clay beds.

Upper Freeport horizon.-Present indications do not show that the flint clay from the upper Freeport horizon is important. Note was made, however, of the following occurrences of this clay:

Rimersburg, 1 mile north of, at road fork; good outcrop near top of hill.

Piollett, 1 mile west of; fragments at top of hill.

Frostburg, 2 miles southeast of, on ridge road; fragments.

Truittsburg, 2 miles northeast of; outcrop of inferior quality.

\section{COMMERCIAL DEVELOPMENT.}

At present there are three clay-working plants in the quadrangle, viz, the Canton Tile Hollow Brick Company, the Hawthorn Pottery Company, and the Sligo Fire Brick Company, the character of whose products has already been stated. In the future development of the clays of the quadrangle the flint clay from the Lower Kittanning horizon seems to offer the greatest possibilities. Although this clay is not equal in quality to the best flint clays on the market it nevertheless makes a fairly good fire brick: The writer does not know that experiments have been made in the use of plastic clay from the same horizon as a bond, but observation of outcrops indicates that if the clay were to be used on the spot the plastic clay accompanying the flint at most places would be sufficient, in quantity at least, to furnish the necessary bond. 
Coal and natural gas are available in nearly all parts of the region, affording efficient and cheap fuel. Prices of natural gas for commercial use, quoted to the writer, range from 8 to 22 cents per thousand feet. An idea of freight rates may be obtained from the following quotations from Sligo:

Sligo to Pittsburg, $\$ 1.40$ per ton for clay and $\$ 1.60$ for brick.

Sligo to Buffalo, $\$ 1.60$ per ton for both brick and clay. 


\section{CLAYS AND SHALES OF SOUTHWESTERN CAMBRIA COUNTY, PA. ${ }^{a}$}

By W. C. Phaten and Lawrence Martin.

\section{INTRODUCTION.}

Area.-The area here considered is the Johnstown quadrangle of the United States Geological Survey, comprising 228 square miles in southwest-central Pennsylvania. Though mostly in Cambria County, it includes small parts of Indiana, Westmoreland, and Somerset counties.

Geology.-The rocks that outcrop in this district are mostly of the Carboniferous system, but a few hundred feet (400土) of Devonian rocks are present. Of the Carboniferous rocks only those of the Pennsylvanian series are of interest, for, except the Pleistocene and later clays, all the valuable clay deposits seem to be confined to this series. As developed in this area the Pennsylvanian series comprises the Pottsville, the Allegheny, and perhaps all or nearly all of the Conemaugh formation-in all, about 1,200 feet of beds. These formations correspond to the Pottsville conglomerate or Millstone grit, the Lower Productive, and Lower Barren Coal Measures, respectively, of the Second Geological Survey of Pennsylvania.

THE CLAYS.

The clay materials of this region are flint clays, plastic clays (including some fire clays), and shales.

\section{GEOLOGICAL POSITION OF THE CLAYS.}

Flint clays are found at three and possibly more horizons. The highest flint clay occurs in the Conemaugh formation and varies in position in the Johnstown district from 50 to 100 feet above the Upper Freeport coal (known also as the "E," Coke Yard, "Fourfoot," and Lemon seam), and usually lies near the top of the Mahoning sandstone. In the Blacklick Creek district, west and southwest of Wehrum, a flint clay has been observed at many places in a similar position with reference to the Mahoning sandstone and is probably to be correlated with the flint clay occurring about Johnstown.

$a$ These notes are preliminary in nature. A more detailed account of the clay resources of the Johnstown quadrangle will be published later.

344 
In the Allegheny formation flint clay was observed in the northwest section of the area, in the valley of Mardis Run. It occurs about 25 feet below what is presumably the Upper Freeport coal, and hence may correspond with the Bolivar fire clay of the region. farther southwest.

The most important flint clay is that occurring at the Mercer horizon, in the Pottsville formation, in the South Fork district.

Plastic clays have been observed at many horizons in this region. At only a few places, however, is the position of the beds with reference to transportation and their thickness such as to make them of great economic importance. A few unimportant plastic clay beds have been observed in the Conemaugh formation. Many of the coals in the Allegheny formation are underlain by plastic clays. The clay below the " $\mathrm{E}$ " coal is at some places of workable thickness, though it is not comparable with that below the "B," or Lower" Kittanning, or Miller seam. Below the limestone bed associated with the Upper Kittanning coal (known also as the cement or " $\mathrm{C}$ " " coal) a deposit of clay was noted at some points about Johnstown. The plastic clay lying below the Miller coal is the most valuable in the region. It varies from 4 to 12 feet in thickness. This fire clay has been extensively exploited about Johnstown and to a less extent about South Fork. Along Blacklick Creek, in the northern part of the area, the clay at this horizon is of workable thickness, but, so far as known, has never been utilized.

The lowest plastic clay in this region is found at the Mercer horizon, though, as indicated above, a flint clay lies at this horizon at some places.

The valuable shales in this area appear to be confined chiefly to the Conemaugh formation, though important beds may occur in the Allegheny and Pottsville. In the Johnstown district valuable shale beds occur in the lower 300 feet of the Conemaugh formation and are worked near the city. The higher beds of this formation are exposed in the railroad cuts west of Wilmore, and the many beds of shale observed there indicate the presence of good brick-making material in the hills between Wilmore and Summerhill along the Pennsylvania Railroad. At the Mercer horizon also shales are associated with the coal and fire clay.

At the Bruce H. Campbell quarry, north of Sheridan, a clay that is associated with bowlders and is presumably of Pleistocene age is worked. Residual clays are so widely distributed in this region as hardly to merit detailed mention.

The clays and shales that are now worked will be described and the deposits not yet exploited will be noted, especially those that are situated near markets and lines of transportation. 


\section{JOHNSTOWN DISTRICT.}

Flint clay. - So far as known flint clay occurs persistently at only one horizon in the Johnstown district. This horizon lies very close to the top of the Mahoning sandstone, and in the immediate vicinity of the city is 50 to 80 feet above the horizon of the Coke Yard coal. Though fairly well distributed in favorable localities for easy exploitation, this clay is, so far as known, worked only by the Johnstown Pressed Brick Company at their plant on a hill east of the city. A section of the rocks in the hill will show the position of this clay and its relation to the underlying coal, which is at the top of the Allegheny formation.

Section of lower part of the Conemaugh formation in hill east. of Johnstown.

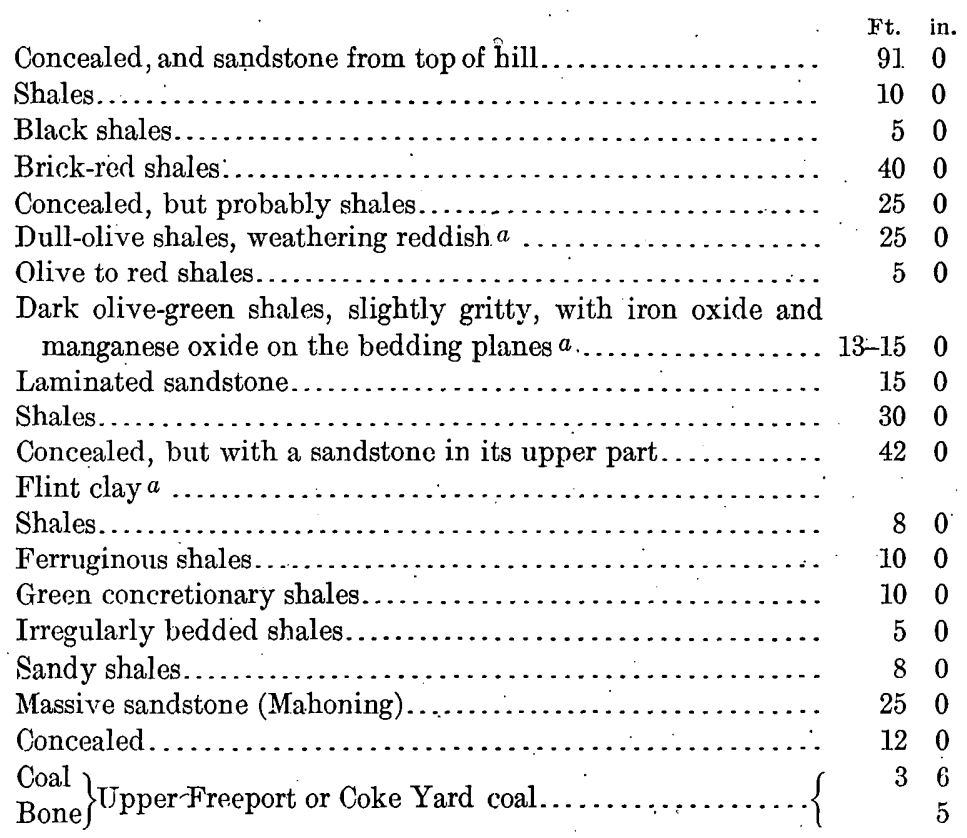

In Dale Borough, east of Johnstown, on the road ascending Shingle Run, 2 feet of flint clay were noted at this horizon. An old prospect hole was seen on this flint clay on the county road leading to Grandview Cemetery. On the road to Ferndale, a short distance north of the Citizens' Coal Company's Eighth Ward mine, an abundance. of flinty clay débris occurs above the road near the top of the massive Mahoning sandstone. In the hill above the Baltimore and Ohio tunnel, east of Island Park, some flint clay was observed on the new county road about 40 feet above the Upper Freeport coal and near 
the top of the Mahoning sandstone. Northwest of Johnstown, in the valley of Laurel Rin, a short distance east of the old coke yard, from which the Upper Freeport coal gets its local name, this flint clay is exposed, indicating a possible continuity of the bed as far west as this point. Northwest of Johnstown, on the road ascending Pleasant Hill from the valley of the Conemaugh River, a flint clay occurs about 110 feet above the Upper Freeport coal and 10 feet below a smaller seam of coal. This latter coal may possibly be higher than the seam 70 feet above the Upper Freeport at the Baltimore. and Ohio tunnel. If so, this flint clay of Pleasant Hill is higher than that previously described.

On the headwaters of Mill Creek and Dalton Run and near the south edge of the area west of Stony Creek, a fairly perşistent flint clay was observed well toward the base of the Conemaugh formation. These occurrences are too far from lines of transportation to be of great economic importance at the present time.

It should be added that the occurrences noted above are largely roadside outcrops at which it is impossible to determine the exact thickness and nature of the clays. Only careful prospecting can determine these points, but the fact that one of the flint clays is being successfully used at one point is significant.

Plastic clay.-The flint clay above the Mahoning sandstone assumes a plastic phase at places in the Johnstown district. Most of the valuable plastic clay in this region, however, occurs in the Lower Productive Measures or Allegheny formation. At a few places a clay bed of workable thickness lies below the Upper Freeport coal, in connection with which it might be mined. At the Cyrus Shepard mine, leased by L: J. Mitchell, east of Franklin, 2 feet $4 \frac{1}{2}$ inches of fire clay were measured, but the bed may not be persistent. A clay bed which promises to be of some importance underlies the limestone - below the Upper Kittanning or "C" coal seam. This clay has been developed to some extent, though so fär as the writers are aware it is not now worked. According to T. T. Morrell ${ }^{a}$ it has the following composition:

Anatysis of clay near Johnstown, Pa.

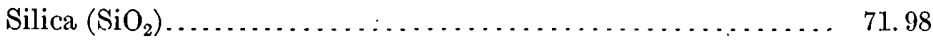

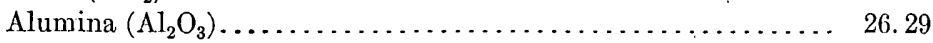

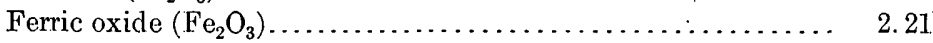

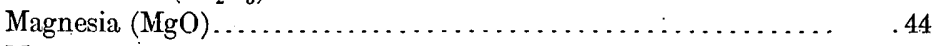

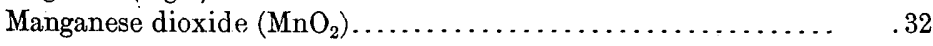

101. 34

a Second Geol. Survey Pennsylvania, Rept. H2, p. 148. 
The most valuable plastic clay in the Allegheny formation is that underlying the Miller coal seam. Many of the mines operating this coal about Johnstown produce, as well, considerable amounts of this clay. This clay bed in this district generally ranges from 3 to 6 feet in thickness, but may possibly be thicker locally. It usually underlies the lower bench of the Miller seam, from which it is separated by a few inches of shale or, in the absence of this lower bench, it occurs below the main coal itself, being separated from it by 3 to 4 inches of bone or shale. It is a light-drab clay, not very hard, of irregular fracture, greasy to the touch, and slakes on exposure to the weather. Its composition is indicated by the following analyses:

Analyses of ciay unaerlying the Miller seam.

\begin{tabular}{|c|c|c|c|c|}
\hline & 1. & 2. & 3. & 4. \\
\hline 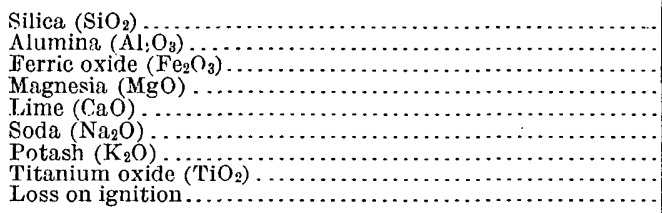 & $\begin{array}{r}65.90 \\
20.30 \\
a 1.60 \\
.66 \\
.09 \\
.34 \\
2.98 \\
1.20 \\
6.50\end{array}$ & $\begin{array}{r}66.40 \\
19.80 \\
a 1.68 \\
.61 \\
.10 \\
.30 \\
3.24 \\
1.00 \\
6.40\end{array}$ & $\begin{array}{r}53.10 \\
27.80 \\
a 3.08 \\
.60 \\
.22 \\
.48 \\
3.58 \\
1.20 \\
10.20\end{array}$ & 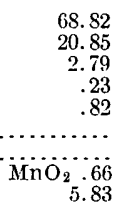 \\
\hline & 99.57 & 99.53 & 100.26 & 100.00 \\
\hline
\end{tabular}

a Total iron caleulated as $\mathrm{Fe}_{2} \mathrm{O}_{3}$.

1. Citizens' Coal Company's Green Fill mine, Johnstown, Pa.; F. C. Sullivan, analyst.

2. A. J. Haws \& Sons (Limited) mine, near the stone bridge, Johnstown, Pa.; F. C. Sullivan, analyst. 3. Seward Coal Company's mine, Seward, Westmoreland County, Pa.; E. C. Sullivan, analyst.

4. Clay-underlying the Miller seam at Johnstown; T. T. Morrell, analyst, Second Geol. Survey Pennsylvania, Rept. HH, p. 148 .

This clay is worked about Johnstown by W. J. Williams at Kernville; by the Citizens' Coal Company at Green Hill; by A. J. Haws \& Sons (Limited), both at Coopersdale and near the famous stone bridge, and by Robertson \& Griffin on St. Clairs Run; at each place in connection with the overlying coal. Though not always worked, this clay is present at many places in this district in workable thickness.

Nearly all the product of the Johnstown mines is used at local brick plants where it is mixed with flint clay from the Mercer horizon, shipped from South Fork and from other points. When thus mixed in proper amount it forms a suitable bond in a clay that is used in the manufacture of high-grade refractory products and bricks, for blast furnace and open-hearth work, and in making sleeves, nozzles, tuyères, and other articles that are exposed to high temperatures.

The lowest plastic clay in the Johnstown district is associated with the Mercer coal, but is not exposed in the immediate vicinity of the city. In the hills lying east of Stony Creek, south of Kring, on the Baltimore and Ohio Railroad, this horizon has been prospected and some clay and shales have been found, but they have never been worked. Flint clay was not seen at any of the old prospect pits. 
North of Sheridan, at the quarry of Bruce H. Campbell, the following section was measured, showing 6 feet, or possibly more, of clay below the Mercer coal:

Section of Mercer coal and shales at Bruce H. Campbell quarry, north of Sheridan.

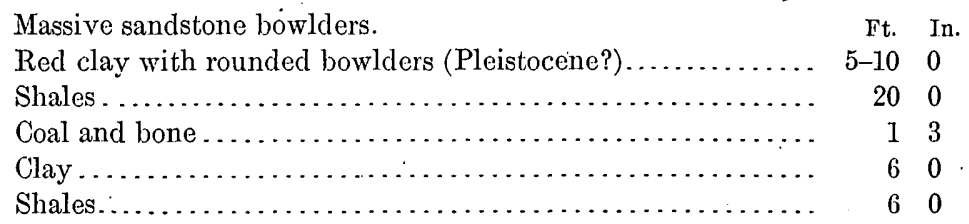

This clay has never been worked, but it is apparently of good grade.

Shales.-It has been remarked that the most important shale horizons about Johnstown are confined to the lower 300 feet of the Conemaugh formation. 'The section given on page 346 shows the character of the lower 400 feet of beds in this group of rocks in the hill east of the city. From about 50 feet above the top of the Coke Yard coal to the top of the hill numerous promising beds of shale are exposed. Most of the shale group lying between 165 feet and 210 feet above the Coke Yard coal is being worked by the Johnstown Pressed Brick Company into a good grade of building brick. In the hill north of the city the Cambria Steel Company has quarried shales lying 100 feet above the Coke Yard coal seam and has utilized them in connection with the overlying surface clays, in the manufacture of red building bricks of good quality.

The geological structure of the region immediately around the city is such that the beds lie fairly flat, and the lower few hundred feet of the Conemaugh formation are exposed. Sections obtained in the hills around the city and along the Pennsylvania Railroad to the west indicate that the lower part of this formation is of prevailingly shaly character, comparable with that seen in the hill to the east. It is therefore probable that a great deal of brickmaking material exists in these hills which has never been tested. Though all this shale may not be of the grade of that worked by the Johnstown Pressed Brick Company some of it probably is, and much of it may be suitable for paving brick, sewer pipe, fireproofing of various sorts, and for other rough material. All the shale in the hills about the city and to the west is fairly accessible to transportation, and cheap fuel is assured by the presence of valuable coal beds 300 feet or more below.

The lowest promising shale horizon in this district is associated with the Mercer coal. The prospect pits on the Baltimore and Ohio Railroad south of Krings station show the presence of dark shales at this horizon. At points north of Sheridan the Mercer shales are.

Bull. $315-07-23$ 
thick, and are worked in connection with the overlying Pleistocene clays at the quarry of Bruce H. Campbell. The section measured at this quarry, given on page 349 ; shows 20 feet of workable shales overlying the coal. They are dark brown and drab in color, somewhat sandy and concretionary. This shale is mixed with the overlying clay, and the mixture is used in making a buff or red building brick, the color depending on the proportions of shale and clay used. The beds worked at this quarry rise abruptly toward the west at a rate that carries the Mercer horizon over the tops of the hills to the west.

\section{SOUTH FORK DISTRICT.}

Flint clay.-A band of clay that occurs in the Pottsville formation in the South Fork district has been worked at points south of the Pennsylvania Railroad from South Fork westward, beyond Mineral Point, and also at a few places north of the railroad. In this district this clay is characterized by a persistent flinty streak. This clay is present in the hills along Conemaugh River, in an area extending as far west as a point about 1 mile east of Conemaugh station. The outcrop is continuous, except where the local dips and change in direction of the river carry it below drainage. The flinty clay may not be always present between Mineral Point and Conemaugh. For example, the clay observed at this horizon in the tunnel of the old Portage Railroad is not particularly flinty in character. From Mineral Point to South Fork, however, the flinty character is persistent.

This flint clay is now worked by the Garfield Fire Clay Company, near the viaduct, and by J. H. Wickes and the South Fork Fire Brick Company, west of South Fork. The following section was measured at Mr. Wickes's mine:

Section of fire clay. at J. H. Wickes's mine, South Fork.

Heavy sandstone roof.

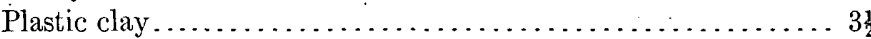

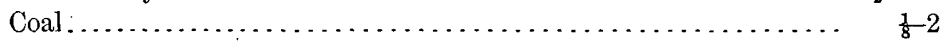

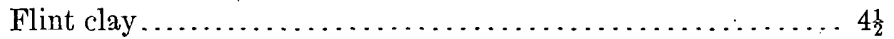

Sandstone.

This clay is also worked by the Page-Reigard Mining Company near Mineral Point and at South Fork, but in July, 1904, the mine at South Fork was shut down. It is reported that the plastic clay is persistent, but that the thickness of the flint clay is variable, dwindling to 14 inches in a northeast-southwest zone. A specimen of this flint clay from the central band of the bed worked near the viaduct some years ago was analyzed by T. T. Morrell, of Johnstown, with the following results: 
Analysis of flint clay from the Mercer horizon near the viaduct, Cambria County, Pa.a

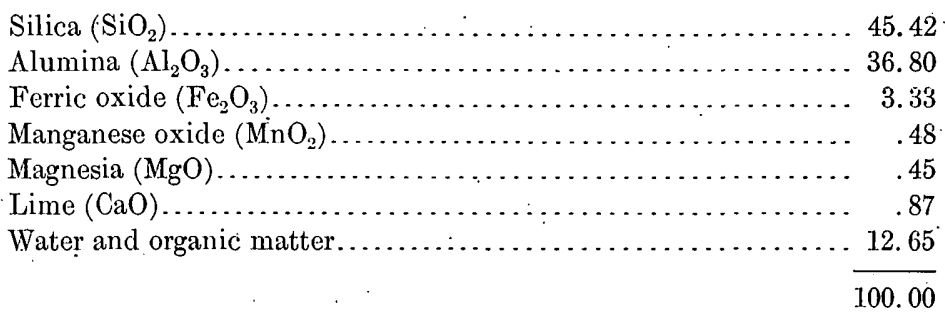

This clay is smooth, hard, compact, light to dark gray in color, and breaks with a conchoidal fracture. It burns to a straw-yellow color. The analysis, as far as it goes, indicates a fairly high-grade material, with perhaps a little too much iron. The presence or absence of alkalies was unfortunately not determined.

The clay mined at South Fork is in part shipped to Johnstown and in part mixed with plastic clay from the Lower Kittanning seam and worked up at the local brick plant. The refractory character of some of the products of this flint clay has been tested at the plant of the Cambria Steel Company at Johnstown and they have proved highly satisfactory.

Plastic clay.-About South Fork a plastic clay has been observed at some places near the top of the Mahoning sandstone. Its position corresponds with that of the band of flint clay in the Johnstown district. In the region about South Fork it has been observed at but few places and is of doubtful value. The clay below the Upper Freeport (Lemon) coal seam is fairly thick in this region, but is not worked at present. At O. M. Stineman's mine No. 3, 2 feet 3 inches of clay were measured below this coal, which may be worked at some future time in connection with the coal. This clay is not comparable in thickness with that directly underlying the Miller coal seam, which about South Fork, as near Johnstown, is the most important plastic clay in the Allegheny formation. The plastic clay associated with the Miller coal seam is usually workable, at some places having a thickness of 6 to 8 feet, though averaging about 3 to 4 feet of workable clay of good grade. A brief note on the character of this clay will be found in the description of its occurrence in the Johnstown district, where analyses also are given. There is every reason to suppose that in this district it is of the same quality as the clay mined about Johnstown. Most of the clay product of the mines about South Fork is mined in connection with the coal and is used almost entirely at the local brick plant.

Shate.-So far as known the shales in the South Fork district have not been utilized. In the two large cuts west of the town of Wilmore, on the main line of the Pennsylvania Railroad, shale beds are exposed 
that vary in position from 400 to 675 feet above the Upper Freeport coal. These beds contain many promising shales, which are found in the surrounding hills, conveniently situated with respect to transportation. Their appearance indicates that they may be adapted to the manufacture of paving brick and other materials that require only an inferior grade of clay or shale. To determine their fitness for any purpose, however, practical tests must be made. In a recent cut opposite Ehrenfeld station, along the new county road, a bed of shale 50 to 60 feet thick, lying 60 feet above the Upper Freeport coal, also appears to be promising.

\section{BLACKLICK CREEK DISTRICT.}

The South Fork of Blacklick Creek flows along the northern edge of the Johnstown quadrangle. It is joined by the North Fork a short distance west of Vintondale and then flows westward beyond the limits of the area. Deposits of flint and plastic clay are found in the adjacent hills along the creek, and although many of these are conveniently situated with respect to lines of transportation, the demand has not yet been sufficient to justify their exploitation.

Flint clay.-The flint clay in the Blacklick Creek district occurs at two horizons. The higher flint clay is found in the lower part of the Conemaugh formation above what is thought to be the equivalent of the Mahoning sandstone and a few feet below a small coal bed, possibly the Gallitzin coal. This flint clay has been observed in many places north, west, and south of Wehrum, but the rise of the beds toward the east causes a gradual increase in its distance from the valley and from transportation facilities and finally its complete absence from the hills. West of Wehrum, however, both north and south of Blacklick Creek, it occurs at many points, having the unusual thickness of 7 to 8 feet in places. It is a typical flint clay in appearance, though its content of iron oxide is apparently very high. A sample collected from a roadside exposure west of Dilltown gave the following analysis:

Partial analysis of flint clay from a natural exposure west of Dilltown.

[E. C. Sullivan, analyst.]

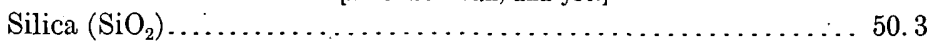

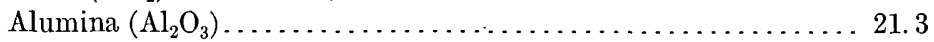

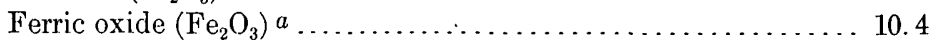

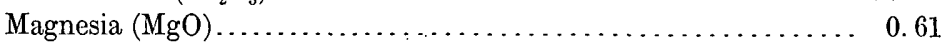

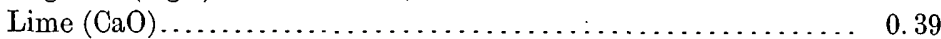

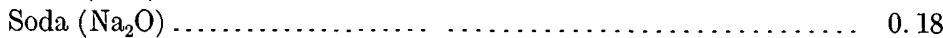

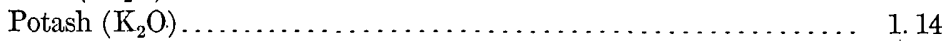

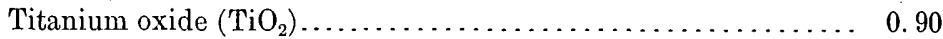

Loss on ignition ................................... 12.00

97.22 
The percentage of fluxing materials, principally iron oxide, indicated in this analysis, is so high as to prohibit its practical use. A lower flint clay, lying a few feet below what may prove to be the Upper Freeport coal, was seen at a few places in the valley of Mardis Run, near the northwestern edge of the area. This clay may correspond with the Bolivar clay of the region to the southwest. Two feet of clay were seen at one point on the outcrop and the bed may possibly be thicker. This clay is rather remote from transportation.

Plastic clay.-The coal that is being extensively worked in the valley of Blacklick Creek is regarded as the equivalent of the Lower Kittanning, Miller, or "B" seam of the Johnstown and South Fork districts. In the Blacklick Creek district, as well as along Conemaugh River, this coal is underlain by a promising clay bed. This clay is not exploited at present, and no certain measurement of its thickness was obtained. At many of the mines 2 feet or more of promising clay were seen, comparable, in appearance at least, with that in the Johnstown district.

\section{MISCELLANEOUS OCCURRENCES OF CLAY.}

Along the western flank of Laurel Ridge, near the line of the Pennsylvania Railroad, the Miller coal seam has been opened at a few places and the clay underlying it shows in workable thickness. At the coal mine of the Johnstown Coal Company more than 2 feet of clay were seen, and near Seward, beyond the western limits of this area, 12 feet of clay occur in this same position, 6 of which are worked by the Seward Brick Company. ${ }^{a}$

Along the southern edge of this area, at Scalp Level and Windber, where the Miller coal seam is worked on a large scale by the BerwindWhite Coal Mining Company, sandy clay was observed below the Miller coal seam at Eureka mine No. 37.

\section{PRODUĆTION.}

The firms named below are engaged in the brick and clay industry in this area. In addition, coal companies mining the Miller coal seam about Johnstown and South Fork may produce small quantities of the underlying clay for use in the local brick plants.

Clay miners.

Page-Reigard Mining Company, flint clay, Mineral Point.

W..J. Williams, plastic clay, Kernville.

Citizens' Coal Company, plastic clay, Green Hill mine, Johnstown.

Robertson \& Griffith, plastic clay, St. Clairs Rü̈, Morrellville.

$a$ For an analysis of the clay underlying the coal mined at Seward, see p. 348 . 


\section{Manufacturers of fire brick.}

Harbison-Walker Company, Cambria City.

A. J. Haws \& Sons (Limited), Johnstown and Coopersdale.

Hiram Swank Sons, Johnstown.

South Fork Fire Brick Company, South Fork.

Manufacturers of buildina brick.

Cambria Steel Company, Johnstown.

Bruce H. Campbell Brick Company, Sheridan.

Johnstown Pressed Brick Company, Johnstown.

The following table gives a fair idea of the value of the brick industry in this region during the past two years:

Quantities and values of clay products in region about Johnstown, Pa., in 1904 and 1905.

\begin{tabular}{|c|c|c|c|c|}
\hline \multirow[b]{2}{*}{. } & \multicolumn{2}{|c|}{1904.} & \multicolumn{2}{|l|}{1905.} \\
\hline & Amount. & Value. & Amount. & Value. \\
\hline 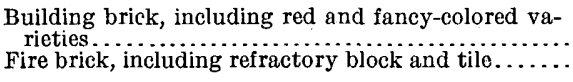 & $\begin{array}{r}6,946,000 \\
26,024,000\end{array}$ & $\begin{array}{l}\$ 50,772 \\
482,647\end{array}$ & $\begin{array}{l}12,549,000 \\
33,648,000\end{array}$ & $\begin{array}{l}\$ 88,444 \\
600 ; 798\end{array}$ \\
\hline . & $32,970,000$ & 533,419 & $46,197,000$ & 689,242 \\
\hline
\end{tabular}




\section{SURVEY PUBLICATIONS ON CLAYS, FULLER'S EAR'TH, ETC.}

Ina ddition to the papers listed below, references to clays will be found in the publications listed under the head of "Cements," on pages $245-246$.

Ashley, G. H. Notes on clays and shales in central Pennsylvania. In Bulletin No. 285 , pp. $442-444.1906$.

Bastin, E. S. . Clays of the Penobscot Bay region, Maine. In Bulletin No. 285, pp. 428-431. 1906.

Branner, J. C. Bibliography of clays and the ceramic arts. Bulletin No. 143. 114 pp. 1896.

Criner, A. F. Clays of western Kentucky and Tennessee. In Bulletin No. 285, pp. 417-427. 1906.

Ecked, E. C. Stoneware and brick clays of western Tennessee and northwestern Mississippi. In Bulletin No. 213, pp. 382-391. 1903.

- Clays of Garland County, Ark. In Bulletin No. 285, pp. 407-411. 1906.

Fisher, C. A. The bentonite deposits of Wyoming. In Bulletin No. 260, pp. 559-563. 1905.

Fuller, M. I. Clays of Cape Cod, Massachusetts. In Bulletin No.285, pp. 432-441. 1906.

Golding, W. Flint and feldspar. In Seventeenth Ann. Rept., pt. 3, pp. 838-841. 1896.

Hrul, R. T. Clay materials of the United States. In Mineral Resources U. S. for 1891, pp. 474-528. 1892.

— Glay materials of the United States. In Mineral Resources U. S. for 1892; pp. 712-738. 1893.

Landes, H. The clay deposits of Washington. In Bulletin No. 260, pp. 550-558. 1.905.

Phalen, W. C. Clay resources of northeastern Kentucky. In Bulletin No. 285, pp. 412-416. 1906.

RiEs; H. Technology of the clay industry. In Sixteenth Ann. Rept., pt. 4, pp. 523-575. 1895.

- The pottery industry of the United States. In Seventeenth Ann. Rept., pt. 3, pp. 842-880. 1896.

The clays of the United States east of the Mississippi River. Professional Paper No. 11, 298 pp. 1903.

Schrader, F. C., and Haworth, E. Clay industries of the Independence quadrangle, Kansas. In Bulletin No. 260, pp. 546-549. 1905.

Shaler, N. S., Woodworth, J. B., and Marbut, C. F. The glacial brick clays of Rhode Island and southeastern Massachusetts. In Seventeenth Ann. Rept., pt. 1, pp. 957-1004. 1896.

Stebenthat, C. E. Bentonite of the Laramie basin, Wyoming. In Bulletin No. 285, pp. 445-447. 1906.

Vaughan, T. W. Fuller's earth deposits of Florida and Georgia. In Bulletin No. 213, pp. 392-399. 1903.

Wimber, F. A. Clays of the United States. In Mineral Resources U. S. for 1882, pp. $465-475.1883$.

711. 1885.

Woolsey, I. H. Clays of the Ohio Valley in Pennsylvania. In Bulletin No. 225, pp. 463-480. 1904 . 